\title{
Estudo do processo de construção da Agenda 21 nas escolas da Diretoria de Ensino de Jundiaí -SP
}

Claudete Aparecida Formis

\begin{abstract}
Dissertação apresentada ao Programa de Pós-Graduação em Saúde Pública da Faculdade de Saúde Pública da Universidade de São Paulo para obtenção do título de Mestre em Saúde Pública.
\end{abstract}

Área de Concentração: Serviços de Saúde Pública

Orientadora:

Profa. Dra. Maria Cecília Focesi Pelicioni

São Paulo

2006 
É expressamente proibida a comercialização deste documento tanto na sua forma impressa como eletrônica. Sua reprodução total ou parcial é permitida exclusivamente para fins acadêmicos e científicos, desde que na reprodução figure a identificação do autor, título, instituição e ano da dissertação. 
"À todos que com seu exemplo, me ensinaram o valor de construir e construir-se, re-significando a vida." 


\section{AGRADECIMENTOS}

Aos meus pais, Leonor e Concílio, que nos deixaram o exemplo de dignidade, perseverança e retidão.

Às minhas filhas Maíra, Marina e Marília, pelo amor, carinho e cumplicidade na alegria de viver.

Aos meus irmãos Arlete, Marcos e Marcel, aos meus cunhados-irmãos Gerson, Patrícia e Débora, e aos meus sobrinhos Júlia, Arthur e Pedro por serem uma família maravilhosa e o meu porto seguro de todas as horas.

À Profa . Cecília, orientadora, amiga e mestra, pela oportunidade, dedicação, competência e ética com que me conduziu à construção deste trabalho, que em última instância é uma auto-descoberta e reconstrução.

Aos professores Arlindo Philippi Jr e Marcos Reigota pela preciosa orientação na condução deste trabalho.

Às amigas Regina Célia e Regina Mostério por serem referenciais na arte de ensinar.

Aos amigos da EE Prof. Francisco Napoleão Maia pelo apoio, incentivo, e profissionalismo com que constroem diariamente a escola pública.

Aos professores da DE Jundiaí pelo apoio, incentivo e disponibilidade em todo o processo de construção desse trabalho; em especial a Zezé, Iracema, e às Supervisoras Ana Maria e Jussara.

À amiga Renata Ferraz de Toledo pela sua competência e por poder contar com o seu apoio sempre.

Aos professores que pacientemente se dispuseram a participar do trabalho de pesquisa, sem o que este trabalho não teria se concretizado. 
Ao Sr. Luis Carlos Rosa, Diretor da Divisão de Meio Ambiente da cidade de Louveira pelo seu exemplo de gestão voltada à sustentabilidade.

Aos meus queridos alunos que compartilharam deste trabalho e espero poder contribuir na formação por um mundo mais justo e sustentável. 


\section{Resumo}

Formis CA. Estudo do processo de construção da Agenda 21 nas Escolas da Diretoria de Ensino de Jundiaí [Dissertação de Mestrado]. São Paulo (BR): Faculdade de Saúde Pública da Universidade de São Paulo; 2006.

Introdução. Estudo do processo de construção da Agenda 21 nas escolas públicas estaduais da Diretoria de Ensino de Jundiaí-SP, a partir da proposta pedagógica "Água Hoje e Sempre: Consumo Sustentável". A educação ambiental como instrumento na formação da cidadania no ensino formal. Objetivo. Identificar e registrar os conhecimentos e práticas dos professores sobre as questões ambientais; descrever as representações sociais dos educadores sobre meio ambiente e Agenda 21; analisar as transformações ocorridas nas escolas e propor encaminhamentos que possam colaborar com a construção da Agenda 21 Escolar. Metodologia. Pesquisa qualitativa, com utilização de três instrumentos para levantamento de dados: grupofocal, entrevista e análise documental. A análise dos resultados foi feita por triangulação. Resultados. Para a maioria dos professores a representação social sobre meio ambiente continua naturalista. Os docentes de uma maneira geral não conheciam as propostas da Agenda 21 Global. Os projetos e trabalhos apresentados sobre meio ambiente deram destaque para os temas: água, lixo, horta e saúde. Os projetos foram realizados de forma multidisciplinar e não interdisciplinar. As escolas do município de Louveira apresentaram resultados mais positivos por relacionarem a prática pedagógica ao espaço local de forma crítica e propositiva. Conclusões. É necessário que se implementem cursos de capacitação em educação ambiental para todas as disciplinas, a fim de subsidiar a formação do professor do ponto de vista teórico, metodológico e prático possibilitando subsidiar propostas pedagógicas voltadas para a sustentabilidade.

Descritores. Agenda 21 na Escola. Educação Ambiental. Formação de professor. Sustentabilidade. Representação Social. 


\begin{abstract}
Formis CA. Study of the Agenda 21's development process in schools at the Teaching Direction in Jundiaí [Dissertation]. São Paulo (BR): Faculdade de Saúde Pública da Universidade de São Paulo; 2006.

Introduction. The study of the Agenda 21's development process in state public schools belonging to the Teaching Direction in Jundiaí has its starting point at the pedagogical proposal "Água Hoje e Sempre: Consumo Sustentável". The Environmental Education as a tool in building the citizenship in formal education. Objective. To identify and register teachers' know-how about and ability to deal with environmental issues; describe the environment and the Agenda 21's social representation for educators; analyse the changes that took place in schools and suggest ways to improve the Agenda 21's development process. Methodology. Qualitative research was carried out by using three instruments to collect data: focal-group, interview and documental analysis. The results were analysed according to the triangulation method. Results. For most educators the environment's social impact remains naturalist. Teachers in general weren't aware of the Agenda 21's proposals. The projects and papers about the environment that were presented had their focus on topics like: water, garbage, planting and health. The projects were conceived in a multidisciplinary rather than in an interdisciplinary way. The schools in Louveira city achieved positive results due to critical and propositive relation made between the pedagogical practices and the local space. Conclusions. It is important that environmental education qualifying courses on all school subjects be implemented so as to assist the teacher's education on the theoretical, methodological and practical point of view enabling the support of pedagogical proposals headed for the sustainability.
\end{abstract}

Key words. Agenda 21. Environmental Education. Teacher's Education. Sustainability. Social Representation. 


\section{ÍNDICE}

1 INTRODUÇÃO

1.1 A SOCIEDADE PÓS-MODERNA E A TRANSIÇÃO PARADIGMÁTICA

1.1.1 A busca de novos paradigmas

1.2 A EDUCAÇÃO AMBIENTAL E POLÍTICAS PÚBLICAS

1.2.1 Encontros internacionais

1.2.2 Educação ambiental no ensino formal 28

1.2.3 Educação e a sustentabilidade 36

1.3 AGENDA 21 COMO INSTRUMENTO DE GESTÃO 38

1.3.1 Agenda 21 Brasileira 41

1.3.2 Agenda 21 Local 43

1.4 EDUCAÇÃO E AGENDA 21

1.4.1 Ensino Formal e Agenda 21 Global 45

1.4.2 Agenda 21 Escolar 48

1.5 A REGIÃO DE JUNDIAÍ

2 OBJETIVOS 56

3 MÉTODOLOGIA 57

3.1 Metodologia qualitativa $\quad 57$

3.2 População alvo 58

3.3 Instrumentos de pesquisa 59

3.3.1 Grupo focal 59

3.3.2 Análise Documental $\quad 60$

3.3.3 Entrevista 60

4 RESULTADOS E DISCUSSÃO 62

4.1 As escolas de Jundiaí $\quad 64$

4.2 As escolas de Louveira 90

5 CONCLUSÕES 105

6 RECOMENDAÇÕES E SUGESTÕES 109

7 REFERÊNCIAS 110 


\section{ANEXOS}

Anexo 1 - Escolas Estaduais do Município de Jundiaí 1

Anexo 2 - Escolas Estaduais do Município de Louveira 3

Anexo 3 - Roteiro para grupo focal 4

Anexo 4 - Termo de consentimento livre e esclarecido - grupo focal 5

Anexo 5 - Termo de consentimento livre e esclarecido -documentos 6

Anexo 6 - Fotos da Exposição - 1ํ EMESA - Louveira 7

Anexo 7 - Fotos da Exposição - 1ํㅡㄹㅗ - Louveira 8

Anexo 8 - Mapa da Área de estudo - Região de Jundiaí 10 


\section{Siglas Utilizadas}

$\begin{array}{ll}\text { APA } & \text { Área de Proteção Ambiental } \\ \text { ATP } & \text { Assistente Técnico Pedagógico } \\ \text { CENP } & \text { Coordenadoria de Estudos e Normas Pedagógicas } \\ \text { CNUMAD } & \begin{array}{l}\text { Conferência das Nações Unidas sobre Meio Ambiente e } \\ \text { Desenvolvimento }\end{array} \\ \text { DE } & \text { Diretoria de Ensino } \\ \text { EA } & \text { Educação Ambiental } \\ \text { HTPC } & \text { Hora Trabalho Pedagógico Coletivo } \\ \text { IUCN } & \begin{array}{l}\text { International Union for Conservation of Nature and Natural } \\ \text { Resources (União Internacional para a Conservação da }\end{array} \\ \text { MCT } & \text { Natureza) } \\ \text { MEC } & \text { Ministério de Ciência e Tecnologia } \\ \text { MMA } & \text { Ministério de Educação e Cultura } \\ \text { ONU } & \text { Ministério do Meio Ambiente } \\ \text { OP } & \text { Organização das Nações Unidas } \\ \text { PCP } & \text { Oficina Pedagógica } \\ \text { PNEA } & \text { Professor Coordenador Pedagógico } \\ \text { PNUD } & \text { Política Nacional de Educação Ambiental } \\ \text { SEE } & \text { Programa das Nações Unidas para o Desenvolvimento } \\ \text { SMA } & \text { Secretaria de Educação do Estado } \\ \text { UE } & \text { Secretaria do Meio Ambiente } \\ \text { Unidade Escolar }\end{array}$




\section{INTRODUÇÃO}

\subsection{A SOCIEDADE PÓS-MODERNA E A TRANSIÇÃO PARADIGMÁTICA}

\subsubsection{A busca de novos paradigmas}

O período de 1950 a 1975, chamado de a "idade do ouro", foi o palco da mudança social mais espetacular, rápida, abrangente, profunda e global já registrada na história (HOBSBAUN, 1995) configurando-se num período de extremos resultante do direcionamento do poder econômico e do poder político para a promoção do desenvolvimento social e econômico.

As dificuldades do período do pós $2^{\mathrm{a}}$ guerra mundial foram decisivas para participação do poder político de forma intervencionista na economia e na promoção de políticas sociais. $O$ crescimento econômico calcado no desenvolvimento industrial e urbano foi a principal estratégia utilizada para a superação da crise mundial nos países do primeiro mundo e para a diminuição do abismo existente entre esses e os países do segundo e terceiro mundo (nomenclatura do período utilizada para a divisão política e econômica entre os países).

O desenvolvimento econômico aconteceu de maneira desigual entre os países, e o que deveria reduzir a distância entre eles acabou por acentuálas, como pode ser mensurado por índices econômicos elaborados e divulgados por instituições como Banco Mundial e o PNUD (Programa das Nações Unidas para o Desenvolvimento) entre outras. A crescente concentração de capital, da produção agrícola, tecnológica, científica e as trocas comerciais, nunca foram tão discrepantes entre os países. 
Aos países subdesenvolvidos coube o fornecimento de matérias primas, o pagamento de altas taxas de juros referentes a empréstimos de fundos internacionais para o financiamento do desenvolvimento econômico e um grande ônus social.

$\mathrm{Na}$ década de 1990 o Programa das Nações Unidas para o Desenvolvimento - PNUD criou o Índice de Desenvolvimento Humano (IDH) para comparar as condições de vida dos países baseando-se em três indicadores: expectativa de vida, que é a estimativa de anos que uma criança deve viver segundo as condições sócio-econômicas do local onde nasceu; a taxa de alfabetização, considerando o número de pessoas alfabetizadas com quinze anos ou mais; e a distribuição de renda. Ainda que deva se considerar a formação cultural de cada sociedade para a definição do padrão ideal de consumo e condições sociais, e que isso acarrete dificuldades no estabelecimento de limites válidos para todos os lugares e países, a divulgação do relatório permitiu fazer comparações entre os países e entre diferentes espaços mundiais.

Desenvolvimento Humano pode ser definido como um processo abrangente de expansão do exercício do direito de escolhas individuais em diversas áreas: econômica, política, social ou cultural. Algumas dessas escolhas são básicas para a vida humana. As opções por uma vida longa e saudável, ou por adquirir conhecimento, ou por um padrão de vida decente são fundamentais para os seres humanos (...) (PNUD, 1998, p.35).

O relatório apresentou dados que demonstram as discrepâncias e a fragilidade sócio-econômica dos países que não conseguiram ingressar nos programas de desenvolvimento. Os resultados do IDH demonstraram que as estratégias de desenvolvimento econômico não acarretaram o desenvolvimento social igualitário nem a distribuição de recursos de forma eqüitativa entre os povos. Ao contrário houve uma concentração acentuada de disponibilidade de recursos materiais, monetários e tecnológicos nos países desenvolvidos e grandes carências que condenam a redução de potencialidades e condições dignas de qualidade de vida. Anualmente, o 
PNUD divulga os relatórios sobre a evolução do IDH e outros como o Índice de Pobreza Humana - IPH que mede a falta de boas condições de vida e os problemas que ainda persistem; e o Índice de Desenvolvimento Ajustado ao Gênero - IDG que leva em consideração os mesmos indicadores do IDH, porém comparando as diferenças existentes entre os gêneros como forma de detectar exclusões e privações de acesso a oportunidades, serviços e direitos para o sexo feminino.

A seguir, no Quadro I são apresentados alguns dados que sintetizam as condições de vida da década de 1960 até a de 1990, segundo o PNUD (1990).

Quadro 1. Panorama do desenvolvimento humano mundial - 1960 a 1990

\begin{tabular}{|c|c|}
\hline Progresso humano & Carências Humanas \\
\hline \multicolumn{2}{|c|}{ Expectativa de vida } \\
\hline $\begin{array}{l}\text { - A expectativa de vida média do Sul } \\
\text { aumentou em um terço entre } 1960 \text { e } \\
1987 \text { e representa agora } 80 \% \text { da } \\
\text { média do Norte. }\end{array}$ & $\begin{array}{l}\text { - A expectativa de vida média no Sul } \\
\text { ainda é } 12 \text { anos menor que no Norte. }\end{array}$ \\
\hline \multicolumn{2}{|c|}{ Educação } \\
\hline 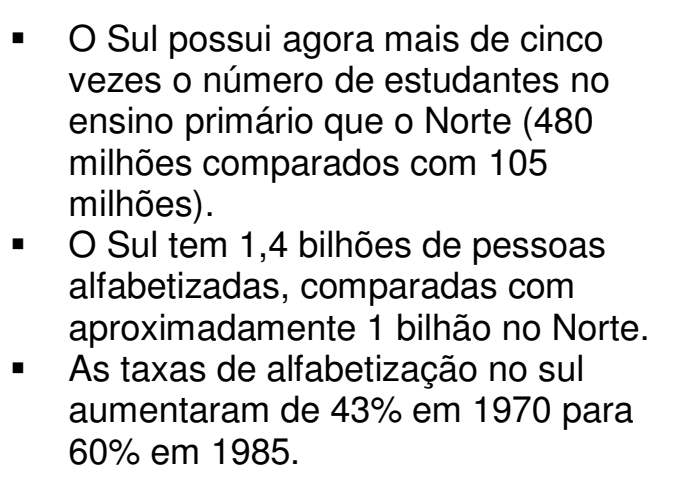 & $\begin{array}{l}\text { - No Sul ainda há aproximadamente } \\
100 \text { milhões de crianças em idade } \\
\text { escolar primária não freqüentando } \\
\text { escolas. } \\
\text { - Aproximadamente } 900 \text { milhões de } \\
\text { adultos no Sul são analfabetos. } \\
\text { - As taxas de alfabetização ainda são } \\
\text { de apenas } 41 \% \text { no sul da Ásia e } 48 \% \\
\text { na África Sub Saariana. }\end{array}$ \\
\hline \multicolumn{2}{|c|}{ Renda } \\
\hline $\begin{array}{l}\text { - A renda per capita média nos países } \\
\text { em desenvolvimento aumentou } \\
\text { aproximadamente } 3 \% \text { entre } 1965 \text { e } \\
1980 \text {. }\end{array}$ & $\begin{array}{l}\text { - Mais de } 1 \text { bilhão de pessoas ainda } \\
\text { vivem na pobreza absoluta. } \\
\text { Nos anos } 80 \text { a renda per capita diminuiu } \\
\text { 2,4\% por ano na África Sub Saariana e } \\
\text { 0,7\% por ano na América Latina. }\end{array}$ \\
\hline
\end{tabular}




\begin{tabular}{|c|c|}
\hline \multicolumn{2}{|c|}{ Saúde } \\
\hline $\begin{array}{l}\text { - Hoje, mais de } 60 \% \text { da população dos } \\
\text { países em desenvolvimento tem } \\
\text { acesso a serviços de saúde. } \\
\text { Mais de } 2 \text { bilhões de pessoas agora têm } \\
\text { acesso a água limpa e potável }\end{array}$ & $\begin{array}{l}\text { - } \quad 1,5 \text { bilhão de pessoas carecem de } \\
\text { cuidados básicos referentes à saúde. } \\
1,75 \text { bilhão de pessoas ainda não tem } \\
\text { acesso a uma fonte de água limpa e } \\
\text { potável }\end{array}$ \\
\hline \multicolumn{2}{|c|}{ Saúde infantil } \\
\hline $\begin{array}{l}\text { - As taxas de mortalidade infantil } \\
\text { (crianças com menos de } 5 \text { anos) } \\
\text { caiu pela metade entre } 1960 \text { e } \\
1988 \text {. } \\
\text { - A cobertura da imunização infantil } \\
\text { aumentou agudamente nos anos } \\
\text { 80, de } 30 \% \text { para } 70 \% \text {. Salvando } \\
\text { uma estimativa de } 1,5 \text { milhão de } \\
\text { vidas anualmente. }\end{array}$ & $\begin{array}{l}14 \text { milhões de crianças ainda } \\
\text { morrem todo ano antes de } \\
\text { completarem cinco anos de } \\
\text { idade. } \\
\text { - Aproximadamente } 3 \text { milhões de } \\
\text { crianças morrem de doenças } \\
\text { imunizáveis todos os anos. }\end{array}$ \\
\hline \multicolumn{2}{|c|}{ Alimentação e nutrição } \\
\hline $\begin{array}{l}\text { O suprimento calórico per capita } \\
\text { médio aumentou } 20 \% \text { entre } 1965 \\
\text { e } 1985 \text {. } \\
\text { - O suprimento calórico médio, que } \\
\text { representava } 90 \% \text { dos requisitos } \\
\text { em } 1965 \text {, passou a representar } \\
107 \% \text { dos requisitos totais em } \\
1985 .\end{array}$ & $\begin{array}{l}\text { - Um sexto das pessoas do Sul } \\
\text { ainda passa fome todos os dias. } \\
150 \text { milhões de crianças com } \\
\text { menos de cinco anos (uma em } \\
\text { cada três) sofrem de desnutrição } \\
\text { grave. }\end{array}$ \\
\hline \multicolumn{2}{|c|}{ Saneamento } \\
\hline $\begin{array}{l}\text { - } \quad \text { 1,3 bilhão de pessoas têm } \\
\text { acesso a saneamento adequado. }\end{array}$ & $\begin{array}{l}\text { - Aproximadamente } 3 \text { bilhões de } \\
\text { pessoas ainda vivem sem } \\
\text { saneamento adequado }\end{array}$ \\
\hline \multicolumn{2}{|c|}{ Mulheres } \\
\hline $\begin{array}{l}\text { - O número de matrículas } \\
\text { escolares de meninas aumentou } \\
\text { duas vezes mais rápido que o } \\
\text { número de matrículas de } \\
\text { meninos. }\end{array}$ & $\begin{array}{l}\text { - A taxa de alfabetização feminina } \\
\text { nos países em desenvolvimento } \\
\text { representa apenas dois terços da } \\
\text { taxa masculina. } \\
\text { - A taxa de mortalidade materna no } \\
\text { Sul é } 12 \text { vezes a do Norte. }\end{array}$ \\
\hline
\end{tabular}

(PNUD, 1990) 
Com relação ao meio ambiente os resultados também se tornaram alarmantes a partir da década de 1960. Considerando espaço como resultado de relações sociais num determinado tempo, a análise as transformações do mesmo por meio da evolução histórica da relação do ser humano com a natureza, e conseqüentemente as transformações nas formas de produção podem colaborar com a análise da questão ambiental engendrada no contexto histórico do fim do século XX.

Produzir significa tirar da natureza os elementos
indispensáveis à reprodução da vida. A produção, pois,
supõe uma intermediação entre o homem e a natureza
(...) produzir e produzir espaços são dois atos
indissociáveis (...) (SANTOS, 2004, p. 202-203).

Os primeiros grupos humanos nômades ao fixarem-se no espaço pelos meios de sobrevivência escolhidos, ou seja, pela forma de produção, transformaram o espaço e redefiniram a noção de tempo em função da necessidade de organização e disciplina que esse novo modo de produção exigia (SANTOS, 2004).

Desse estágio primitivo às grandes transformações do espaço e tempo redefinidas a partir do século $\mathrm{XVI}$ com as viagens renascentistas rumo ao espaço mundializado, e depois com as transformações radicais impressas definitivamente pela modernidade do modo de produção capitalista; faz-se necessária a interpretação menos literal da relação de produção de espaço a partir da demanda biológica do ser homem, e passa a ser mais apropriada a visão de espaço enquanto resultado da produção econômica internacional, que se impõem em diferentes níveis do local ao global.

O espaço local deixou de circunscrever-se em si mesmo para representar a concretização da complexidade global dos aspectos econômico, tecnológico, cultural, relacional.

SANTOS (op.cit.), chama esse processo de "universalização perversa, uma vez que não atinge todos os atores, não é utilizada 
igualmente por todos os agentes; e somente beneficia a uns poucos em detrimento do maior número" (p. 212), conforme os dados revelados pelos relatórios do PNUMA sobre IDH.

O meio ambiente passou a ser apenas uma mercadoria destinada a produção de outras mercadorias, cujo destino é o consumo por aqueles que estão inseridos no espaço global. O espaço local serve não mais à satisfação das necessidades de um grupo nele inserido, mas às necessidades definidas pela sociedade globalizada.

Como resultado desse sistema de produção deletério surgiram problemas ambientais que ultrapassaram o nível local e, assim como a universalização da produção, transformou-se em uma crise ambiental global sem precedentes, ameaçando não só os limites circunscritos no local, mas o planetário.

Entre os inúmeros acidentes que marcaram a área ambiental no século $X X$, destaca-se a fábrica da Union Carbide, em Bopal na Índia em 1984, que despejou 40 toneladas de isocianato de metila na atmosfera atingindo mais de 200 mil pessoas, das quais 4.500 morreram e muitas contraíram doenças respiratórias, problemas oculares e desordem mental (SMA, 2003).

A partir da definição de paradigma como a visão do mundo de uma determinada época, o "atual momento de transição paradigmática corresponde a uma mudança completa na visão do mundo que o novo paradigma deve representar" (SANTOS, 2004, p. 198).

Os desafios exigiram da experiência humana novos paradigmas na tentativa de entender e transformar as teorias no sentido de superar o maior deles que é a manutenção da vida dos seres vivos, com qualidade.

Segundo COIMBRA (1985) qualidade de vida é a somatória de fatores decorrentes da interação entre sociedade e ambiente, atingindo a vida no 
que concerne às suas necessidades biológicas, psíquicas e sociais inerentes e/ou adquiridas

Dessa forma a necessidade de repensar o mundo que se desfazia diante dos olhos menos míopes e se concretizava despedaçado em perdas significativas no âmbito social, econômico, ambiental e moral, acabou permeando o pensamento crítico e científico da época e concretizando-se nas produções e propostas para entender e minimizar as incertezas quanto ao futuro.

As situações que se descortinavam em diferentes espaços mundiais caminhando para a insustentabilidade do modo de vida da sociedade contemporânea, calcada na industrialização e no consumo, suscitaram manifestações por parte da opinião pública principalmente na Europa e nos Estados Unidos, a partir da década de 1960.

A comunidade científica internacional sensibilizada com os problemas ambientais de grande magnitude mobilizou-se para informar e alertar a opinião pública a respeito dos riscos vindouros em função do modelo de desenvolvimento vigente e os seus reflexos no meio ambiente. Ocorreu a intensificação no desenvolvimento de metodologias que pudessem responder às novas demandas dos problemas ambientais.

O lançamento do livro Primavera Silenciosa de Rachel Carson em 1962 nos Estados Unidos, sobre o impacto dos pesticidas e inseticidas sintéticos e a conseqüente perda da qualidade de vida, em decorrência da contaminação do meio ambiente abriu caminho para a divulgação da produção científica em linguagem acessível que popularizou o debate ambiental e suscitou discussões sobre consumo, poluição e degradação da saúde (CASCINO, 1999).

A formação do Clube de Roma, em 1968, por cientistas, economistas, intelectuais e empresários, teve como objetivo compreender como os diferentes aspectos econômicos, políticos, naturais e sociais relacionavam - 
se e repercutiam na crise ambiental, econômica e de valores da época. Após dois anos de estudos do Projeto sobre a Condição da Humanidade, a instituição lançou o relatório Limites do Crescimento (1970), que embora apresentasse problemas metodológicos e tivesse sofrido sérias críticas pelas propostas radicais como a redução do crescimento industrial, agrícola, da taxa de natalidade e transferência de recursos para os países pobres, representou um marco para o movimento ambientalista (PELICIONI, 2002).

Teve início um processo de busca por respostas e novos rumos para as questões sócio-ambientais. O presente trabalho procurou apresentar a questão tendo como referencial teórico e conceitual as orientações dos encontros e conferências internacionais sobre meio ambiente das últimas décadas, tendo como foco principal a Educação Ambiental enquanto possibilidade de tornar-se um instrumento de transformação da realidade global a partir de ações que se concretizam no nível local, especificamente no cotidiano escolar.

\subsection{EDUCAÇÃO AMBIENTAL E POLÍTICAS PÚBLICAS}

\subsubsection{Encontros internacionais}

O meio ambiente passou a fazer parte da pauta de organizações internacionais como a ONU, que por meio de suas agências promoveu diversos encontros internacionais a partir de 1968 na busca de novos caminhos que orientassem os governos e a sociedade civil para um rumo diferente do que as constatações indicavam. Os encontros e conferências destacados a seguir representam os marcos históricos e conceituais considerados nesse trabalho de pesquisa com relação à educação ambiental.

Em 1972 aconteceu em Estocolmo na Suécia, a 1aㅡ Conferência das Nações Unidas sobre o Meio Ambiente Humano que significou um marco 
importante pois pela primeira vez o tema meio ambiente estava na pauta da ONU e sendo discutido juntamente com as questões sociais e econômicas.

A reunião ficou marcada por desacordos entre os representantes dos países desenvolvidos e os dos países em desenvolvimento. A partir da comprovação e apresentação dos efeitos da degradação ambiental provocada pelo crescimento econômico exploratório, alguns grupos como o Clube de Roma, defenderam o "crescimento zero" como única forma de reverter o processo de degradação ambiental, a escassez de recursos energéticos e a decadência das cidades (BARBIERI, 2000).

Já países como o Brasil, China e Índia, que na década de 1970 estavam em períodos de grande desenvolvimento industrial, argumentaram em causa própria defendendo a necessidade e o direito ao desenvolvimento econômico como meio para a superação dos problemas sociais, ainda que houvesse um prejuízo ambiental, reproduzindo os ideais de desenvolvimento adotado pelos países desenvolvidos (BARBIERI, 2000).

Segundo BARBIERI (2000), a partir desse impasse surgiu a discussão sobre o modelo de desenvolvimento vigente e o neologismo que propunha um outro tipo de desenvolvimento o ecodesenvolvimento, cuja preocupação com o meio ambiente deveria ser prioridade. Após o Relatório Brundtland, em 1987, esse termo foi substituído por desenvolvimento sustentável.

Diante da gravidade dos problemas e das concepções divergentes dos representantes foi criado o Programa das Nações Unidas para o Meio Ambiente - PNUMA, com o objetivo de iniciar uma discussão internacional sobre a necessidade de mudanças diante dos problemas ambientais por meio de coordenação de políticas e implementação de um Plano de Ação Mundial relacionados à avaliação e gestão ambiental e às medidas necessárias para a execução destas como a educação e o treinamento de pessoal, informação e assistência financeira (MC CORMICK, 1992). 
Em 1974 foi criado o Programa Internacional de Educação Ambiental - PIEA, com a função de estruturar os parâmetros da educação voltada para a resolução dos problemas ambientais. A partir de então, a educação ambiental aparece com destaque em todos os encontros por ser considerada um instrumento importante na mediação de transformações sociais necessárias para um mundo mais justo.

Assim, em 1975 aconteceu o Encontro Internacional de Educação Ambiental em Belgrado na antiga lugoslávia patrocinado pela UNESCO, a partir do qual começou a se difundir a concepção de educação ambiental e os fundamentos para a estruturação da proposta pedagógica da educação ambiental dos órgãos responsáveis pela educação nos diferentes níveis local, nacional e regional.

Os objetivos da educação ambiental da Carta de Belgrado, são:

- conscientização: contribuir para que indivíduos e grupos adquiram consciência e sensibilidade em relação ao meio ambiente como um todo e quanto aos problemas relacionados com ele;

- conhecimento: propiciar uma compreensão básica sobre meio ambiente, principalmente quanto às influências do ser humano e de suas atividades;

- atitudes: propiciar a aquisição de valores e motivação para induzir uma participação ativa na proteção ao meio ambiente e na resolução dos problemas ambientais;

- habilidades: proporcionar condições para que os indivíduos e grupos sociais adquiram as habilidades necessárias para a participação ativa;

- capacidade de avaliação: estimular a avaliação das providências efetivamente tomadas em relação ao meio ambiente e aos programas de educação ambiental; 
- participação: contribuir para que os indivíduos e grupos desenvolvam o senso de responsabilidade e de urgência com respeito às questões ambientais.(UNESCO 1976 )

PELICIONI AF (2002) citando FENSHAN (1976) relata algumas discussões importantes que ocorreram no encontro de Belgrado, porém não apareceram na Carta. Entre elas, o questionamento por parte dos representantes latino-americanos da relação "entre os problemas ambientais e o tipo de desenvolvimento adotado por alguns países, atribuindo responsabilidades à economia internacional“(p.80), e propondo que a educação ambiental fundamentalmente fosse calcada numa nova ética que transcendesse as questões econômicas.

Em 1977 em Tbilisi, Geórgia, na 1a Conferência Intergovernamental sobre Educação Ambiental - Tbilisi foram definidas algumas diretrizes necessárias para que a educação ambiental fosse prioridade nas políticas públicas e passasse a ser implementada nos sistemas educacionais internacionalmente na década de 1990. As discussões e recomendações abrangeram temas como: modelo de curriculum, capacitação docente e discente, e educação universitária.

A abordagem interdisciplinar proposta teve destaque especial para a nova prática pedagógica relativa aos problemas ambientais, uma vez que estes foram considerados resultantes dos fatores econômicos, sociais, políticos, ecológicos (MEC, 1997).

PELICIONI AF (2002) acrescenta que na Conferência afirmou-se a necessidade da gestão ambiental ter como objetivo diminuir as desigualdades entre as nações e proporcionar relações internacionais pautadas na eqüidade segundo a "perspectiva de uma Nova Ordem Internacional", além da recomendação quanto à revisão do modelo de crescimento e desenvolvimento a partir da reavaliação do consumo diante da ótica dos impactos ambientais. 
Dessa forma, os objetivos da Educação Ambiental passaram a ser os seguintes:

- proporcionar compreensão clara em relação à existência e importância da interdependência econômica, política e ecológica nas áreas urbanas e rurais;

- proporcionar a todas as pessoas oportunidades para que adquiram os conhecimentos, os valores, as atitudes, as habilidades e o comprometimento necessários para proteger e melhorar o meio ambiente;

- propor novos padrões de comportamento aos indivíduos, grupos e toda a sociedade em relação ao meio ambiente

(UNESCO, 1978)

No Brasil, a Política Nacional do Meio Ambiente - Lei 6.938, de 1981, incorporou os objetivos da educação ambiental, definidos em Tbilisi, determinando seus princípios, objetivos e a necessidade de promovê-la em todos os níveis de ensino, formal e não formal.

Em 1987, o Congresso Internacional de Treinamento e Educação Ambiental realizado em Moscou e organizado pela PNUMA e UNESCO teve como objetivo discutir as dificuldades e o progresso da educação ambiental após Tbilisi. A avaliação dos especialistas foi que a manutenção do consumo e do modo de produção mundial, aliados aos problemas sócio-econômicos, dele decorrentes, manteve-se inalterado acarretando o agravamento dos problemas ambientais.

Desse encontro resultou um documento cujo objetivo foi orientar quanto à incorporação da educação ambiental aos sistemas educacionais intitulado "Estratégia Internacional para a Ação no campo de Treinamento e Educação Ambiental para aos Anos 90". (GOVERNO DO ESTADO DE SÃO PAULO, 1994). 
Em 1992 realizou-se no Rio de Janeiro a Conferência das Nações Unidas sobre Meio Ambiente e Desenvolvimento, o maior evento pautado nas questões ambientais da história, com dois fóruns paralelos de discussão: um oficial e outro popular.

Do lado oficial, a Conferência das Nações Unidas sobre Meio Ambiente e Desenvolvimento (CNUMAD), conhecida como o maior encontro de chefes de Estado já ocorrido na história, com mais de 170 representantes. Das discussões, resultaram cinco documentos com o compromisso de promover o desenvolvimento sustentável no século XXI, identificando ações combinadas de proteção ao meio ambiente com desenvolvimento.

O primeiro deles foi a Convenção sobre as Mudanças Climáticas com o compromisso de estabilizar e reduzir a emissão de gases poluentes, provenientes da queima de combustíveis fósseis (carvão mineral, gás natural e petróleo), principalmente pelos países desenvolvidos. A preocupação com a emissão de gases deve-se à possibilidade de aumento da temperatura média do planeta, e mudanças climáticas dela decorrentes.

Outro documento foi a Convenção sobre a Diversidade Biológica que definiu os princípios para a proteção da biodiversidade ameaçada nos diferentes ecossistemas do planeta por meio do estímulo à identificação e conservação de espécies em bases sustentáveis.

A Declaração dos Princípios sobre o Uso das Florestas embora não tenha força jurídica, obteve o primeiro consenso mundial sobre a questão e propunha que fosse dada ênfase à necessidade de conservação dos ecossistemas florestais por meio do manejo, recuperação e desenvolvimento sustentável das florestas. Nesse documento consta que os países desenvolvidos devem fornecer recursos financeiros para os países pobres a fim de viabilizar as ações nele propostas. 
A Declaração do Rio para ao Meio Ambiente e Desenvolvimento, carta que contém 27 princípios e obrigações dos Estados em relação ao meio ambiente e desenvolvimento, ratificou o direito soberano dos Estados em aproveitar seus recursos, porém orientando quanto a necessidade de que essas ações fossem norteadas para a sustentabilidade. Nessa declaração foi salientada a participação da mulher para que se pudesse garantir o desenvolvimento sustentável.

A Agenda 21 Global, documento assinado pelos países participantes, estabeleceu princípios e ações para a gestão ambiental de forma sustentável e teve por objetivo instrumentalizar a sociedade civil em diferentes níveis de organização no sentido de combinar desenvolvimento econômico e proteção ao meio ambiente, ao longo do século XXI.

A Conferência do Rio, em contraste com a Conferência de Estocolmo de 1972, orientou-se para o desenvolvimento, e a Agenda 21 não é uma agenda ambiental e sim uma agenda de desenvolvimento sustentável, onde, evidentemente, o meio ambiente é uma consideração de primeira ordem.

A Agenda 21 Global será tratada com destaque em um capítulo a seguir, uma vez que constitui-se em um importante marco conceitual para o desenvolvimento das Agendas Local e Escolar que surgiram a partir dela .

Simultaneamente à reunião oficial aconteceu o Fórum Global com a participação de representantes de 20 mil Organizações Não Governamentais - ONGs (MARTINS, 2002) de todas as partes do planeta militantes de causas diversas.

O Aterro do Flamengo no Rio de Janeiro tornou-se o palco de um fervilhar humano espetacular onde diferentes segmentos apresentaram suas causas, discutiram e propuseram alternativas.

Era possível encontrar grupos como o das senhoras devotas de Nossa Senhora de Guadalupe contra o aborto, grupos anti-nucleares, ONGs 
ambientalistas contra a caça às baleias, grupos contra a destruição de florestas, e outras inúmeras tendências; representantes de comunidades tradicionais brasileiras, aborígines, esquimós, sindicalistas, pacifistas; enfim, a diversidade da sociedade mundial mostrou as suas especificidades locais e pontuais pautadas pela busca comum da melhoria da qualidade de vida no planeta.

A síntese do Fórum da sociedade civil resultou no Tratado de Educação Ambiental para Sociedades Sustentáveis e Responsabilidade Global, cujo enfoque principal foi a educação ambiental como instrumento para a formação de sociedades socialmente mais justas e ecologicamente equilibradas, que conservam entre si relação de interdisciplinaridade e diversidade, responsabilidade individual e coletiva em nível local, nacional e internacional (PNEA, 2006).

Na Conferência Internacional sobre Meio Ambiente e Sociedade: Educação e Conscientização Pública para a Sustentabilidade, que aconteceu em Tessalônica - Grécia, em 1997, foi proposta a reorientação da educação como um dos pilares da sustentabilidade, aliada à economia, legislação e tecnologia, assinalando que a esta deve envolver e receber apoio de outros setores como o governamental e de instituições financeiras.

Frederico Mayor, então Diretor-Geral da UNESCO em 1997, pessimista quanto às metas definidas anteriormente declarou que “(...) transcorridos vinte anos da Conferência de Tbilisi e, cinco anos da ECO-92, quem ousaria negar que apenas o mínimo foi alcançado? (...)" (UNESCO, 1999, p.6).

Foram reiteradas todas as recomendações das Conferências anteriores que trataram sobre a educação ambiental, considerando que a educação e conscientização pública tiveram grande avanço a partir das mesmas, ainda que suas determinações não tenham sido exploradas totalmente. 
Especificamente em relação ao ensino formal apareceram dois itens nas recomendações, descritas a seguir :

Recomendação № 21. As escolas devem ser apoiadas e encorajadas a ajustarem seus currículos as necessidades de um futuro sustentável.

Recomendação № 24. Deve ser dada ênfase para o esforço e eventual reorientação dos programas de treinamento de professores e identificação e participação em práticas inovadoras. Deve ser dado apoio às pesquisas em metodologias de ensino interdisciplinar e na avaliação do impacto de programas educacionais relevantes (IBAMA, 2002, p. $116-117$ ).

Em 1997 em Nova lorque, houve um encontro para avaliar a os desdobramentos da Agenda 21 no mundo, conhecido como Rio + 5. O International Council for Local Environmental Initiatives (ICLEI), Organização não-governamental canadense, apresentou dados de pesquisa realizada no ano anterior ao encontro divulgando que até aquele momento 1812 cidades de 64 países realizaram atividades de estudos referentes à Agenda 21 locais e que 933 cidades em 43 países haviam iniciado um processo de planejamento para o desenvolvimento sustentável ( KOHLER, 2003).

Em 2002, no encontro da Cúpula Mundial sobre Desenvolvimento Sustentado realizado em Johanesburg, na África do Sul, a Rio + 10, houve a participação de um número expressivo de representantes governamentais de 193 países, 86 ONGs, 7200 delegados oficiais e milhares de militantes do mundo todo (MEC, 2006).

Dez anos após a Rio 92 e 40 anos após o lançamento de um dos livros considerado representativo do movimento ambiental "A Primavera Silenciosa" de Rachel Carson, em 1992, observou-se que os avanços na implementação de planos de ação e orientações quanto às medidas que deveriam ter sido implementadas nos níveis mundial, nacionais e locais, não foram significativos e não surtiram efeitos expressivos do ponto de vista da melhoria da qualidade de vida dos seres vivos. 
O documento resultante do encontro enfatizou a ratificação de todos os compromissos assumidos na Rio 92, assim como as orientações quanto as ações que devem ser implementadas para a conquista do desenvolvimento sustentável. Novamente os países signatários comprometeram-se em ampliar a cooperação internacional e promover o desenvolvimento sustentável baseado no tripé: crescimento econômico, desenvolvimento social e proteção ao meio ambiente.

No Plano de Implementação, a educação foi considerada um imperativo para concretizar as mudanças necessárias para 0 desenvolvimento sustentado em todos os temas que tratam a Agenda 21 Global (MEC, 2006). Nesse sentido indicam que organismos internacionais, como o Banco Mundial e bancos regionais de desenvolvimento deveriam prover recursos para a realização das ações necessárias.

Estipulou-se o prazo máximo até 2015 para que seja garantido o acesso universal ao ensino básico de todas as crianças do mundo, inclusive as que vivam em áreas rurais e em condição de pobreza, e que sejam eliminadas as disparidades de gênero.

Comprometem-se a prestar assistência financeira a programas educativos e de pesquisa em países em desenvolvimento relativos a meio ambiente e saúde pública, assim como o intercâmbio internacional entre centros de pesquisa.

$\mathrm{Na}$ visão de analistas que acompanharam a maior Conferência das Nações Unidas para o Desenvolvimento Sustentável, os 10 anos de Rio 92 ou de Agenda 21 representaram uma "década desperdiçada" (MARTINS, 2002). Segundo o autor, o Brasil esteve numa situação em que poderia tomar a dianteira do movimento em luta do desenvolvimento sustentável e perdeu a oportunidade de firmar-se internacionalmente por posturas mais rígidas e determinadas no trato das questões ambientais. Um dos fatores indicados como responsável pelo fracasso na implementação da Agenda 21 
foi a ampliação da distância entre os países do Norte e do Sul nesse período de economia globalizada.

Apesar dessa visão pessimista, o Prof. Dr. Marcos Reigota, em Conferência na Faculdade de Saúde Pública da Universidade de São Paulo, em outubro de 2002, salientou a riqueza do encontro do ponto de vista das discussões centradas na troca de experiências, com destaque para os representantes dos países africanos que viveram guerras civis, e uma " nova geração de brasileiros no debate ambientalista" buscando espaço para propor alternativas tendo o enfoque sócio-político em primeiro plano ( TOLEDO, 2002).

Com relação aos recursos e mecanismos de financiamento que os países ricos deveriam destinar aos países pobres, por intermédio da Assistência Oficial para o Desenvolvimento (ODA) como aporte para a implementação de programas de desenvolvimento, não chegou a 0,22\% do PNB desses países, valor bem abaixo dos $0,7 \%$ previstos. A exceção ficou por conta da Holanda que, em 1986, chegou a investir 1,01\% do seu PIB em programas de desenvolvimento nos países pobres (MARTINS, 2002).

Além da transferência de recursos, deveriam ser consideradas também as questões da transferência de tecnologia para a promoção da saúde, agricultura, gerenciamento sustentável, manutenção da biodiversidade, enfim, em todos os capítulos da agenda 21, a cooperação internacional financeira e tecnológica estão especificadas e 0 não cumprimento por parte dos organismos internacionais resultam em não efetivação do sonho da sustentabilidade.

\subsubsection{Educação Ambiental no ensino formal}

Desde a década de 1970, à medida em que foram acontecendo os encontros internacionais e a produção de conhecimento referente ao meio 
ambiente e educação ambiental, o Brasil também participou desse processo tendo construído o seu arcabouço institucional formado pelas políticas públicas nos níveis federal, estadual e municipal e pela instituição de políticas públicas voltadas para o meio ambiente (SMA, 2003).

A diferença entre política de governo e política pública é que a primeira traz propostas implementadas pelo governo que está exercendo o poder e que tem as prioridades de ação durante o seu mandato visando a melhoria da qualidade de vida da sociedade. Política pública , ao contrário é fruto de um processo participativo, com mobilização social dos formadores de opinião, de lideranças da sociedade, qual seja a dos representantes do poder legislativo, tanto nacional, quanto estadual ou municipal (KOHLER, 2003, p. 5).

O Estado de São Paulo iniciou o processo de construção de políticas públicas ambientais na década de 1970 e 1980 com a criação do Centro Tecnológico de Saneamento Básico - CETESB, que começou suas atividades em 1968 para atuar na área de engenharia sanitária, e a partir de 1975 passou a incorporar outras atribuições relacionadas à poluição do ar e do solo.

A Lei 6.938, de 31 de agosto de 1981, instituiu a Política Nacional de Meio Ambiente criando o Sistema Nacional de Meio Ambiente (SISNAMA) estabelecendo os fins, os objetivos e instrumentos para tratar de assuntos relacionados ao meio ambiente, além da obrigatoriedade de criação de órgãos ambientais nos níveis Estadual e Municipal. Constituiu-se no primeiro aparato jurídico a definir a educação ambiental como instrumento necessário para a formação da cidadania no ensino formal e não formal, visando a defesa do meio ambiente (SEMA, 2003).

Em 1984, foi formado o Conselho Estadual do Meio Ambiente (CONSEMA) em São Paulo que elaborou a Política Estadual do Meio Ambiente e dos Recursos Naturais e definiu as diretrizes, prioridades e estratégias da gestão ambiental no Estado, tendo destaque especial o planejamento e a educação ambiental. 
Considerava-se nesta época a educação ambiental como "um dos caminhos mais seguros para formar uma mentalidade conservacionista e comunitariamente abrangente para a defesa do meio ambiente e dos recursos naturais, e para a gestão desses recursos, tendo em vista a harmonização dos objetivos econômicos e sociais" (GOVERNO DO ESTADO DE SÃO PAULO, 1984, p. 6).

Nesse momento, definiram-se também as diretrizes que a educação ambiental deveria seguir no Estado de São Paulo, isto é:

- Incentivar a introdução de temas e atividades de educação ambiental, nos programas dos cursos da rede oficial e particular de ensino em todos os graus;

- Incentivar o envolvimento da comunidade na conservação do meio ambiente, através dos meios de comunicação de massa, prioritariamente o rádio e a televisão educativos;

- Incentivar o uso das áreas de parques, reservas, estações ecológicas, bem como de instituições de ensino e pesquisa de propriedade do estado, para fins de educação ambiental;

- Organizar programas de acesso da população a áreas onde existam monumentos naturais e arqueológicos, visando a implementação de atividades de educação ambiental;

- Incentivar a instalação de áreas, espaços e laboratórios comunitários destinados a programas de educação ambiental.

(SMA, 2003 p. 12)

A CETESB era responsável pela educação ambiental no Estado, tendo entre outras atribuições o planejamento, produção de material e realização de cursos de educação ambiental para os professores da rede estadual.

As concepções sobre a educação ambiental nesse momento refletem uma tendência muito voltada para as relações homem-natureza seguindo 
um modelo de pensamento "ecologista" para o qual "a problemática ecológica é tomada como sinônimo de problemática ambiental e meio ambiente, como noção normativa da práxis ecologista" (REIGOTA, 1999ª , p.19).

TOLEDO (2002) estudando o trabalho de educação ambiental em Unidades de Conservação do Estado verificou que o contato direto com a natureza "facilita" a compreensão das relações que nela ocorrem, mas que a educação ambiental não deve restringir-se à noção de conservação dos recursos naturais, uma vez que " (...) é insuficiente para uma educação que se pretenda crítica e transformadora da realidade" (p.31).

Em 1986, atendendo à orientação do SISNAMA é constituído o Sistema Estadual do Meio Ambiente formado pela Secretaria Estadual do Meio Ambiente (SEMA), Fundação Florestal e CETESB (Companhia de Tecnologia de Saneamento Ambiental, renomeada em 1976).

A Constituição Brasileira promulgada em 1988, dedicou o Capítulo VI ao meio ambiente e no art.225 determinou o que cabe ao "poder público promover a educação Ambiental em todos os níveis de ensino e a conscientização pública para a preservação do meio ambiente “.

No mesmo ano, a Secretaria de Educação do Estado de São Paulo, por meio da Coordenadoria de Estudos e Normas Pedagógicas (CENP), fez uma grande reformulação curricular para o Estado, substituindo a antiga proposta do Guia Curricular chamado "Verdão". A justificativa para a mudança baseou-se nos " altos índices de evasão e repetência, no baixo rendimento da aprendizagem e o desinteresse crescente pelos diferentes componentes curriculares manifestados pelos alunos da escola de 1ำ grau " ( SE/CENP 1988a p. 13).

Foram lançadas as Propostas Curriculares para o Ensino de 1ำ grau ( hoje ensino fundamental I - $1^{\mathrm{a}}$ a $4^{\mathrm{a}}$ séries e fundamental II - $5^{\mathrm{a}}$ a $8^{\mathrm{a}}$ séries) elaboradas coletivamente pelos técnicos da Secretaria de Educação, com a 
participação de professores de todo o Estado, de docentes de diferentes universidades, de sindicatos e entidades de classe. Com isso pretendeu-se romper a divisão de papéis entre os produtores do saber (produção acadêmica) e os transmissores do saber (professores). Da mesma forma, o aluno também passou a ser considerado não mais como um receptáculo de informações mas como um ser crítico inserido numa sociedade em transformação com capacidade de construir o seu saber (SE/CENP 1988b). Em 1994, essas propostas foram revisadas.

A principal preocupação dessa proposta foi " subsidiar a ação docente estabelecendo os objetivos e os conteúdos mínimos" (SE/CENP, 1988, p. 3a) a serem garantidos em todo o Estado de São Paulo; uma organização curricular organizada de forma multidisciplinar, porém com vistas a integração metodológica interdisciplinar, onde o tema meio ambiente era destaque (SE/CENP, 1988b, p. 17).

Após várias mudanças estruturais e administrativas, em 1989 a educação ambiental passou a fazer parte das atribuições da Coordenadoria do Meio Ambiente (CEAM) na Secretaria do Meio Ambiente - SEMA que mantinha em áreas distintas a educação ambiental para o ensino formal e não formal. Nesse período foi produzido material didático composto por publicações e vídeos, além de terem sido ministrados diversos cursos para a formação de professores com o objetivo de atualizar conteúdos relacionados às questões ambientais (dados obtidos em entrevista realizada com a Coordenadora da CENP).

Entre essas publicações destacam-se: Série Argumentos, Práticas Pedagógicas e uma coleção de nove vídeos produzidos para cada disciplina. O tema meio ambiente foi tratado com muito destaque tendo em vista suprir as carências metodológicas para o trabalho interdisciplinar. (dados obtidos em entrevista realizada com a Coordenadora da CENP).

A Secretaria do Meio Ambiente divulgou em 1993, o documento Diretrizes para a Política Ambiental do Estado de São Paulo. Estas diretrizes 
orientaram um conjunto de programas, entre elas o programa Instrumentos de Gestão Ambiental no qual estava incluída a educação ambiental.

Em 1995, com o início de uma nova gestão de governo, foi lançado o documento Implantação da Agenda 21 no Estado de São Paulo, e um Programa de Estadual de Educação Ambiental tendo como base os seguintes eixos: ensino e meio ambiente, cidadania e participação popular, capacitação profissional e desenvolvimento sustentável, comunicação e informação.

Para o Programa de Estadual de Educação Ambiental, considerado prioritário para a implantação da Agenda 21 em São Paulo foram traçadas algumas diretrizes importantes:

- Desenvolvimento de ações continuadas e permanentes que ultrapassem as conjunturas políticas e as gestões de governo;

- A inclusão de novos atores sociais na gestão pública do meio ambiente, como ONGs, a sociedade civil, as universidades, o empresariado, os trabalhadores, as comunidades tradicionais e os municípios;

- A articulação de ações existentes nos diversos âmbitos do governo, conferindo-lhes um sentido interativo e pedagógico;

- A valorização e a participação dos cidadãos na solução dos problemas ambientais.

Para atender a essas diretrizes foi assinada a Resolução n /1995 que estabeleceu uma parceria entre a Secretaria do Meio Ambiente e a Secretaria de Educação com o objetivo de desenvolver, pela primeira vez, uma política integrada de educação ambiental voltada para a capacitação dos profissionais da educação (professores, coordenadores pedagógicos e Assistentes Técnicos Pedagógicos-ATP). 
Os cursos realizados procuraram estimular a utilização de práticas pedagógicas interdisciplinares, desenvolvimento de tecnologias de projetos e a produção didático-pedagógico para o Ensino Fundamental .

No sentido de desenvolver ações continuadas a Secretaria de Educação iniciou um processo de descentralização dando autonomia às Diretorias de Ensino Regionais para a contratação de cursos, especialistas e aquisição de material.

Foram firmados acordos com o setor privado para a realização de vários projetos. Entre os patrocinadores destacaram-se a FIAT, PROCEL (Papel e Celulose), Editora Horizonte Geográfico e TETRAPAC (embalagens).

Os temas dos projetos eram relacionados a questões ambientais de interesse relevante do ponto de vista de demandas públicas, no entendimento dos órgãos responsáveis, como por exemplo: recursos hídricos, resíduos sólidos, poluição do ar, energia, resíduos sólidos.

No âmbito Federal em 1998 o Ministério da Educação e do Desporto lançou os Parâmetros Curriculares Nacionais - PCNs para servir como referencial curricular para o território nacional nos módulos: Educação Infantil, Ensino Fundamental I ( $1^{\text {a }}$ a $4^{\mathrm{a}}$ série), Ensino Fundamental II ( $5^{\text {a }}$ a $8^{*}$ vu série) e Ensino Médio. Seu objetivo foi promover uma transformação no sistema educacional brasileiro "procurando de um lado, respeitar diversidades regionais, culturais, políticas existentes no país e, de outro, considerar a necessidade de construir referenciais nacionais comuns ao processo educativo em todas as regiões brasileiras. Com isso pretende-se criar condições, nas escolas que permitam aos nossos jovens ter acesso ao conjunto de conhecimentos socialmente elaborados e reconhecidos como necessários ao exercício da cidadania "( MEC/SEF, 1998, p. 5).

Os PCNs foram muito criticados por especialistas brasileiros por considerarem que os mesmos não estão de acordo com a produção teórica 
brasileira e por veicularem o discurso político neoliberal do grupo que, historicamente, detém o poder e pouco tem feito para alterar os problemas sociais, e as injustiças no país (REIGOTA, 2000).

Uma questão colocada pelos pesquisadores foi sobre a definição de parâmetros nacionais homogêneos para um país que possui dimensões continentais e realidades muito antagônicas. Ainda, é preciso considerar que o conhecimento não é algo acabado, mas sim o resultado mutante das experiências permanentes das relações sociais, o que o faz com que ele esteja em constante construção (ALVES e GARCIA, 2004).

Em São Paulo, assim como em outros Estados, o ensino formal vinha construindo uma história conceitual e de práticas pedagógicas, que deveria ter sido considerado, principalmente pelas experiências acumuladas, e pela característica participativa com que o processo foi conduzido.

Juntamente com a publicação dos PCNs foram elencados alguns temas que, no entender do Ministério, “(...) norteiam a construção da cidadania e a democracia (...) permeiam todos os campos do conhecimento além de levarem em conta fatores como: urgência social, a abrangência nacional, a possibilidade de ensino e aprendizagem no ensino fundamental e o favorecimento da compreensão da realidade e a participação social (...) e devem ser tratados de forma transversal ao conteúdo curricular" (MEC/SEF, 1998, p. 25). São eles: meio ambiente, ética, a pluralidade cultural brasileira, orientação sexual, saúde e trabalho.

REIGOTA (2000) considera que os temas transversais, da forma como foram apresentados fogem da concepção política-pedagógica " radical" que a proposta da transversalidade enseja.

O autor buscou o significado da transversalidade nas propostas teóricas e políticas do "pensamento de 68", destacando Felix Gattai, e no pensamento pedagógico de Paulo Freire, para os quais o conhecimento não 
deve ser hierarquizado nem pode haver separação entre a arte, a ciência e o cotidiano. Partindo dessa concepção considera que:

A transversalidade pensada desse modo, não exclui as mais diversas fontes de conhecimento que permitem a compreensão do outro, e que contribui efetivamente para uma intervenção constante, irredutível no tempo e no espaço em que se vive. Dessa forma a transversalidade está intimamente ligada ao cotidiano e ao conhecimento, sem barreiras e limites, sejam elas visíveis ou não (p. 23).

As questões ambientais e a educação ambiental estão presentes não só na formalidade da legislação instituída no ensino formal paulista, desde a década de 1980, mas principalmente no cotidiano da escola pública. Não há como deixar de abordar as transformações do espaço resultantes do processo histórico no cotidiano escolar vivendo num ambiente efervescente social, econômica e culturalmente. Ainda que se faça uma análise do material produzido nas escolas, e este apresente concepções com diferentes matizes do conhecimento, há que se considerar o movimento e as transformações como constituintes do processo de criação cultural dessa sociedade.

\subsubsection{Educação e a sustentabilidade}

Passadas três décadas de discussões sobre as questões ambientais com grande popularização e interesse pelo tema meio ambiente, a educação ambiental tem sido apontada como um instrumento fundamental para abordar tais questões.

O termo desenvolvimento pressupõe a idéia de processo de transformação, de etapas. Da mesma forma que é extremamente tendenciosa a utilização do termo subdesenvolvimento no sentido de levar a acreditar que os países assim definidos um dia poderão se tornar desenvolvidos, sem levar em consideração o processo histórico que definiu 
a sua condição atual; o termo desenvolvimento sustentável também precisa ser entendido com um certo cuidado.

O conceito de desenvolvimento partiu da ótica hegemônica da sociedade industrial, consumista, antropocêntrica e imediatista, generalizando-se e universalizando-se em todos os espaços. SANTOS (2004) chama esta situação de " universalização perversa, uma vez que não atinge a todos os atores, não é utilizada igualmente por todos os agentes; e somente beneficia a uns poucos, em detrimento do maior número" ( p. 212).

As questões ambientais vão muito além de problemas ambientais e do nível econômico das atividades humanas. Muitos autores passaram a transgredir o discurso dominante e “ (...) pensar no problema global sob a perspectiva de sociedade ou sociedades sustentáveis e não desenvolvimento sustentável. Isso significa que cada sociedade deve se estruturar em termos de sustentabilidades próprias, segundo seus valores e parâmetros específicos." ( PELICIONI AF, 2002, p. 94).

PELICIONI MCF (2000) considera a " educação enquanto prática político pedagógica determinada histórica e socialmente, pretende possibilitar o desenvolvimento de estratégias de ação, que venham contribuir para a construção do processo de cidadania e para a melhoria da qualidade de vida da população" (p.10).

A educação voltada para as questões ambientais requer um posicionamento crítico e análise de diversos fatores determinantes, incluindo as relações de poder subjacentes, para que possa conduzir a um processo de transformação da realidade.

Para REIGOTA (2000) "o compromisso político de toda pessoa interessada em praticar educação ambiental deve estar relacionado com a possibilidade (utópica) de construção de uma sociedade sustentável baseada na justiça, dignidade, solidariedade, civilidade, ética e cidadania" ( p. 34), e posiciona a educação ambiental como instrumento de abordagem 
política da realidade na condução de uma sociedade sustentável, a partir de fundamentação .

Da mesma forma, PHILIPPI JR e col. (2002) acreditam que a verdadeira sustentabilidade requer uma sociedade humana sustentável, assim como uma educação ambiental sustentável voltada para a formação da "consciência planetária, pelo aguçado sentido do desenvolvimento humano, pela promoção da vida e por critérios éticos universais, lúcidos e firmes" (p. 329).

A educação ambiental deve, portanto, capacitar os indivíduos ao pleno exercício da cidadania, permitindo a formação de uma base conceitual suficientemente diversificada técnica e culturalmente, de modo a permitir que sejam superados os obstáculos à utilização sustentável do meio [...] Nos níveis formais e informais tem procurado desempenhar esse difícil papel resgatando valores como o respeito à vida e à natureza, entre outros, de forma a tornar a sociedade mais justa e feliz (PELICIONI 2000 p. 19).

O grande desafio que se coloca para a educação formal é a sua incorporação, pautada nos valores da sustentabilidade, no seu cotidiano. Muito se tem realizado no sentido de formação de consciência e capacitação técnica, porém, nem sempre as diretrizes políticas vigentes caminham no sentido de construir uma sociedade mais justa e igualitária.

\subsection{AGENDA 21 COMO INSTRUMENTO DE GESTÃO}

A Agenda 21 Global é um programa de ações, um documento de 4 seções e 40 capítulos que constitui a mais ousada e abrangente tentativa já realizada de promover, em escala planetária, um novo padrão de desenvolvimento, conciliando métodos de proteção ambiental, justiça social e eficiência econômica. 
O nome Agenda vem do seu sentido de intenções, desígnio, desejo de mudanças para um modelo de civilização em que predomine o equilíbrio ambiental e a justiça social entre as nações.

Cada capítulo da Agenda é formado de uma introdução ao assunto ou problema ambiental em questão descrita como base para a ação, objetivos, atividades e meios de implementação nos níveis global, nacional e local, incluindo estimativas de recursos financeiros necessários para a execução das propostas sugeridas.

Trata-se de um documento consensual para o qual contribuíram governos e instituições da sociedade civil de diferentes países num processo preparatório que durou dois anos e culminou com a realização da Conferência das Nações Unidas sobre Meio Ambiente e Desenvolvimento (CNUMAD), em 1992, no Rio de Janeiro, também conhecida por ECO-92.

O documento atribui o êxito das propostas aos Governos nacionais que devem comprometer-se em executá-las, e à cooperação internacional no sentido de apoiar e complementar esforços nacionais. Nesse sentido também considera o papel das organizações não governamentais e de outros grupos que possam contribuir e participar do esforço para a conquista do desenvolvimento sustentável (CNUMAD, 1997).

A Seção I refere-se às dimensões sociais e econômicas já indicando a impossibilidade de tratar das questões ambientais independentemente das questões sociais e econômicas. A seção II trata da conservação e gerenciamento dos recursos para desenvolvimento, considerando os recursos naturais e sua gestão. A seção III é voltada para a formação de recursos humanos e a para o fortalecimento do papel destes para a participação no desenvolvimento sustentável, dando ênfase especial às mulheres, infância, adolescência e populações tradicionais. A seção IV refere-se aos meios de implementação da Agenda 21 Global orientando quanto aos recursos e mecanismos de financiamento, transferência de 
tecnologia, cooperação, fortalecimento institucional, promoção do ensino, da conscientização e do treinamento.

A Agenda 21 Global propõe um processo de planejamento participativo que analisa a situação atual de um país, estado, município e/ou região, e planeja o futuro de forma sustentável. Esse processo de planejamento deve envolver todos os atores sociais na discussão dos principais problemas e na formação de parcerias e compromissos para a sua solução a curto, médio e longo prazo.

Nesse sentido BORN (1998/1999) considera "a Agenda 21 um processo voltado para a identificação, implementação, monitoramento e ajuste, de um programa de ações e transformações em diversos campos da sociedade. Trata-se de um processo que resgata a raiz básica ao planejamento, ao apontar para cenários desejados e possíveis, cuja concretização passa pela pactuação de princípios, ações e meios entre os diversos atores sociais, no sentido de aproximar o desenvolvimento de uma dada localidade, região ou país, aos pressupostos e princípios da sustentabilidade do desenvolvimento humano. Portanto, deve ser processo público e participativo, em que haja o envolvimento dos agentes sociais" (p.11)

A metodologia proposta para a utilização da Agenda 21 pressupõe uma abordagem integrada e sistêmica das dimensões econômica, social, ambiental e político-institucional. Deve surtir efeitos gerando produtos concretos, exeqüíveis e mensuráveis derivados de compromissos pactuados entre todos os atores, fator que garante a sustentabilidade dos resultados.

Os Governos têm a prerrogativa e a responsabilidade de deslanchar e facilitar o processo de implementação em todas as escalas. Além dos Governos, a convocação da Agenda visa mobilizar todos os segmentos da sociedade, chamando-os de "atores relevantes" e "parceiros do desenvolvimento sustentável" (MMA 1998). 
Apesar do grande número de países signatários da Agenda 21 Global, esta configura-se como uma soft-law, o que significa que não tem força de lei e portanto, não cria vínculos legais para os países que a assinaram. Dos acordos tratados na Rio-92 apenas a Convenção das Mudanças Climáticas e a Convenção sobre a Biodiversidade Biológica são do tipo hard-law, ou seja, que implicam em obrigatoriedade jurídica para os signatários (KOHLER, 2003).

\subsubsection{Agenda 21 Brasileira}

A construção de Agendas 21 nacionais, regionais ou locais deve ter como condições prioritárias o processo participativo envolvendo os diversos atores sociais, como representantes da sociedade civil, governo e setor produtivo, e o aspecto propositivo de maneira que não se atenha apenas ao diagnóstico situacional de uma determinada área, mas que emita propostas, recomendações e projetos a serem implementados pela sociedade como um todo (KOHLER, 2003).

Os dados de 2002 do ICLEl constataram que, atendendo às orientações da Agenda 21 Global 19 países estavam desenvolvendo Agendas 21 Nacionais, sendo eles agrupados por região: África: África do Sul; Ásia- Pacífico: China, Japão, Coréia do Sul, Mongólia, Sri Lanka, Austrália; Europa: Dinamarca, Finlândia, Irlanda, Islândia, Itália, Noruega, Reino Unido, Suécia; Oriente Médio: Turquia; América Latina: Brasil, Equador e Peru. Desses países o Brasil não havia finalizado a sua agenda até o momento da pesquisa, embora a autora tenha incluído-o na lista. Quanto às Agendas Locais o mesmo instituto confirmou que 6000 governos locais estavam incorporando a Agenda 21 Local em suas gestões (KOHLER 2003).

Com relação aos países detectados pela pesquisa, o resultado demonstrou que a maioria deles pertence ao grupo dos países 
desenvolvidos, o que coincide com as observações de PHILIPPI JR (2001) quanto à importância da tradição democrática para a implementação da Agenda 21, uma vez que o processo participativo dos cidadãos nas decisões acontece de forma mais fácil, tanto pelo nível de informação da população como pela prática cidadã. A situação é oposta nos países subdesenvolvidos, onde a tradição autoritária e com poder centralizador dificulta a implementação de propostas participativas.

Atendendo às orientações da Agenda 21 Global o Brasil iniciou o processo de construção de sua Agenda nacional em 1997 com a criação do Comissão de Políticas de Desenvolvimento Sustentável (CPDS) que entre outros objetivos deveria redefinir o modelo de desenvolvimento do país, tendo como base o conceito de sustentabilidade (CPDS, 2002).

Segundo BORN (1998-1999) a Agenda 21 Brasileira foi iniciada efetivamente só após a Rio + 5 (1997) sob a coordenação da CPDS e com a participação de Ministérios, Organizações não-governamentais, Fundação Getúlio Vargas e Universidade Federal de Minas Gerais. Foi definida a metodologia, os temas para a discussão e aberta concorrência pública para a formação de consórcios que deveriam elaborar os documentos e consulta pública nacional, uma vez que a Agenda deve ser participativa.

A demora em iniciar o processo pode ser decorrente da situação já citada anteriormente, de nos encontrarmos na situação dos países sem tradição em processos de gestão participativa, o que acarreta em pouco interesse por parte do governo em implementá-los.

Foram escolhidos seis temas para a discussão nacional e elaboração de estratégias e ações: Cidades Sustentáveis, Agricultura Sustentável, Infra-estrutura e Integração Regional, Redução das Desigualdades Regionais, Ciência e tecnologia e desenvolvimento Sustentável, Gestão de Recursos Naturais (MMA, 1998). 
Em maio de 2002 a CPDS finalizou o processo com a análise dos resultados obtidos no processo de discussão nacional em seminários com reuniões setoriais onde participaram: executivo, legislativo, academia e sociedade civil organizada.

Em julho de 2002 foi finalizada a elaboração da Agenda 21 Brasileira que conta com dois documentos: "Agenda 21 Brasileira: Resultado da Consulta Nacional" e Agenda 21 Brasileira: Ações Prioritárias" onde estão as propostas para a implementação para o desenvolvimento sustentável no país.

Analisando o processo de construção da Agenda 21 Brasileira, KOHLER (2003) esclarece que embora tenha havido o planejamento do processo participativo por meio de fóruns Estaduais para a discussão dos temas da Agenda " (...) esses eventos foram muito pouco participativos pelo fato de que a divulgação foi muito pequena. As instituições de ensino, como universidades, por exemplo, quase não participaram" ( p. 37).

\subsubsection{Agenda 21 Local}

O capítulo 28 da Agenda 21 Global Iniciativas das Autoridades Locais em Apoio à Agenda 21 trata especificamente sobre o papel das iniciativas locais como base para a estruturação das Agendas regionais e nacionais, uma vez que é no nível local que se concretizam as ações, onde se exercita a cidadania e onde são, imediatamente, detectados os problemas ambientais.

Dessa forma as bases para a ação nele enunciadas são :

28.1. Como muitos dos problemas e soluções tratados na Agenda 21 têm suas raízes nas atividades locais, a participação e cooperação das autoridades locais será um fator determinante na realização de seus objetivos. As autoridades locais 
constroem, operam e mantêm a infra-estrutura econômica, social e ambiental, supervisionam os processos de planejamento, estabelecem as políticas e regulamentações ambientais nacionais e sub-nacionais. Como nível de governo mais próximo do povo, desempenham um papel essencial na educação, mobilização e resposta ao público, em favor de um desenvolvimento sustentável (CNUMAD, 1997, p. 473).

A cidade de São Paulo foi a primeira a iniciar a construção da sua Agenda Local em 1995 por um grupo intersecretarial e finalizou o processo em 1996 produzindo vários materiais informativos que serviram de apoio metodológico para outras experiências no Brasil. A descontinuidade político-administrativa interrompeu sua implantação e a continuidade do processo (KOHLER, 2003).

KOHLER (2003) ao estudar e analisar o processo de construção de Agenda 21 Local em quatro cidades brasileiras - São Paulo, Rio de Janeiro, Florianópolis e Santos, indicou aspectos "facilitadores" e dificuldades para o desenvolvimento do processo.

Os aspectos facilitadores: apoio do poder executivo municipal, existência de um grupo de coordenação bem integrado, autonomia desse grupo, envolvimento e a articulação do processo junto a comunidade local.

Algumas dificuldades: descontinuidade administrativa, fator financeiro, falta de tradição participativa, pouca divulgação na mídia, falta de apoio dos Governos Federal e Estadual.

O Ministério do Meio Ambiente por meio do Departamento de Articulação Institucional tem realizado pesquisa junto aos Estados e municípios para acompanhar o processo de desenvolvimento das Agendas 21 nessas instâncias. Segundo os dados do relatório de 2002 foram identificadas 204 experiências de Agendas 21 Locais no Brasil, das quais apenas 4 estavam concluídas e as demais em processo de elaboração. 


\subsection{EDUCAÇÃO E AGENDA 21}

\subsubsection{Ensino formal e Agenda 21 Global}

O capítulo 36 trata especificamente sobre o papel da educação na construção do desenvolvimento sustentável, ainda que em todos os capítulos a educação também se apresente com um papel fundamental.

O referencial teórico deste capítulo baseou-se nos preceitos da Conferência de Tbilisi sobre Educação Ambiental e apresenta três áreas de programas:

a) Reorientação do ensino no sentido do desenvolvimento sustentável;

O ensino, inclusive o ensino formal, a conscientização pública e o treinamento devem ser reconhecidos como um processo pelo qual os seres humanos $e$ as sociedades podem desenvolver plenamente suas potencialidades. $O$ ensino tem fundamental importância na promoção do desenvolvimento sustentável e para aumentar a capacidade do povo para abordar questões de meio ambiente e desenvolvimento, ainda que o ensino deve ser incorporado como parte essencial do aprendizado (...) Para ser eficaz, o ensino sobre o meio ambiente e desenvolvimento deve abordar a dinâmica do desenvolvimento do meio físico/biológico e do sócio econômico e do desenvolvimento humano (que pode incluir o espiritual) deve integrar-se em todas as disciplinas e empregar métodos formais e meios efetivos de comunicação (CNUMAD, 1997, p. 533-534).

Entre os objetivos definidos para atender à essa primeira área do programa, destacam-se: garantir acesso universal ao ensino reduzindo as taxas de analfabetismo e a promoção da educação ambiental.

Para que sejam alcançados esses objetivos no ensino formal destacam-se algumas atividades:

Os governos devem atualizar ou preparar estratégias 
destinadas a integrar meio ambiente e desenvolvimento como tema interdisciplinar ao ensino de todos os níveis nos próximo três anos(...) Deve-se respeitar devidamente as necessidades definidas pela comunidade $e$ os diversos sistemas de conhecimentos, inclusive a ciência e a sensibilidade cultural e social;

As autoridades pertinentes devem assegurar que todas as escolas recebam ajuda para a elaboração de planos de trabalho sobre as atividades ambientais, com a participação dos estudantes e pessoal. As escolas devem estimular a participação dos escolares nos estudos locais e regionais sobre saúde ambiental, inclusive água potável, saneamento, alimentação e os ecossistemas e nas atividades pertinentes, vinculando esse tipo de estudo com os serviços e pesquisas realizados em parques nacionais, reservas de fauna e flora, locais de herança ecológica etc (...)

(CNUMAD, 1997, p. 535-537)

O documento também orienta que o PNUMA em colaboração com os órgãos pertinentes do sistema das Nações Unidas, os Governos, as organizações não governamentais e outras entidades devem estabelecer um programa em um prazo de dois anos, para integrar as decisões da Conferência à estrutura existente das Nações Unidas, adaptando para as necessidades de educadores de diferentes níveis e circunstâncias.

Com relação ao acesso à educação, as orientações da UNESCO, PNUMA e CNUMAD começaram a ser incorporadas oficialmente ao sistema educacional brasileiro, em nível nacional, a partir da Lei de Diretrizes e Bases - Lei no 9.394, de 20 de dezembro de 1996, que estabelece a obrigatoriedade e gratuidade do ensino fundamental a todos os cidadãos brasileiros, além da progressiva extensão para o ensino médio. Esta última garantia foi alterada pela Emenda Constitucional n 14/96 para "progressiva universalização do ensino médio", o que significa que é um direito e não uma obrigatoriedade.

b) Aumento da consciência pública:

(...) Os países em desenvolvimento, em particular, 
carecem da tecnologia e dos especialistas competentes. É necessário sensibilizar o público sobre os problemas de meio ambiente e desenvolvimento, fazê-lo participar de suas soluções, fomentar o senso de responsabilidade pessoal em relação ao meio ambiente e uma maior motivação e dedicação em relação ao desenvolvimento sustentável (CNUMAD, 1997, p. 540).

É necessário destacar que a sensibilização e a conscientização não implicam necessariamente em mudanças conforme esclarece PELICIONI MCF e PHILIPPI JR (2005, p. 5-6) " a consciência ecológica não garante uma ação transformadora. Para que a educação ambiental se efetive, é preciso que conhecimentos e habilidades sejam incorporados, e que principalmente atitudes sejam formadas a partir de valores éticos e de justiça social, pois são essas atitudes que predispõem à ação".

c) Promoção do treinamento:

O treinamento é um dos instrumentos mais importantes para desenvolver recursos humanos e facilitar a transição para um mundo mais sustentável. Ele deve ser dirigido a profissões determinadas e visar preencher lacunas no conhecimento e nas habilidades que ajudarão os indivíduos a achar emprego e a participar de atividades de meio ambiente e desenvolvimento(...) (CNUMAD, 1997, p. 543).

Existe uma distância muito grande entre treinamento e educação. $\mathrm{O}$ treinamento é necessário porém, ele por si só prepara para a realização de ações repetitivas, automatizadas. Ao passo que a educação pressupõe uma ação reflexiva, crítica, criativa, que possibilite a tomada de posição diante de diferentes situações. Portanto, a construção da sustentabilidade é preciso garantir educação para a sociedade. 


\subsubsection{Agenda 21 Escolar}

A Agenda 21 Escolar pode ser um dos caminhos que leve a proposta de sustentabilidade à escola.

A Secretaria da Educação do Estado de São Paulo (SEE-SP) por meio da Coordenadoria de Normas Pedagógicas (CENP) iniciou em novembro de 2004 um projeto de implantação da Agenda Ambiental nas escolas.

O tema norteador foi a água com a justificativa de ser um dos recursos naturais, cuja preservação e manutenção ganharam destaque nos últimos anos "em decorrência da comprovada escassez e comprometimento dessas reservas que, antes, se imaginava serem inesgotáveis (...)" (SEE/CENP, 2004, p.3).

Em todo o percurso de propostas de trabalho com educação ambiental da Secretaria de Educação a água tem sido um tema recorrente, inclusive em diversas parcerias com a SABESP, TV Cultura, Secretaria do Meio Ambiente, ONGs e outras instituições.

As políticas públicas referentes à gestão dos recursos hídricos têm recebido atenção especial por parte dos governos em virtude da situação crítica constituída por fatores complexos e convergentes. O Estado de São Paulo não foge à regra, especialmente em sua Região Metropolitana.

A água aparece no capítulo 18 da Agenda 21 Global como elemento importante para a manutenção dos ecossistemas terrestres e hidrosfera, ao mesmo tempo em que são indicados problemas quanto ao uso inadequado, poluição de mananciais, escassez e finitude.

Em janeiro de 1992 aconteceu em Dublin - Irlanda, a Conferência Internacional sobre a água e Meio Ambiente, com a Declaração de Dublin sobre Água e Desenvolvimento Sustentável com orientações que devem ser tomadas em nível internacional, nacional e local. 
Entre os princípios da Declaração de Dublin destacam-se os seguintes:

- A água doce é um recurso finito e vulnerável, essencial para sustentar a vida, o desenvolvimento e o meio ambiente.

- O desenvolvimento e gestão da água devem ser realizados sob uma abordagem participativa, envolvendo usuários, planejadores e formuladores de políticas em todos os níveis.

- A mulher tem um papel central na provisão, gestão e conservação da água.

- A água tem um valor econômico para todos os usos e deve ser reconhecida como um bem econômico (WMO 1992).

Também são estabelecidas algumas propostas de ações para que se garanta os princípios estabelecidos, entre eles: priorizar o saneamento básico e combate a fome das nações excluídas; planejar ações contra desastres naturais; conservar e reutilizar a água; promover o desenvolvimento sustentável urbano; uso racional da água na produção agrícola e rural; proteger os ecossistemas aquáticos; resolver conflitos relacionados á água; fortalecer a estrutura de gerenciamento hídrico e de desenvolvimento sustentável; capacitar recursos humanos (WMO 1992).

O Brasil instituiu a Política Nacional de Recursos Hídricos em 1997 e criou o Sistema Nacional de Gerenciamento de Recursos Hídricos definindo novos rumos para a gestão das águas, entre eles a adoção da bacia hidrográfica como unidade territorial para a implementação da nova legislação.

A situação dos recursos hídricos em São Paulo merece atenção uma vez que está localizado na Bacia Hidrográfica do Rio Paraná, responsável por $6 \%$ da produção de água doce nacional, porém a Região Sudeste possui a maior densidade demográfica do país com 78,33 habitantes $/ \mathrm{km}^{2}$ ( REBOUÇAS 1999; IBGE 2000aำ citados por MARCON 2005). 
Em 1996 e 1997 a Região Metropolitana de São Paulo sofreu com a escassez de água e a possibilidade de black-outs que levaram a uma série de medidas como racionamento de água e campanhas para uso racional, reuso e economia do recurso água.

Portanto, a proposta de elaboração de um projeto de Agenda Ambiental a partir do tema água foi uma estratégia de educação ambiental bastante oportuna. Foi acompanhada da elaboração do material didático "Água hoje e sempre: consumo sustentável' especialmente formatado para subsidiar metodologicamente $\mathrm{o}$ trabalho interdisciplinar e transversal sobre 0 tema. Pretendia-se com esse projeto:

Subsidiar a escola a inserir a temática ambiental no projeto pedagógico, de forma transversal e interdisciplinar, para ampliar e dar continuidade aos projetos bem-sucedidos na escola.

Fornecer documentos informativos aos técnicos e professores para que adquiram novos conhecimentos sobre a questão ambiental, propiciando a autonomia profissional para enfrentar os novos desafios educacionais na sociedade contemporânea.

Auxiliar os professores na realização de atividades investigativas de cunho socioambiental com os alunos, com ações voltadas à transformação de suas realidades, tendo como eixo norteador o desenvolvimento de competências e saberes de suas áreas de conhecimento que integram a Educação Básica.

Contribuir para a implementação do programa de uso racional de água nas escolas, por meio de sensibilização na formação de técnicos pedagógicos, equipe escolar, alunos e comunidade para que a escola seja um espaço de mobilização dessa comunidade.

Para a realização desses objetivos na Escola, é essencial o trabalho reflexivo e propositivo de sua equipe pedagógica e administrativa, que, com o estudo do material, poderá adequá-lo à sua realidade, às demandas e às características locais. Neste processo, é fundamental garantir a busca dos melhores resultados para sua própria comunidade, na perspectiva de mudanças efetivas em relação ao uso sustentável da água 
(SEE/CENP 2004 p.11).

A publicação trouxe orientações quanto a realização de projetos interdisciplinares em meio ambiente para os três níveis do ensino básico e foi organizada com atividades para as diferentes disciplinas e com os objetivos específicos em cada etapa.

Para o Ensino Fundamental I - EF I ( $1^{1^{a}}$ à $4^{\text {a }}$ séries), Fundamental II EF II (5 a $8^{\mathrm{a}}$ séries) e Ensino Médio (EM) foram elaboradas propostas para matemática, arte, geografia, história, educação física, ciências (EFI E EF II) ou biologia $(E M)$, língua portuguesa e matemática por meio dos seguintes projetos:

1. Uso cotidiano da água

2. Água: de onde vem, para onde vai ?

3. Rios da Cidade

Como nos outros projetos da CENP aconteceram reuniões com os Assistentes Técnicos Pedagógicos (ATPs) de todas as Diretorias de Ensino (DE) do Estado, para a apresentação do projeto, orientação técnica e entrega do material em novembro de 2004.

Os ATPs funcionam como multiplicadores em suas respectivas Diretorias de Ensino (DE), convocando os professores para orientá-los e esses, por sua vez, levam os projetos para as escolas. Na DE Jundiaí foram convocados professores de ciências, biologia e geografia para os cursos de capacitação sobre o projeto.

Aconteceram dois encontros: no primeiro em novembro de 2004, foi entregue o material didático e realizada uma oficina para a elaboração de projetos interdisciplinares; no segundo, em março de 2005, o tema foi Agenda 21 Global e Agenda Ambiental na Escola.

Nas unidades escolares, os professores participantes das reuniões de capacitação deveriam dar continuidade ao trabalho, orientando os colegas 
com o apoio do professor coordenador e dos ATPs da Oficina Pedagógica. Essas reuniões deveriam atender às necessidades específicas de cada escola e da sua comunidade, garantindo que o processo acontecesse de forma construtiva, coletiva e interdisciplinar.

Cada unidade escolar recebeu 10 exemplares do livro "Água hoje e sempre: consumo sustentável' para apoio didático-metodológico. O professor coordenador pedagógico ficou com a função de fazer o registro do material para que a coleção não se perdesse.

Quanto às iniciativas do Ministério da Educação e do Ministério do Meio Ambiente com relação à iniciativas de promoção da educação para a sustentabilidade, o que tem sido percebido a partir das ações que chegam à escola é que existe uma ênfase na mobilização social e formação dos jovens para a participação em políticas, porém sem um aprofundamento teórico de questões determinantes dos problemas ambientais.

Em 2003 e 2005 os Ministérios da Educação e do Meio Ambiente enviaram para as escolas de Ensino Fundamental II (5 $5^{\underline{a}}$ a $8^{\underline{a}}$ série) um convite para participarem da Conferência Nacional Infanto-Juvenil de Meio Ambiente, cuja proposta era discutir na unidade escolar temas que podem gerar transformações com relação à melhoria da qualidade de vida. Os temas sugeridos para 2003 foram: como vamos cuidar da água, dos seres vivos, dos nossos alimentos, da nossa comunidade, da nossa escola. Os tremas para 2005 foram os acordos internacionais, entre eles: Mudanças Climáticas, Biodiversidade, Segurança Alimentar e Nutricional e Diversidade Étnico-Racial.

As discussões deveriam seguir uma metodologia de levantamentos de problemas em nível global, nacional e local, e encaminhamentos de sugestões, realizando no final do processo uma Conferência na escola. Cada escola deveria escolher um representante para a Conferência Nacional Infanto-Juvenil de Meio Ambiente que aconteceu em Brasília, com alunos escolhidos nos Estados. 
Em 2005 as escolas receberam uma cartilha com sugestão para a formação de uma Comissão de Meio Ambiente e Qualidade de Vida nas escolas, o Com-Vida; e para realizar a Agenda 21 na Escola.

Nessas iniciativas citadas, não estão sendo percebidas ações voltados para a formação do professor. Considerando-se que o professor e as equipes gestoras têm um papel crucial na deflagração de ações democratizantes e transformadoras, não considerar essa questão pode levar ao seu esvaziamento, ou a perderem-se oportunidades de incremento efetivo de qualidade à educação básica.

A proposta de construir a Agenda 21 na escola pressupõe a práxis da educação ambiental enquanto prática política, formadora de valores e competências para a transformação da realidade.

O desafio de construir a Agenda 21 na escola é o de buscar uma sociedade sustentável por meio da participação, do questionamento, da organização de ações e planejamento de metas para a vida da escola, do bairro, da cidade, e do planeta.

O desafio de construir a Agenda 21 na escola é sair da ordem estática da sala de aula enquadrada pela lousa e "pular" o muro para participar do cotidiano da vida da comunidade.

O desafio da construção da Agenda 21 na escola é utilizar-se de uma estratégia metodológica para compartilhar os conhecimentos científicos, de mundo, de vida sem fronteiras entre eles.

\subsection{REGIÃO DE JUNDIAÍ - ÁREA DE ESTUDO}

Jundiaí localiza-se entre as cidades de São Paulo e Campinas. Dista 49 quilômetros de São Paulo pela Via Anhanguera e 37 quilômetros de Campinas, pela mesma rodovia. 
Tem uma população de 346.172 habitantes com densidade demográfica igual a 769,27 habitantes $/ \mathrm{km}^{2}$. A cidade encontra-se na $14^{\text {a }}$ posição de IDH, entre os 5.507 municípios brasileiros e 4⿳亠丷a posição no Estado de São Paulo, entre 645 municípios, e $2^{a}$ posição no estado de São Paulo, entre os municípios com mais de 200.000 habitantes (PMJ, 2006).

As cidades médias, como Jundiaí foram polarizadoras do destino de grande parte da população excluída da área rural brasileira, alterando o destino final que eram as grandes metrópoles, até a década de 1980. O êxodo rural das últimas décadas foi conseqüência não somente do desenvolvimento do setor industrial, mas também da fuga do trabalhador rural devido às péssimas condições de trabalho e vida no campo. Só na década de 1980, 18 milhões de trabalhadores rurais migraram para as cidades (ALVES, 1992).

No Estado de São Paulo a Lei Estadual 9866/97, incorporou princípios da Lei estadual 7633/91 e da lei 9433/97, que institui a Política Nacional dos Recursos Hídricos. Estas Leis implantaram um novo sistema de gestão onde a bacia hidrográfica é considerada como unidade de gestão (MARCON, 2005). Nessa nova política a participação da Sociedade Civil é resgatada através os Comitês de Bacias, os quais são colegiados democráticos compostos por representantes de órgãos Estaduais, dos Municípios e da sociedade civil organizada.

Jundiaí e Louveira são cidades limítrofes e pertencem à mesma Unidade de Gerenciamento de Recursos Hídricos - UGRHI 5, formada pelos Rios Piracicaba, Jundiaí e Capivari.

A região UGRH 5, apresenta-se como o principal destino do processo de desconcentração econômica da região Metropolitana de São Paulo, com crescimento demográfico acelerado, pequena parcela do esgoto urbano tratado, e com áreas irrigadas que demandam grande volume de água (MARCON, 2005).

Hoje a cidade conta com um Programa de Recuperação da Qualidade das Águas da Bacia do Rio Jundiaí, que, entre outras realizações, implantou um sistema de coleta e tratamento de esgotos domésticos da ordem de 
95,08 \% e 97\% respectivamente; o que reduziu drasticamente a poluição da Bacia do Rio Jundiaí (PMJ, 2006).

A cidade de Louveira está localizada ao norte da cidade de Jundiaí, e tem população de 23.970 habitantes. O município não possui tratamento de esgoto, sendo este lançado in natura, ou seja, sem qualquer tipo de tratamento no Rio Capivari.

Nesse contexto, a gestão dos recursos hídricos na região tornou-se uma questão preocupante e urgente.

A Agenda 21 escolar pode ser um instrumento de efetiva transformação trazendo para o cotidiano escolar as questões imperativas da realidade, como por exemplo, a água.

Pelos desafios que a construção da Agenda 21 escolar pode levar a superar, apresento a seguir os objetivos que esse trabalho procurou atingir: 


\section{OBJETIVOS}

\subsection{OBJETIVO GERAL}

Analisar e descrever o processo de construção da Agenda 21 nas escolas públicas estaduais da Diretoria de Ensino de Jundiaí, a partir da proposta pedagógica da CENP "Água Hoje e Sempre: Consumo Sustentável”.

\subsection{OBJETIVOS ESPECÍFICOS}

- Identificar e registrar os conhecimentos e práticas dos professores sobre as questões ambientais.

- Descrever as representações sociais dos educadores sobre: meio ambiente e Agenda 21 .

- Analisar as transformações ocorridas nas escolas a partir do processo desencadeado pelo projeto.

- Propor encaminhamentos que possam colaborar com a construção da Agenda 21 Escolar. 


\section{METODOLOGIA}

\subsection{METODOLOGIA QUALITATIVA}

Embora o trabalho tenha sido realizado em escolas públicas de uma área bem delimitada, o cotidiano das escolas é bastante variável, conforme será descrito na apresentação dos resultados. O questionamento envolve a compreensão do significado da prática pedagógica os elementos subjetivos são extremamente importantes para o encaminhamento e para a conclusão do presente estudo.

Dessa forma, a metodologia utilizada foi a qualitativa pois propicia melhor compreensão tanto dos aspectos objetivos como subjetivos das diferentes realidades encontradas nas escolas no que se refere à valores, atitudes e opiniões dos sujeitos entrevistados (MINAYO, 2000).

Para LÜDKE e ANDRÉ (1986) citando Bogdan e Biklen (1982) ao conceituar a pesquisa qualitativa em educação, esta deve ter 0 ambiente natural como fonte direta de dados, o contato direto e prolongado do pesquisador com o ambiente e a situação que está sendo investigada a fim de conseguir captar a perspectiva dos participantes.

O presente estudo, por tratar de uma ação educativa que envolve inúmeras variáveis, buscou, dentro da pesquisa qualitativa, uma abordagem etnográfica mais voltada para as pesquisas em educação, pensando no ensino e na aprendizagem dentro de um contexto cultural amplo, com a preocupação de entender como se relaciona a realidade com o que se faz na escola. 


\subsection{POPULAÇÃO ALVO}

Foram considerados para o desenvolvimento do presente trabalho os professores das escolas da Rede Pública Estadual da Diretoria de Ensino de Jundiaí.

A Diretoria de Ensino de Jundiaí faz parte da Coordenadoria de Ensino do Interior da Secretaria de Educação do Estado de São Paulo sendo responsável pela administração das escolas particulares e públicas da região.

A rede de escolas públicas é formada por 75 Unidades Escolares (UE) locadas nos municípios de Campo Limpo Paulista (7 escolas), Itatiba (4), Itupeva (6), Jarinu (5), Jundiaí (36), Louveira (4), Várzea Paulista (13), totalizando 3122 professores entre efetivos (1852) e contratados (1270) (SEE - DRHU / dez 2005).

Foram ouvidos professores das escolas dos municípios de Jundiaí (34) e Louveira (4), totalizando 38 escolas distribuídas por todos os bairros das duas cidades (anexos 1 e 2), e 296 professores no total, sendo 270 e 26 , respectivamente de cada cidade.

Optou-se por estudar as escolas dessas duas cidades por sugestão da Diretoria de Ensino que informou que a implantação da Agenda 21 na cidade de Louveira estava acontecendo de forma positiva, uma vez que as escolas estaduais, juntamente com as municipais, conseguiram desenvolver trabalhos ao longo do ano voltados para a construção da Agenda 21 Local que mobilizou os alunos e professores na busca de soluções para problemas locais, tendo os seus resultados apresentados num Fórum que visava também a troca de experiências. 


\subsection{INSTRUMENTOS DE PESQUISA}

\subsubsection{Grupo Focal}

A estratégia de grupo focal parece ser a mais indicada para o trabalho com um grupo pequeno de professores nas escolas. Para IERVOLINO e PELICIONI (1998) o grupo focal é uma técnica de pesquisa qualitativa que utiliza sessões grupais, sendo um dos fóruns facilitadores da expressão de percepções, crenças, valores e atitudes sobre uma questão específica.

A escolha do grupo focal como instrumento de coleta de dados foi definido a partir da intenção de ouvir a opinião dos professores em uma situação onde pudessem discutir as questões da forma mais espontânea possível.

Para a coleta de informações por meio dos grupos-focais foram anunciadas aos professores explicações a respeito do motivo da pesquisa, a condição de anonimato e a expectativa de que esse estudo possa contribuir para a melhoria da qualidade de vida na escola, no bairro, na cidade e em última instancia no mundo; condições essas que efetivamente criaram um clima propício para a coleta de informações, conforme propõe MINAYO (2000).

As reuniões do grupo-focal foram realizadas nas escolas durante 0 horário de HTPC (Hora Trabalho Pedagógico Coletivo) quando os professores realizam trabalhos voltados para o estudo, planejamento, troca de informações de práticas pedagógicas junto com os professores e coordenadores.

Os HTPCs tem duração de 2 a 3 horas semanais constituindo a jornada de trabalho dos professores. Para um professor com jornada semanal até 24 aulas é obrigatória a participação em duas horas de trabalho pedagógico coletivo semanal. Para professores com jornada acima de 25 
aulas é obrigatório o cumprimento de 3 horas HTPC por semana. As reuniões são orientadas pelo Professor Coordenador Pedagógico.

Foi realizado um pré-teste com um grupo de professores, para verificar a adequação do roteiro de trabalho do grupo focal. Para KIDDER (1987) esse procedimento é indicado para resolver problemas quanto à adequação do instrumento, orientando mudanças necessárias quanto à sua formulação.

\subsubsection{Análise documental}

Para LÜDKE \& ANDRÉ (1986, p.38), citando Philips (1974, p.187), são considerados documentos "quaisquer materiais escritos que possam ser usados como fonte de informação sobre o comportamento humano".

A análise documental do material produzido pelos professores, foi feita em diferentes momentos e com documentos produzidos pelos professores e pelos alunos.

Esta análise documental baseou-se em dois tipos de documentos: primeiramente o projeto elaborado coletivamente pelos professores de diferentes escolas, numa oficina realizada na Diretoria de Ensino, a partir das orientações e material distribuído pela CENP num primeiro encontro, em novembro de 2004; depois os projetos enviados à Diretoria de Ensino a partir da solicitação da mesma que orientou desde o primeiro encontro que cada escola deveria elaborar o seu projeto pedagógico voltado para a implantação da Agenda 21 Escolar, no ano de 2005. Logo, esse projeto também constituiu-se como documento de análise que contou com 0 referencial teórico do livro "Água hoje e sempre: consumo sustentável” .

Esses relatórios foram apresentados à DE em junho de 2005. 


\subsubsection{Entrevista}

É um instrumento básico de coleta de dados a partir da interação entre entrevistador e entrevistado.

Segundo LÜDKE e ANDRÉ (1986, p.34) “(...) a entrevista permite a captação imediata e corrente da informação desejada, praticamente com qualquer tipo de informante e sobre os mais variados tópicos".

As entrevistas foram aplicadas nos casos em que não foi possível realizar os grupos focais em função da indisponibilidade dos professores ou da não aceitação em participar das reuniões. As entrevistas foram aplicadas em apenas duas escolas, e seguiram o mesmo roteiro do grupo focal.

Foi entrevistada também a Coordenadora de Projetos da Coordenadoria de Estudos e Normas Pedagógicas (CENP) da Secretaria de Estado de Educação de São Paulo com a finalidade de complementar informações relativas à implementação do Projeto "Água hoje e sempre: consumo sustentável" e Agenda 21 nas escolas.

A apresentação dos resultados e análise dos três instrumentos de pesquisa foi realizada conjuntamente, na tentativa de buscar os princípios subjacentes aos trabalhos e projetos desenvolvidos na escola sobre a temática ambiental, e de situá-los num contexto mais amplo, conforme orientam LUDKE e ANDRÉ (1986) para as pesquisas qualitativas que pretendem realizar uma abordagem etnográfica.

Segundo MINAYO (2005) a análise conjunta de dados obtidos a partir de diferentes instrumentos de pesquisa permite a complementação dos dados e denomina-se triangulação.

Dessa forma, foi possível identificar aspectos relevantes quanto ao objeto de estudo a partir do depoimento dos professores e dos documentos oficialmente entregues à $\mathrm{DE}$. 


\section{RESULTADOS E DISCUSSÃO}

Apresentam-se a seguir os resultados obtidos com as reuniões de grupos focais, entrevistas e análise documental dos projetos elaborados a partir do tema Agenda 21 na Escola.

A coleta de dados foi realizada nos meses de outubro, novembro e dezembro de 2005.

Nos grupos focais foram ouvidos 280 professores e selecionadas as falas que, a partir dos referenciais teóricos adotados nesse trabalho, apresentaram maior relevância no sentido de configurarem representações sociais dos professores, considerando que as representações sociais sobre qualquer tema, tendem a reproduzir as noções do senso comum circulantes na sociedade (MOSCOVICI, 1978).

O número de participantes dos grupos focais teve grande variação, pois a constituição dos mesmos dependeu da aceitação de convite por parte dos professores, uma vez que a participação deve ser livre.

Em apenas 2 das 38 escolas pesquisadas não foi possível realizar as reuniões de grupo-focal pois a direção não autorizou o trabalho alegando a impossibilidade em disponibilizar o horário de HTPC para finalidade diferente da estipulada ou em função da impossibilidade de agendamento compatível.

Em uma escola a reação dos professores foi negativa ao convite para participar da discussão, inviabilizando o emprego da técnica de grupo focal em função da participação de apenas 2 professores. Nesse caso, e nas escolas onde o número de professores disponíveis para a realização da pesquisa não completou no mínimo 6 participantes, foi realizada entrevista seguindo o roteiro de perguntas do grupo focal (anexo 3 ).

$\mathrm{Na}$ maioria das escolas a proposta de participar de uma pesquisa sobre o tema Agenda 21 na Escola foi muito bem recebida, com a integração 
e envolvimento necessários entre o moderador e o grupo de professores. Os professores explicitaram a necessidade de serem ouvidos sobre as suas angústias, incertezas, e a sua busca por alternativas didático-pedagógicas que efetivamente promovam o aprendizado dos seus alunos.

Os grupos focais foram organizados seguindo a dinâmica de primeiramente fazer o levantamento de informações para o diagnóstico, contemplando todo o roteiro previsto para o grupo focal e depois aconteceram intervenções atendendo aos interesses dos professores que participaram da pesquisa.

Essa intervenção consistiu numa explanação de trinta minutos a uma hora, com a apresentação da Agenda 21 Global, o livro da CENP "Água hoje e sempre: consumo sustentável”, publicações referentes a Agenda 21 Local e Escolar, além da contextualização do surgimento desses documentos diante da realidade do final do século XX.

A partir dessa troca de informações os professores puderam ter noções sobre como poderiam lançar mão da metodologia da Agenda 21 como um recurso importante para o seu trabalho pedagógico na busca de novos horizontes para o aprendizado.

Uma vez que o tempo disponível era escasso para as questões que surgiram a partir das discussões posteriores, os professores participantes dos grupos focais, solicitaram que nos cursos de capacitação fossem abordados temas que constam na Agenda 21 e mais detalhes sobre a metodologia de trabalho.

Mesmo os professores que utilizaram a publicação da CENP para o seu trabalho no ano de 2005, segundo os depoimentos, disseram que desconheciam a essência da Agenda 21 Global e também não utilizaram a propostas do capítulo final do livro - Agenda 21 na escola, por não terem tomado ciência ou não terem conseguido relacioná-lo à sua prática pedagógica. 
Uma vez que a maioria também não conhecia a publicação da CENP, os professores solicitaram aos coordenadores que a disponibilizassem para consulta.

Os resultados das escolas de Jundiaí e de Louveira serão apresentados separadamente, a partir da categorização proposta. A relação das escolas participantes da pesquisa aparece nos anexos 1 e 2 .

\subsection{AS ESCOLAS DE JUNDIAÍ}

\subsubsection{O trabalho com projetos}

Para os professores, os projetos representavam uma prática pedagógica diferenciada, que alterava a rotina de desenvolvimento do conteúdo curricular tradicional, prescindindo de criatividade, maior dedicação tanto discente quanto docente, e da busca do saber que não está somente nos livros didáticos, e nem se encerra numa disciplina, devendo portanto permitir uma atuação interdisciplinar.

Segundo COIMBRA (1985), citado por PHILIPPI JR, PELICIONI MCF, COIMBRA JDAA (2002)

\footnotetext{
a interdisciplinaridade é um processo de conhecimento que busca estabelecer vínculos intencionais entre os distintos ramos do saber, voltados à compreensão e explicação do universo da pesquisa, por meio da utilização de uma estrutura básica de formação multidisciplinar, superando assim a excessiva compartimentação científica provocada pela especialização das ciências modernas (p.179) .
}

Os projetos eram vistos como uma forma de trabalho na qual, obrigatoriamente, deveria existir um planejamento com objetivos e metas definidos, assim como um produto final concreto que deveria ser socializado com a comunidade escolar. Ainda que todo o processo de educação formal previsse essas etapas, os projetos corporificavam a necessidade de organização do trabalho docente de forma especial. 
Segundo os professores, os projetos deviam ser avaliados de forma diferente, uma vez que os conteúdos abordados são construídos e reconstruídos pelos alunos, demandando outras formas de avaliação.

O cotidiano tradicional com aulas expositivas e enfoque conteudista normalmente é avaliado por meio de provas que verificam a assimilação das informações transmitidas, enquanto nos projetos, a avaliação é qualitativa, pois considera além do cognitivo, outros saberes como as relações interpessoais, as diferentes habilidades e competências do aluno. Os professores relataram diversos casos de alunos tidos como indisciplinados e improdutivos em sala de aula, que tornaram-se destaques nos trabalhos com projetos pois tiveram oportunidade de mostrar outros saberes e participar do processo educativo ativamente.

Um grupo de professores analisou a iniciativa de uma professora de ciências, que apesar de não ser considerada como "projeto da escola", foi reconhecido pelos colegas como fator de mudança no comportamento dos alunos:

Prof. 1 "A professora de ciências fez uma horta desde o começo do ano, mas foi um projeto fechado, não foi interdisciplinar , não só por culpa da professora, mas por culpa nossa mesmo; eu mesma não tive interesse em ver; foram poucos alunos por sala (...) tudo o que é produzido na horta foi utilizado pra fazer alimentação para os alunos - bolo de cenoura, torta, pão - onde a professora explica o conteúdo de ciências: botânica, fermentação, etc. (...). As aulas são montadas em cima do que se está fazendo (...)".

Prof. 2 "Um aspecto do projeto que eu achei interessante, que mesmo não envolvendo todos os alunos, você não teve notícias que houve depredação, de que chegaram lá e estragaram tudo. A nossa comunidade tem uma série de problemas, assim como toda escola tem; e apesar deles não 
respeitarem uma plantinha do jardim as plantas da horta eles respeitaram, acho que é uma leitura que deve ser feita".

EE Beta 3

Das 34 escolas pesquisadas em Jundiaí apenas em duas os professores e a coordenação assumiram não desenvolver projetos, mas ter realizado "apenas trabalhos individuais" sem qualquer planejamento coletivo, orientação, e socialização dos resultados com a comunidade escolar; restringindo-se ao objeto de estudo da disciplina.

Nos dois casos os docentes relataram os problemas administrativos como responsáveis pelo mau desempenho na parte pedagógica, quer pela ausência ou pela indiferença do grupo gestor.

No depoimento a seguir pode-se perceber a representação de que a educação é o resultado de trabalho em equipe, sendo fundamental, a participação e a visão progressista dos gestores:

"Eu vejo que o sistema precisa sensibilizar os gestores das escolas, e eu falo genericamente, pra que isso ocorra também com os docentes (...)”. EE Beta 3

"Com a troca de direção, vem um, vem outro, nós não conseguimos um projeto para que ele possa ter andamento e continuidade, principalmente sobre meio ambiente (...). O que falta aqui é uma pessoa que organize, porque todo projeto tem que ter uma pessoa que organize”. EE Pi 5

$\mathrm{Na}$ escola existe um período destinado ao planejamento do ano letivo, no início das aulas, quando a equipe escolar reúne-se para definir metas para o trabalho educativo. Nesse espaço coletivo realiza-se a avaliação das experiências anteriores e o planejamento do trabalho futuro.

Numa gestão democrática, o planejamento deve ser feito de forma participativa de modo que todos os atores envolvidos (gestores, professores, funcionários, alunos, pais e comunidade) façam parte do processo, 
efetivamente, definindo as metas para o ano letivo, e as metodologias de trabalho correlatas.

Os projetos são concebidos nesse momento, e tomam forma ao longo do ano. A seguir os professores relatam essa experiência:

"Nos dias do planejamento (início do ano) nós ouvimos o que a escola propõe, quais as dificuldades, o que nós poderíamos fazer para melhorar em relação a escola. No segundo dia nós fomos separados por área, no meu caso, ficamos professores de história e geografia, bem como as outras áreas. Assim foi decidido o que cada área achava importante. Depois disso, lançamos no quadro todas as propostas de projetos, foi feita uma votação e saíram alguns projetos que a escola achou importante, depois outros que vieram da Diretoria de Ensino. A escola escolheu: Projeto Sifco, Meio Ambiente, Saúde e Vida e Incentivo à Leitura. A partir daí cada um por si, na sua disciplina, num certo momento, no bimestre, na sala que achar necessário, mas interdisciplinar e com a escola inteira envolvida não acontece ”. EE Gama 8

Existe um avanço no sentido de planejar as ações de modo coletivo e participativo, mas a manutenção do trabalho de forma integrada ainda é difícil pois exige um esforço muito grande por parte da coordenação e dos docentes, quer pela dificuldade em reunirem-se para um constante fortalecimento do processo, quer pelas carências na formação pessoal de cada professor dificultando a concretização de ações planejadas, ou ainda, pelas mudanças de rumos que ocorrem ao longo do percurso.

A seguir professores de uma mesma escola, porém de turnos diferentes, sob a mesma coordenação, relatam experiências bastante distintas quanto ao trabalho com projetos:

"Nós recebemos um comunicado, até a coordenadora passou pra nós a respeito de preservação ambiental, que nós tínhamos que fazer projetos dentro desse tema e cada um dentro da sua 
área foi fazendo o trabalho que achou que fosse necessário pra complementar essa conscientização. Cada professor fez o seu trabalho". EE Alfa 1 - professores do diurno

"Não, nós trabalhamos dentro de cada disciplina aquilo que nós entendemos como proteção à ecologia, mas nada assim: vamos fazer isso pra atingir aquele objetivo, tende a ser uma coisa bem de massa“. EE Alfa 1 - professores do diurno

"Sempre recebemos algumas idéias da Secretaria da Educação e baseado nessa idéia principal os professores fazem uma reformulação adequando à realidade da escola. Os professores se reúnem, todos dão idéias, a gente monta o projeto todos juntos, já vemos as disciplinas que vão participar, porque são interdisciplinares, e começa a colocar em ação".

\section{EE Alfa 1 - professores do noturno}

Essa desconexão entre a fala dos professores de uma mesma escola demonstra as diferentes percepções quanto ao trabalho pedagógico e especificamente quanto aos projetos. Independente de quais sejam os problemas vivenciados pela escola é imprescindível que exista uma unicidade que norteie o trabalho pedagógico conferindo-lhe uma identidade. Não é possível que o direito de ensinar livre e democrático se confunda com a rotina de cada um, permitindo que ele venha a fazer o que quer, e como quer. Cabe ao corpo gestor buscar essa coesão do trabalho em torno dos objetivos da escola, e do seu projeto político-pedagógico.

Em alguns casos os professores diferenciam os projetos que surgem na escola dos que são "enviados" pela Oficina Pedagógica.

"Alguns projetos partem dos professores e outros, como a Agenda 21, vêm da Diretoria de Ensino (...). Aí, de acordo com a escola nós montamos o que é prioridade pra escola, e então a gente começa pelo ambiente escolar (...). Aqui a reciclagem do lixo partiu da professora de ciências, o da água partiu da Diretoria de Ensino. Mas há uma certa resistência para esses 
projetos (os que vêm da Diretoria de Ensino) porque muitas vezes os professores têm um projeto e nós temos que parar no meio pra começar um que vem da Diretoria. Isso muitas vezes prejudica porque acaba não terminando nem um, nem outro (...), quando parte do professor como o nosso "Remexendo o Lixo", aí é diferente: há anos que ela (professora de ciências) está com esse projeto”. EE Pi 1

As Oficinas Pedagógicas constituem-se em instrumento executivo das diretrizes pedagógicas da Secretaria de Educação, de forma que todos os projetos propostos para as UEs fazem parte do planejamento desta. É inegável a importância e atualidade dos temas sugeridos, porém, há que se pensar em formas diferentes de abordagem dos docentes a fim de que as propostas de trabalho sejam significativas para a escola. Os professores precisam ser sensibilizados sobre a importância de uma determinada proposta, para que ela se concretize no trabalho docente.

Os professores e coordenadores indicaram com destaque a questão da descontinuidade dos projetos e a desarticulação das equipes docentes pela constante troca dos gestores e docentes nas escolas públicas.

Isso acontece, por um lado, pelo grande número de professores não efetivos que anualmente entram no processo de escolha de aulas, segundo a classificação por pontos baseada em tempo de serviço prestado na Secretaria de Educação do Estado. Atualmente a Secretaria conta com 100.021 professores efetivos e 105.318 não efetivos, totalizando 205.339 docentes no Estado (Cadastro Funcional / Departamento de Recursos Humanos / SEE, 26/12/2005). Esses dados devem ser alterados em função da nomeação de professores efetivos por meio de concurso público realizado em 2003 e que ainda está em vigor. Isso significa que até o momento mais de $50 \%$ dos professores não são efetivos nas escolas públicas do Estado de São Paulo.

Para que a escola pública tenha qualidade é necessário que existam condições objetivas de trabalho, o que envolve diversos aspectos, entre eles 
um quadro docente fixo. Com um quadro de professores que muda a cada ano é quase impossível garantir que se estabeleçam relações e equipes de trabalho. A educação é um processo, portanto pressupõe continuidade, caso contrário podem ficar lacunas ao invés de conhecimento. Outro ponto importante é a questão da construção de laços afetivos e do envolvimento do professor com seus alunos e a comunidade em que a escola está inserida, proporcionando um pertencimento e compromisso.

$\mathrm{Na}$ cidade de Louveira das 4 escolas estaduais pesquisadas, 3 contavam com um quadro em torno de $90 \%$ de docentes efetivos (dados de 2005 e projeção para 2006), consolidando-se a perspectiva de continuidade de trabalho, o amadurecimento das relações inter-pessoais e o envolvimento dos professores e grupo gestor com a escola.

\subsubsection{Projetos sobre Meio Ambiente}

Ao serem questionados sobre os trabalhos e projetos desenvolvidos nas escolas voltados para a temática ambiental, destacaram-se os seguintes relatos:

"A professora de ciências, que trabalhava conosco, ela agora não está mais na escola, desenvolveu um trabalho de meio ambiente (...)”. EE Gama 8

Foi muito significativa a representação de que os professores de ciências são os mais qualificados para o trabalho com meio ambiente. Em geral, durante as reuniões de grupos focais, os professores direcionaram a discussão para os colegas dessa disciplina e da biologia, justificando que normalmente eles eram responsáveis por desenvolver projetos voltados para esse tema, já sinalizando a representação "naturalista" do grupo.

A necessidade de uma abordagem abrangente sobre as questões ambientais vem sendo discutida e orientada internacionalmente. Desde 1968, quando a UNESCO (Organização das Nações Unidas para a Ciência 
e Cultura) a partir de um estudo comparativo em 79 países propôs o conceito de "ambiente" significando não apenas o entorno físico natural, mas também o meio construído e os aspectos sociais, culturais e políticos a ele relacionado.

No relato a seguir, uma das professoras demonstrou a sua preocupação com a imprecisão conceitual sobre meio ambiente que ela vivência.

"O aluno vai trabalhar com área degradada, e muitas vezes ela mora numa área degradada, ou ao lado de uma área em que a poluição está presente , e ele vai estudar a derrubada da Mata Amazônica, e os impactos na Taiga, coisa que não faz sentido (...). Ou as vezes ele mora dentro da Mata Atlântica, que é o caso que nós temos aqui e o professor vai falar de Mata Atlântica e eles não conseguem se perceber no próprio meio ambiente, por causa de uma alfabetização na área de meio ambiente (...) por falta de conhecimento e cultura em preservar o meio ambiente. Os projetos que eu conheço acabam na superficialidade (...)”. EE Alfa 1

"Da classe que tem dinheiro (alunos) para a classe mais desprovida de dinheiro não muda muito a visão sobre $o$ ambiente, porque os que não têm destroem o meio ambiente por uma questão de sobrevivência, os que têm destroem por uma questão de consumismo. Não acho que a questão econômica mude a visão que nós temos sobre meio ambiente. Pode mudar a forma de causar impacto sobre ele". EE Alfa 1.

Apesar das suas orientações terem sido incorporadas oficialmente nos Parâmetros Curriculares Nacionais (MEC, 1997), assim como na Política Nacional de Educação Ambiental (BRASIL, 1999), e a comunidade científica se empenhar na produção e na divulgação dos novos paradigmas, existem lacunas muito grandes entre a teoria, a legislação e a prática docente no 
ensino básico. As representações dos profissionais da educação pública, do ensino fundamental II e do ensino médio quanto ao meio ambiente e educação ambiental ainda estão longe do que se faz necessário para uma efetiva educação transformadora para a sustentabilidade. Dessa forma, ações relevantes que poderiam fazer parte de um planejamento estratégico, como propõe a Agenda 21, perdem a importância quando descoladas de um objetivo mais amplo.

A seguir um relato de professores que disseram não realizar projetos com a temática ambiental:

"Não, a escola não tem trabalhado com projeto sobre meio ambiente porque nós estamos tendo problemas muito sérios de ordem administrativa, que têm dificultado muito nosso trabalho docente". EE Alfa 5

Apesar dessa opinião unânime entre os professores, foi realizado na escola um trabalho que envolveu toda a comunidade sobre zoonoses urbanas e saúde pública, por meio de uma campanha informativa sobre os riscos que as pombas, entre outros animais, podem trazer à saúde humana.

A escola funcionava em um prédio amplo construído para o ensino médio, porém, com a diminuição da demanda de alunos no bairro, o número de funcionários também foi reduzido com a justificativa da manutenção do módulo padrão para a operação das escolas estaduais. Com isso, o serviço de limpeza e manutenção sofreu cortes e a escola foi infestada por pombas nos telhados e dependências internas do prédio, a ponto de uma aluna ser internada por infecção causada pela toxoplasmose transmitida pelos animais. Além da campanha aconteceu a retirada dos animais e a colocação de telas em todos os espaços ocupados pelas aves para impedir a reinstalação dos mesmos.

Nessa mesma escola uma das professoras ao ser questionada em relação a sentir-se ou não capacitada para trabalhar com meio ambiente, respondeu que: 
“(...) é fácil trabalhar com meio ambiente, até porque aqui (escola) é nosso meio ambiente. Não existe projeto que não entre meio ambiente (...)".

Existe uma incongruência entre a primeira e a segunda resposta. Num primeiro momento, ao responder que a escola não realizou projetos sobre meio ambiente, ficou claro que o ambiente escolar não fazia parte da representação de meio ambiente para alguns professores. Porém, em seguida a professora de ciências reconheceu o espaço escolar como "nosso meio ambiente".

Os resultados dos trabalhos mostraram que houve uma ação transformadora por meio da informação e aumento da consciência sobre a relação entre saúde e meio ambiente, porém as respostas mostraram a falta de diálogo e reflexão coletiva sobre as ações planejadas e as praticadas, provavelmente ocorridas em função dos problemas gestores.

Conforme solicitação da Oficina Pedagógica, as escolas encaminharam em junho de 2005 os projetos elaborados para a construção da Agenda Ambiental na Escola. Das 36 escolas do município, poucas atenderam a solicitação.

Entre os projetos voltados para meio ambiente os que apareceram com maior freqüência, de acordo com os professores, foram os relacionados aos temas: água, lixo, horta, saúde.

Água

Com exceção das 2 escolas que não desenvolveram projetos voltados para meio ambiente, e das escolas que não participaram dessa pesquisa, em todas as demais 32 unidades escolares da DE de Jundiaí o tema água apareceu como prioridade entre os projetos. Isso ocorreu graças ao direcionamento dado pela CENP para que esse fosse um dos projetos prioritários de 2005, tendo como subsídio a publicação intitulada "Água hoje e sempre: consumo sustentável". É função da CENP desenvolver estudos, 
pesquisar, orientar e coordenar o trabalho pedagógico com o intuito de aprimorar o desenvolvimento do ensino.

Em novembro de 2004, professores de ciências e geografia foram convocados pelas Oficinas Pedagógicas das Diretorias de Ensino Regionais para receberem as orientações da metodologia proposta pelo projeto e de que forma esta poderia colaborar para a construção de uma Agenda Ambiental na Escola, a partir de 2005. Cada escola recebeu 10 exemplares do livro para uso dos professores.

Uma segunda reunião de capacitação foi realizada em março de 2005, novamente para professores de ciências e geografia, aprofundando-se na proposta da Agenda Ambiental da Escola o tema da Agenda 21 Global.

Num terceiro encontro em junho os professores passaram o dia na APA da Serra do Japi e assistiram duas palestras: uma sobre o trabalho da empresa de água e esgoto da cidade e outra sobre o Plano Diretor de Jundiaí. No período da tarde os professores fizeram uma caminhada pelas trilhas da área de conservação.

Muitas das escolas já incluíam o tema água no Plano Escolar anualmente, outras só o fizeram em 2005 graças à proposta da CENP. Entre essas os professores destacaram a obrigatoriedade que se impõe para os projetos "mandados pela Diretoria de Ensino" mas que no momento solicitado não se configuravam em propostas de trabalho de interesse da unidade escolar, por diversos motivos, como se posiciona o professor a seguir:

“(..) Os prazos da Diretoria são muito curtos, em 15 dias tem que terminar um projeto, então pára-se um começa-se outro e não se faz nada direito; só mesmo os projetos do professor que conseguem caminhar um pouco melhor. Nós temos um planejamento anual, a semana de planejamento é no início do ano, mas no meio do caminho aparecem projetos pra ontem, e infelizmente, é pra inglês ver. Se faz correndo, monta o 
relatório, tira umas fotos e manda pra lá (Diretoria de Ensino)".

\section{EE Gama 8}

Existe uma representação negativa de muitos professores quanto aos projetos que são orientados pela Oficina Pedagógica e/ou pela CENP, por serem vistos como propostas alienígenas, normalmente anacrônicas e que demandam mais tempo e dedicação do professor, que já está engajado em outros projetos elaborados pela escola, a partir da problemática local.

Uma vez acatada as orientações hierarquicamente superiores, a execução dos projetos segue caminhos diversos. No depoimento a seguir, um grupo de professores relata a insatisfação com os resultados:

“(...) os projetos na escola estão sempre atrelados a cumprir metas e participar de premiações da Secretaria da Educação. Nós já ganhamos prêmios com vários projetos que desenvolvemos sobre meio ambiente; porém, nós não vimos mudanças nenhuma sendo incorporada à nossa comunidade, que é bastante carente. Trabalhamos o ano todo sobre a qualidade da água, mas o córrego que atravessa o bairro continua sujo, cheio de lixo e nada mudou. Nós não queremos mais ganhar prêmios, queremos ver mudanças e isso não tem acontecido." EE Beta 8

A escola tem realizado a sua função educativa no momento em que transmite conhecimento, porém a ampliação da prática pedagógica para além das fronteiras da sala de aula, buscando ações que possam transformar a realidade e efetivar-se como prática pedagógica essencialmente política, ainda parece estar distante. A preocupação do grupo era conseguir mudanças objetivas no córrego que percorre o bairro e que faz parte da vida dos alunos. Com relação a essa sensação de impotência, talvez falte aos professores o "empowerment" necessário para brigar pelos direitos a um meio ambiente saudável, para o qual a gestão pública demonstrou indiferença. 
É importante destacar que não existe obrigatoriedade na execução das propostas encaminhadas pela Diretoria de Ensino ou pela CENP, ficando a critério da escola acatá-las ou não. Porém, desde 2001 o Governo do Estado tem concedido bônus aos integrantes do Quadro do Magistério, regulamentado pelo Decreto № 49.365, de 9 de fevereiro de 2005, que considera a assiduidade, o envolvimento, a responsabilidade, a atualização profissional e indica no Artigo $4^{\circ}$ inciso II - d) "implementação de projetos/ações (...)" como um dos critérios para a elevação do bônus anual. Esse fator tem sido considerado no momento de planejamento e realização dos projetos propostos pela SEE.

Algumas equipes relataram ter realizado projetos interdisciplinares sobre água e Agenda 21 na Escola, como foi solicitado pela Oficina Pedagógica. Porém, ao aprofundar a discussão e analisar os resultados dos projetos observou-se que os mesmos aconteceram de forma multidisciplinares e não interdisciplinares.

Existe uma grande diferença, que ainda não é de domínio dos docentes com relação aos conceitos de abordagem multi, inter e transdisciplinar. Ao analisar a fala e os projetos apresentados pode-se perceber que todos os trabalhos foram multidisciplinares. Existe uma diferença muito grande em se dividir tarefas e cada disciplina, dentro do seu limite, trabalhar o tema água e realizar um trabalho conjuntamente com troca de saberes entre os professores para que todos possam contribuir com uma discussão mais aprofundada sobre os recursos hídricos.

Exemplificando: em alguns casos a escola fez apresentação teatral coreografando uma música, o professor de português leu poesias e os alunos fizeram paródias com o tema água, o de ciências fez maquetes sobre o percurso de um rio e o de matemática construiu gráficos com garrafas plásticas demonstrando a disponibilidade de água no planeta. Todas as apresentações foram muito bem ensaiadas e os trabalhos muito bem feitos, porém não existiu interdisciplinaridade, pois não houve uma síntese dos vários aspectos que permeiam o tema água de forma integrada. Como 
esperar que o aluno seja capaz de perceber as inter-relações desse tema nas diferentes disciplinas e de que forma elas se dão no contexto ambiental em que ele vive, se nem mesmo os professores tiveram condições de fazêlo?

A maioria dos resultados foi essencialmente teórico restringindo-se a confeccionar cartazes, informar sobre os problemas dos recursos hídricos, discorrer sobre acidentes ecológicos, apresentações teatrais, musicais, carecendo de profundidade de análise e reflexão sobre a complexidade de fatores envolvidos com a questão.

Apenas em algumas escolas aconteceram ações mais diretamente relacionadas ao cotidiano do aluno, como na EE Conde do Parnaíba, uma das mais antigas de Jundiaí, realizou um projeto de construção da Agenda 21 a partir da revalorização da escola enquanto espaço de vivência e patrimônio histórico da cidade. O trabalho foi premiado na DE de Jundiaí e na SEE, conseguindo em função disso, verba para reformar e restaurar a escola que faz parte do patrimônio histórico da cidade completando 100 anos em 2006.

Outro caso, a EE Prof. Francisco Napoleão Maia também premiada com o Projeto Ecocarga desenvolvido em parceria com o Departamento de matemática da UNICAMP. O projeto foi realizado na disciplina de matemática a partir do estudo do consumo de água nas residências e na escola, apresentando como forma de redução a reutilização da água de esgoto para gerar energia em pequenos sistemas, como uma casa ou uma escola. A discussão foi feita a partir da busca de soluções sustentáveis para os recursos hídricos a partir da realidade e com participação ativa dos alunos até a construção de um protótipo que funcionou muito bem.

\section{$\underline{\text { Resíduos Sólidos }}$}

Por resíduos sólidos, segundo a definição adotada pela Agenda 21 Global, no Capítulo 21 "compreendem todos os restos domésticos e resíduos não perigosos, tais como os resíduos comerciais e institucionais, o 
lixo da rua e os entulhos de construção" (CNUMAD, 1997, p. 419). Os resíduos sólidos, ainda denominados pela maioria dos professores como "lixo", aparecem nos projetos pedagógicos, ou nos trabalhos, da seguinte forma: 1. em informativos: baseados em pesquisas e produção de cartazes e folhetos; 2. na reciclagem: confecção de objetos a partir de materiais recicláveis; 3. na coleta seletiva.

No depoimento a seguir, a coordenadora relatou de que forma a temática ambiental, e especificamente os resíduos sólidos, mesmo sem estar explicitada, permeia a proposta pedagógica da escola:

"A proposta pedagógica tem 3 metas principais: 1. diminuir a retenção e a evasão; 2. competência leitora; 3. discernir valores. Nessas metas os projetos entram, então eu consigo discernir valores trabalhando meio ambiente - o que é certo, o que é errado; jogar lixo no lixo; ao mesmo tempo eu estou trabalhando competência leitora, porque ele estará lendo um texto". EE Gama 8

Os trabalhos informativos apareceram em muitas escolas e em todas as séries do Ensino Fundamental e Médio. Cartazes e folhetos produzidos mostravam paisagens de natureza com rios, árvores e flores em contraposição a ambientes com acúmulo de resíduos sólidos, enfatizando a representação de meio ambiente limpo como natureza idealizada e longe do seu espaço de vivência, quer seja a escola, o bairro, ou a cidade.

Outros trabalhos realizados sob a orientação de professores de ciências enfatizaram o tempo de decomposição de diferentes produtos e do direcionamento dos mesmos para receptores de lixo nas cores convencionais usadas para a reciclagem: vidro-verde, papel-azul, plásticovermelho, metal-amarelo.

Em muitas escolas era feita a reciclagem de sucata pelas professoras de arte, transformando garrafas plásticas, papel, papel de balas, e outros, em objetos decorativos, utilitários, e papéis reciclados. A seguir, um relato 
que demonstra a insatisfação com a abordagem que foi dada à questão dos resíduos sólidos na escola:

"Eu como professora de arte fico com aquela impressão de que você tem que fazer uma oficina de papel. Tudo bem, mas a gente percebe que é algo muito mais grave, muito mais sério e profundo que não é só pra fazer um projetinho na escola tem que fazer parte da vida, que nós precisamos ter mais conhecimento pra estar desenvolvendo esse tema. Eu não tenho nem idéia”. EE Alfa 1

Algumas escolas realizaram campanhas e gincanas para arrecadação de papel e/ou latas de alumínio, com a finalidade de orientar a coleta seletiva e vender os produtos recicláveis para transformá-los em dinheiro. Em uma delas, a participação dos pais e alunos é relatada como de muito sucesso, e o retorno financeiro viabilizou a compra de equipamentos didáticos que a escola não possuía, melhorando a qualidade das aulas graças aos recursos audio-visuais. Na outra experiência, de igual envolvimento, foi possível a realização de um churrasco de confraternização entre alunos, pais e grupo docente, também alcançando os objetivos elencados no projeto. Ambos terão continuidade no próximo ano letivo (2006).

Nessas escolas o espaço escolar é bastante agradável, limpo, sem pichações e bem organizado. Porém, em outras unidades que também responderam ter trabalhado com reciclagem, mas na forma informativa e sem o envolvimento da comunidade e sem a visibilidade de uma ação transformadora, o resultado foi bem diferente:

"Nós começamos a falar da educação na sala de aula, como espaço dele (aluno) que precisa estar limpo, no outro dia era pra estar tudo limpinho. Nós orientamos, mas eles não mudam a atitude. Acho que a mudança de hábito é longa, se conseguirmos atingir $1 \%$ acho que devemos agradecer a Deus”. EE Alfa 1 
Parece oportuno lembrar das palavras de Paulo Freire sobre a desarticulação entre a teoria e a prática docente: "a reflexão crítica sobre a prática se torna uma exigência da relação teoria/prática sem a qual a teoria pode ir virando blábláblá e a prática ativismo (...), ensinar não é transferir conhecimento, mas criar as possibilidades para a sua produção ou a sua construção" (FREIRE, 1996, p. 22). Esse descolamento entre teoria e prática pode ser responsável pelo ciclo vicioso entre desinteresse do aluno e desestímulo do professor gerando uma situação onde ocorre a banalização da ação pedagógica e conseqüentemente da educação.

Ações como campanhas para coleta e reciclagem devem ser cuidadosamente direcionadas, pois corre-se o risco de ao propor a reciclagem, estimular o consumo desnecessário no intuito de cumprir as metas da gincana. Essas ações, quando praticadas isoladamente como atividades educativas são importantes, "porém, deixam de atingir os seus objetivos maiores da Educação Ambiental se dissociadas de um processo que exige planejamento contínuo de construção de conhecimento, de formação de atitudes, de desenvolvimento de habilidades que resultem em práticas sociais positivas e transformadoras" (PHILIPPI JR E PELICIONI, 2002, p. 5).

É importante que a escola diversifique o trabalho com o intuito de sensibilizar o aluno sobre a questão do lixo, porém, é fundamental que sejam agregadas a esse despertar o conhecimento e a reflexão sobre a relação entre a quantidade e qualidade dos resíduos e o modo de vida da sociedade de consumo, no sentido de possibilitar a mudança de atitudes para padrões sustentáveis de consumo.

Saúde

Foram realizados alguns trabalhos sobre Saúde nas disciplinas de Ciências e Português, relativos ao controle de doenças contagiosas, principalmente as Doenças Sexualmente Transmissíveis - DST, alimentação saudável, o saneamento como forma de garantir condições essenciais à saúde, porém, em nenhum momento essas ações foram relacionadas ao 
capítulo 6 da Agenda 21 Global que trata da Proteção e Promoção das Condições da Saúde Humana. Esta desconexão entre as ações propostas e realizadas num contexto mais amplo de forma a possibilitar ao professor compreender a sua ação local num processo que tem como fundamentação a sustentabilidade em um nível global, faz com que ações importantes pareçam pequenas e sem muita expressividade.

"Nós fizemos alguns trabalhos sobre saúde e vida - qualidade de vida, então entra meio ambiente, longevidade, prevenção, alimentação saudável, exercícios físicos (...)”. EE Gama 8

Essa professora se sente autônoma para desenvolver e aplicar trabalhos que envolvam o tema transversal saúde.

"O trabalho em meio ambiente tem sido realizado na escola há muito tempo, nós temos esse projeto Saúde e Vida esse ano, mas não em cima da Agenda 21. Existe um programa chamado $5 S$, que não foi um parceiro que nós arrumamos, não tem nada a ver com a escola, com o Estado; onde ele faz um trabalho de mudança de atitude". EE Gama 8

4.1.2 Capacidade para desenvolver temas relacionados ao meio ambiente

Novamente os professores de Ciências tomaram a liderança e responderam de forma unânime que se sentem preparados para desenvolver o tema, seguidos dos professores de Geografia. Os demais se sentem à vontade para discutir âmbito do senso comum, porém sem muita profundidade.

"Sim, eu me sinto capacitado para trabalhar com meio ambiente, porque é fácil trabalhar com meio ambiente, até porque aqui (a escola) é nosso meio ambiente. Não existe nenhum projeto que não entre meio ambiente. Estando tudo funcionando na escola, é meio ambiente, ter uma secretaria 
que funcione, pais participantes, alunos interessados".EE Alfa 5

"Nós por sermos seres humanos já somos até capacitados demais para falar sobre isso, porque a preocupação é nossa, não é isolada é mundial, nós já temos experiências pra passar até pro aluno o que é preservar". EE Alfa 1

"Eu acho que preparados todos nós estamos, as questões de meio ambiente a gente vê na televisão direto (...)”. EE Alfa 1

"Nós estamos sempre buscando informações, nós nunca sabemos tudo, é bem difícil porque é um tema muito abrangente. Uma coisa que está facilitando é que hoje é modismo, todo mundo fala a respeito de meio ambiente, fala a respeito de preservação, de reciclagem (...) e você acaba incluindo na sua aula como uma coisa nova, como uma curiosidade que acaba ficando melhor, mais ilustrada (a aula)".

\section{EE Alfa 6}

"Eu sou professora de português e acho que tem alguns temas que nós não estamos preparados pra responder porque falta um pouco de conhecimento, mas nada impede que a gente vá em busca dessas informações, como eu fiz quando eu fui questionada. Nós falamos de ciências, porque nós achamos que o professor de ciências está mais por dentro, mais interado, mas acho que ainda falta abrir pra outras disciplinas também esse tipo de capacitação”. EE Gama 8

"Não, eu acho que tenho muito a aprender". EE Gama 5

Para outros docentes existe a representação de meio ambiente como um tema que requer vários saberes, mostrando disponível para possíveis trocas de conhecimentos com outros colegas, embora se ressintam pela falta de tecnologia disponível para a melhoria da qualidade do seu trabalho. 
"Eu sou também professora de ciências, trabalhei na área, aprendi muito sobre meio ambiente coisas que foram significativas para atitudes que eu tenho hoje na minha vida, mas eu não me sinto capaz de dar aula de matemática, que é uma matéria estrutural, e tocar um projeto desse sozinha; mas se for interdisciplinar com um grupo que se comprometesse de fato, eu tenho certeza que teria condições de contribuir muito."

\section{EE Beta 3}

\subsubsection{Representações sobre Agenda 21}

Ao serem questionados sobre saberem ou não sobre a Agenda 21, a grande maioria dos professores respondeu a essa questão de forma negativa. A seguir, algumas respostas desse grupo sobre a idéia que eles faziam sobre 0 assunto:

"Não sei, mas acho que deve ser alguma coisa sobre meio ambiente, mas não sei exatamente". EE Alfa 5

"Eu acho que está relacionado à preservação da natureza, por causa do século 21, usar melhor os recursos da natureza, poluição, Aqüífero Guarani, que está sendo muito falado". EE

\section{Alfa 10}

"Acho que está relacionado com meio ambiente, poluição, cuidar do mundo, alguma coisa pra proteger o meio ambiente".

\section{EE Beta 6}

"A idéia que eu tenho é sobre preservação do meio ambiente".

\section{EE Alfa 8}

"Acredito que seja algum projeto interdisciplinar". EE Beta 2

"Eu acredito que seja pra ensinar as crianças e os jovens em geral, as questões prioritárias para a vida hoje e amanhã. Pra 
mim como pessoa, como cidadã, a minha maior preocupação é o que fazer com a água". EE Alfa 1

Outros professores responderam conhecer a Agenda 21, porém, superficialmente não se sentindo em condições de falar ou discutir sobre o tema. A seguir, algumas respostas desse grupo:

"Sim, Agenda 21 é o projeto sobre meio ambiente da Diretoria de Ensino relacionado ao projeto da água". EE Alfa 5

"Até o ano passado eu nunca tinha ouvido falar, aí um dia estava assistindo a TV Canção Nova e estava passando uma reportagem no nordeste com uma pessoa que trabalha com a Agenda 21. Então deu pra perceber que era algo ligado a meio ambiente, mas não sei exatamente o que é. Aqui em São Paulo eu nunca ouvi falar, ouvi nessa reportagem da Bahia”. EE Alfa 1

"Não tô trabalhando a Agenda $21 \mathrm{em}$ si, mas estamos trabalhando o lixo, a organização, todo mundo trabalha de uma forma ou de outra algum texto, organizando o espaço em que nós estamos por algumas horas". EE Pi 1

"A partir da Eco 92 foi elaborado um projeto em parceria com alguns países onde eles devem diminuir os poluentes". EE

\section{Beta 7}

"Eu sei mais sobre a Agenda 21 Escolar, como continuidade da conferência infanto-juvenil que aconteceu em 2003, onde as escolas se reuniram, escolheram umas das cinco perguntas para responder, escolheria um delegado, um representante, mobilizaria a comunidade, pais, funcionários e alunos, e teve uma devolutiva para o Estado. A Agenda 21 Escolar de 2005, veio com o título COM-VIDA e seguiria os mesmos critérios: mobilizar a comunidade, escolhendo um tema, fazendo as 
reuniões nas escolas, divulgando esse tema defendendo o meio ambiente. Isso não começou agora começou com a Eco 92". EE Beta 7

"Nós trabalhamos com qualidade de vida, ambiente foi o tema que nós trabalhamos. Nós ouvimos falar, sabemos que a foi implantado na Secretaria da Educação, mas a gente não trabalhou e não veio nenhuma explicação sobre esse trabalho pra nós". EE Gama 10

A representação dos docentes sobre Agenda 21 está relacionada a questão ambiental, qualidade de vida, preservação/conservação ambiental, água, lixo, poluição, enfim, uma diversidade de temas sempre ligados à Agenda 21 e que a mídia explora e divulga, ajudando a consolidar as representações das questões ambientais como problemas globais e urgentes. Porém, a Agenda 21 de modo geral, enquanto proposta de construção de ações estratégicas para a sustentabilidade social, ambiental, econômica, é uma grande desconhecida do professor de educação básica do Ensino Fundamental II e Ensino Médio nas escolas públicas da rede Estadual de Jundiaí. Apenas um professor relatou conhecer e ter pesquisado sobre a Agenda 21 Estadual para executar um trabalho em sua escola.

Para os professores que responderam conhecer a Agenda 21, as perguntas seguintes direcionaram a discussão para que esses pensassem, primeiramente, se a escola era um local adequado para a implantação da mesma, e em seguida, sobre a possibilidade de pensá-la (a Agenda) como uma estratégia de ensino na escola. A seguir, estão transcritas as opiniões desses docentes.

4.1.4 A escola como um local para a implantação da Agenda 21.

Embora exista a desinformação sobre a Agenda 21 e como ela poderia ser aplicada à escola, partindo do pressuposto que a escola é um 
ambiente de formação de cidadãos, ela seria um local ideal para laboratório, vivências, novos conhecimentos.

(...) a escola é onde o aluno está todo dia e traz a sua realidade pra nós podermos trabalhar a partir da vivência dele.

\section{EE Gama 9}

"Se a Agenda 21 estiver relacionada a preservação do meio ambiente, se começarmos com a organização da escola, limpeza, tudo ser colocado em ordem e isso sendo o início do projeto acho que daria certo, e a partir daí passar para o meio ambiente externo. Não adianta fazer horta lá fora e aqui dentro estar uma bagunça. Não adianta encher de flor um jardim lá fora, se aqui dentro o banheiro é sujo. Temos que começar pela conscientização dos alunos, eles saberem que a limpeza é importante, que a escola é como a casa deles, nós cansamos de falar isso". EE Alfa 5

"Na escola estão as futuras gerações e muitas vezes a criança ensina para os seus pais. Principalmente as crianças pequenas de $1^{\underline{a}}$ a $4^{a}$ série, o que a professora falou pra ela é lei - a minha professora falou (...)". EE Beta 3

\subsubsection{Agenda 21 como estratégia de ensino na escola}

Mesmo os professores que responderam conhecer a Agenda 21, ao serem questionados sobre a sua utilização enquanto estratégia de ensino na escola, não souberam emitir sua opinião. Após alguma discussão o grupo questionava quais seriam as estratégias que poderiam advir da Agenda 21, confirmando um despreparo nesse sentido além de falta de informação e compreensão sobre o assunto. Apenas dois professores estavam seguros e foram objetivos em suas respostas, inclusive exemplificando com o trabalho realizado a partir da proposta, como se percebe pelo relato a seguir: 


\begin{abstract}
"A Agenda 21 veio pra ajudar a ter uma maior conscientização de todas as disciplinas. Não que isso já não fosse solicitado, mas para um fechamento, e por ela ser global passa a ter uma força maior pra gente poder trabalhar (...) Por exemplo: a conservação do patrimônio - nós já trabalhamos com esse tema, mas após a reunião da Agenda 21 estruturou melhor porque há uma cobrança e uma participação maior. Os projetos sempre foram (uma forma de cobrança), mas a Agenda 21 avançou para que isso se tornasse real, saiu do papel e se tornou realidade". EE Gama 9
\end{abstract}

\title{
4.1.6 Material sobre a Agenda 21 na escola
}

Ao serem questionados sobre a existência de material didático sobre Agenda 21 na escola somente os professores de Ciências e Geografia, que participaram das reuniões de capacitação, e os seus coordenadores associaram a Agenda 21 à publicação da CENP "Água hoje e sempre: consumo sustentável". A maioria dos docentes desconhecia a publicação e/ou outros materiais didáticos que traziam informações sobre a Agenda 21.

“Não, se existe nós não conhecemos". EE Gama 7

"Recebemos os 10 livros da Diretoria de Ensino e foi distribuído para 1 representante de cada área. Apesar de ter participado da reunião na DE eu fui pesquisar e li a Agenda 21 do estado para poder realizar o trabalho. A Agenda 21 é muito mais ampla”. EE Gama 9

"Eu vi uma vez só um livro sobre a água, quando nós tínhamos que montar o projeto sobre a água”. EE Beta 6

"Na biblioteca de classe tem livros que falam sobre ecologia e deve ter informações sobre a Agenda 21". EE Pi 1

Para trabalhos e projetos com meio ambiente os professores indicaram ter utilizado livros didáticos, revistas, jornais, documentários e 
matérias jornalísticas veiculadas pela televisão, internet como fonte de informação, atualização e pesquisa.

Essas opiniões causam uma certa estranheza, já que todas as escolas estaduais possuem bibliotecas que, por meio do Programa Nacional do Livro Didático - PNLD, têm sido atualizadas constantemente e contam com publicações sobre meio ambiente e educação ambiental, que deveriam ser utilizadas como fonte de pesquisa pelos professores e alunos.

Um professor de Geografia ao referir-se aos livros didáticos salientou que os temas relacionados ao meio ambiente, normalmente, estão inseridos no final dos livros didáticos de maneira que correm o risco de não serem abordados quando o conteúdo programático não for esgotado no ano letivo. É preciso salientar que, na publicação oferecida para os professores, o capítulo referente a Agenda 21 Escolar também foi colocado no final, e mesmo entre os professores que haviam utilizado o material, não chegaram a ler este capítulo.

Em alguns casos os livros não foram distribuídos, ficando com o professor coordenador, ou ainda, foram distribuídos e não estão mais na escola devido à rotatividade dos professores.

"Existe, eu recebi 10 exemplares que foram destinados para cada escola, só que só sobraram dois, um no meu armário e outro no armário da professora de biologia, os outros eu não sei onde estão. Esse é o manual da água consumo sustentável?". EE Alfa 5

Isso não impediu os professores de trabalharem dentro da temática ambiental de forma transversal, e utilizarem fontes didáticas alternativas ao convencional livro didático e literatura.

Porém é fundamental o cuidado com as fontes de informação e a leitura dos fatos por meio da explicitação das ideologias que permeiam as questões ambientais. A falta de profundidade e a desvirtuação do foco central dos problemas ambientais, como reflexos de disparidades sócio- 
econômicas, tem banalizado questões muito sérias pelas mídias que atingem a grande massa.

Daí o papel fundamental do professor, como formador, de estar atualizado e ser um leitor crítico do tempo e espaço em que vive. Todo esforço nesse sentido deve ser bem aproveitado. No caso do livro "Água hoje e sempre: consumo sustentável", que prioriza os recursos hídricos para tratar a questão da sustentabilidade, as escolas que o utilizaram como metodologia de trabalho tiveram um ganho em qualidade muito grande porém, por diversos fatores a maioria não o utilizou, perdendo-se um trabalho de reorientação do ensino no sentido do desenvolvimento sustentável, conforme orienta a Agenda 21 Global.

\subsubsection{Cursos de capacitação para professores}

Os cursos de capacitação, realizados pela Oficina Pedagógica têm como objetivo "desenvolver, dentro de sua área específica de atuação, ações descentralizadas de formação continuada" (Artigo 4ํ- parágrafo IV CENP) e "desenvolver ações a partir de demandas específicas das escolas e ou propostas pelos órgãos centrais" (Artigo 4ํ- parágrafo X - CENP).

O desenvolvimento de cursos para os professores a partir da área específica de atuação, pressupõe como sugerem os PCNs, que o professor detenha habilidades e competências para reconstruir saberes de forma interdisciplinar, transdisciplinar na sua prática pedagógica.

Os cursos de licenciatura não seguem essa orientação; as capacitações também não, logo, resta ao professor procurar caminhos empiricamente e dispor de competência técnica e habilidade relacional para conseguir elaborar ações em conjunto com seus pares.

Dos professores participantes desses encontros espera-se que levem as experiências vivenciadas para a escola a que pertencem. Para que isso aconteça, primeiramente, o HTPC precisa configurar-se em espaço de socialização de experiências, adequando-se ao seu objetivo. Segundo os 
professores, esse espaço coletivo é desperdiçado exclusivamente com informes de ordem administrativa e pedagógica, porém, não se configura em espaços de discussão e construção de conhecimento.

Os resultados são opostos onde essa prática é diferente, ou seja, onde os professores são estimulados a usar as reuniões do HTPC para conversar, trazer experiências pedagógicas, trocar informações e trabalhar em projetos coletivos, sejam eles interdisciplinares ou multidisciplinares, ao longo do ano.

Uma experiência que mostrou-se positiva foi a de cursos que aconteceram de forma descentralizada nas escolas com toda a equipe docente e gestora conjuntamente. Esses cursos foram desenvolvidos em escolas que tiveram baixo desempenho no SARESP, como uma tentativa de buscar soluções com a equipe escolar. Desses encontros surgiram propostas contextualizadas à realidade da escola que, segundo os professores, foram os melhores cursos que já participaram.

\subsection{AS ESCOLAS DE LOUVEIRA}

A experiência da cidade de Louveira foi escolhida por ter apresentado resultados significativos com relação a amplitude do trabalho sobre a Agenda 21.

Quatro escolas deste município pertencem à Diretoria de Ensino de Jundiaí. Dessas 4 Unidades Escolares (UE), 3 contavam por ocasião da pesquisa, com um quadro de 90 a $100 \%$ de docentes efetivos (dados de 2005 e projeção para 2006), consolidando-se a perspectiva de continuidade de trabalho e efetivando-se a integração dos professores com a escola e o amadurecimento das relações inter-pessoais e do processo educativo.

No início do ano de 2005, a Divisão de Meio Ambiente (DMA) do Município propôs à Secretaria de Educação (SE) Municipal a realização de 
um projeto conjunto para a construção da Agenda 21 Escolar, objetivando a formação de fóruns de discussão e de educação ambiental.

Segundo o Diretor da DMA, Sr. Luis Rosa idealizador dessas iniciativas, a necessidade de propor medidas que pudessem suscitar mudança de valores com relação ao meio ambiente tem guiado suas ações no sentido de incluir a promoção da educação ambiental e a formação da cidadania crítica e responsável entre os temas a serem trabalhados com as unidades escolares. A partir do engajamento da comunidade escolar esperava-se que, num segundo momento, essa participação se efetivasse na construção da Agenda 21 do Município no ano de 2006, e na integração de diretrizes sustentáveis para o Plano Diretor Municipal.

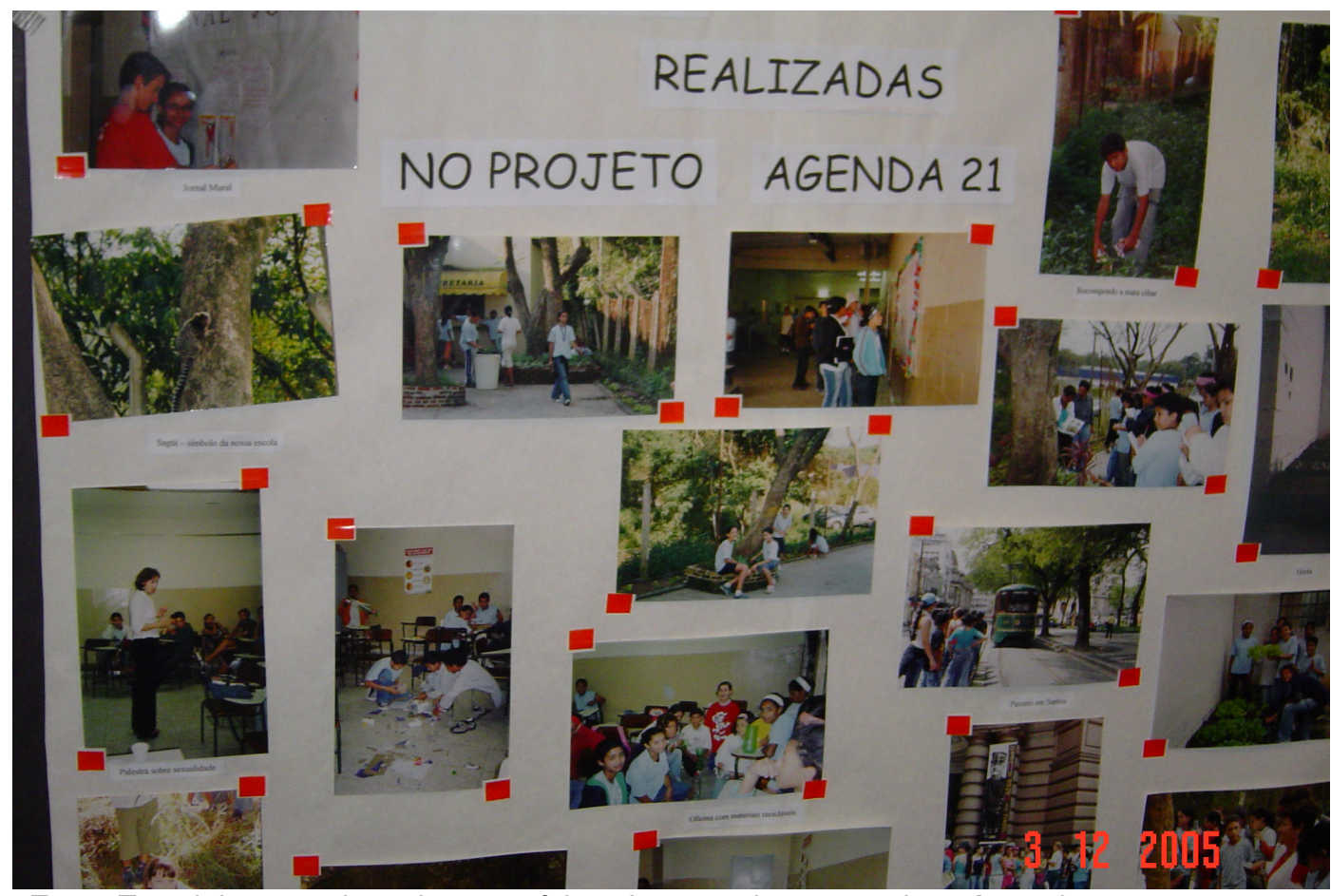

Foto: Envolvimento de todas as séries das escolas no projeto Agenda 21.

O trabalho da administração municipal expandiu-se para a Diretoria Regional de Ensino DE Jundiaí com o intuito de abranger as escolas estaduais, além de diversos grupos da sociedade civil como comunidades religiosas, escoteiros, grupos de meninas, a fim de realizar um trabalho de educação ambiental para pessoas de variados segmentos. 
O principal foco dos trabalhos foi a água, em função da localização estratégica da cidade na Unidade de Gerenciamento de Recursos Hídricos UGRH 5, Bacias Hidrográficas dos Rios Piracicaba, Capivari e Jundiaí. Que encontra-se em situação crítica de impacto ambiental.

Todas as escolas de Louveira recebem apoio financeiro da prefeitura na forma de verba de subvenção mensal para gastos com material didáticopedagógico e outros que cada unidade teve autonomia para a utilização. $\mathrm{O}$ valor dessa verba gira em torno de hum mil reais por escola, que corresponde a US\$300 na cotação de novembro/2005, o que segundo os gestores, é suficiente para cobrir as necessidades que outras verbas não cobrem, muitas vezes por terem destino específico.

Para o ano de 2005, a Prefeitura disponibilizou apoio técnico e operacional para as escolas poderem desenvolver o trabalho da Agenda 21 Escolar, o que efetivou-se por meio de reuniões, veículos para saídas de campo, logística para realização de eventos, equipamentos e material didático.

Foram organizadas reuniões com os gestores e os professores de Ciências e Biologia de todas as escolas localizadas no município. A partir da apresentação da proposta para o grupo, o processo foi conduzido de forma participativa e com os temas de cada encontro pautado segundo a demanda das escolas. Iniciou-se o trabalho com o estudo de documentos como a Agenda 21 Global (1992), o Tratado de Educação Ambiental para Sociedades Sustentáveis e Responsabilidade Global (1992), pelo Programa Nacional de Educação Ambiental produzido pelos MMA, MEC, MCT, MEC, entre outros.

Aconteceram estudos de campo conduzidos por técnicos da DMA com os professores para que esses conhecessem o espaço e a realidade do entorno das escolas e das áreas de manancial do município. 
Como conclusão dos trabalhos realizados em 2005 foi organizada uma mostra no Centro de Lazer de Louveira, um espaço de exposições da cidade, o 1 EMESA (Encontro Municipal de Educação e Sustentabilidade Ambiental) onde cada escola apresentou os projetos desenvolvidos durante o ano e as propostas para a construção da Agenda 21 de Louveira. Esse evento, que aconteceu no dia 3/12/2005, teve a presença de 2000 pessoas entre alunos, professores e pais (DMA - Louveira), o que mostra o envolvimento da comunidade e garantiu o compromisso de continuidade do processo, em 2006.

Segundo o Diretor da DMA pretende-se a ampliação das ações de formação em educação ambiental para o empresariado da cidade, a partir de 2006, como forma de ampliação do processo e envolvimento de outros segmentos da sociedade. A atuação do poder público por meio da DMA de Louveira, coordenando ações educativas diferenciadas e condizentes com as propostas da Agenda 21 Global, com objetivo de construção da Agenda 21 local, mostrou, segundo os professores, uma inovação e mudança de postura dentro da administração pública, o que poderá significar o início de um processo de "empowerment" por parte dos docentes e agentes envolvidos.

A seguir apresentam-se os dados coletados nas escolas do município de Louveira, utilizando-se a mesma categorização já utilizada para as escolas de Jundiaí. 


\subsubsection{O trabalho com projetos}

O principal projeto do ano de 2005 , realizado nas escolas de Louveira foi o da Agenda 21 Escolar que priorizou a questão hídrica do município, e permeou todos os demais existentes nas escolas. Esse projeto, apesar de não ter sido realizado por todas as séries e por todos os professores, foi planejado conjuntamente e teve seus resultados socializados na escola e num segundo momento, na exposição do $1^{\circ}$ EMESA .

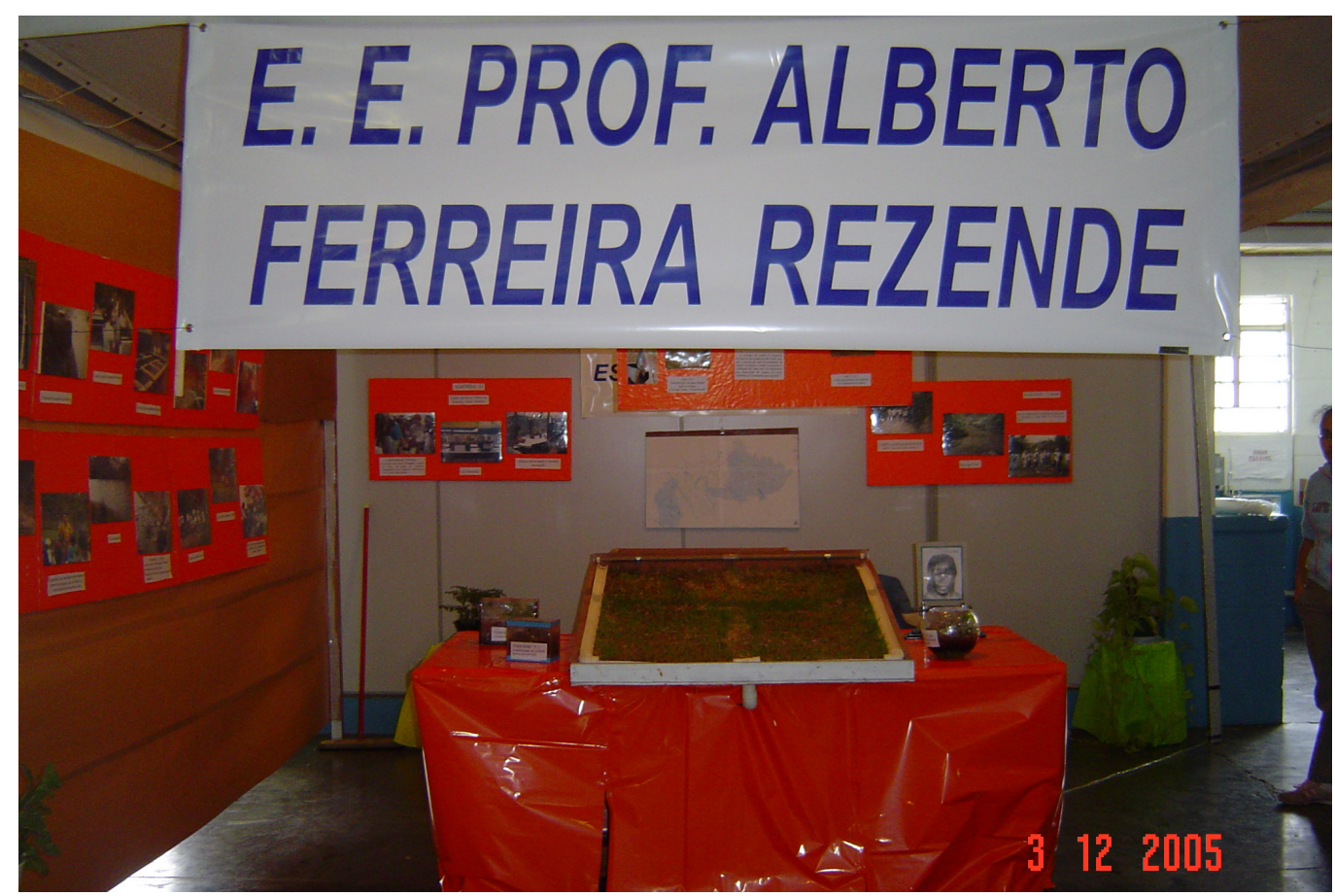

Foto: Proposta de Estação de Tratamento de esgoto com disposição superficial do esgoto. EE Prof. Alberto Ferreira Rezende.

Outros projetos desenvolvidos relacionam-se com a implantação de hortas nas escolas, coleta seletiva de lixo e leitura .

Os projetos foram definidos no planejamento do início do ano, e também seguem temas propostos pela Diretoria de Ensino de Jundiaí, Secretaria Municipal de Educação, e outros são definidos dentro da escola. 


\subsubsection{Projetos sobre meio ambiente}

É importante relatar a qualidade ambiental das escolas visitadas quanto à preservação do patrimônio e a condição de bem estar presente nos espaços escolares da cidade. Primeiramente, com relação à limpeza: todas as unidades são extremamente limpas, bem cuidadas e sem pixações, apesar de duas das escolas não terem estrutura ideal para funcionamento. Uma delas funciona em um prédio provisório construído com estrutura prémoldada e com número reduzido de salas, o que não comporta biblioteca e sala para reuniões. A outra escola localizada na área rural, tem seu prédio construído a 5 metros do Rio Capivari, o que a torna vulnerável às enchentes e ao mau cheiro em alguns períodos.

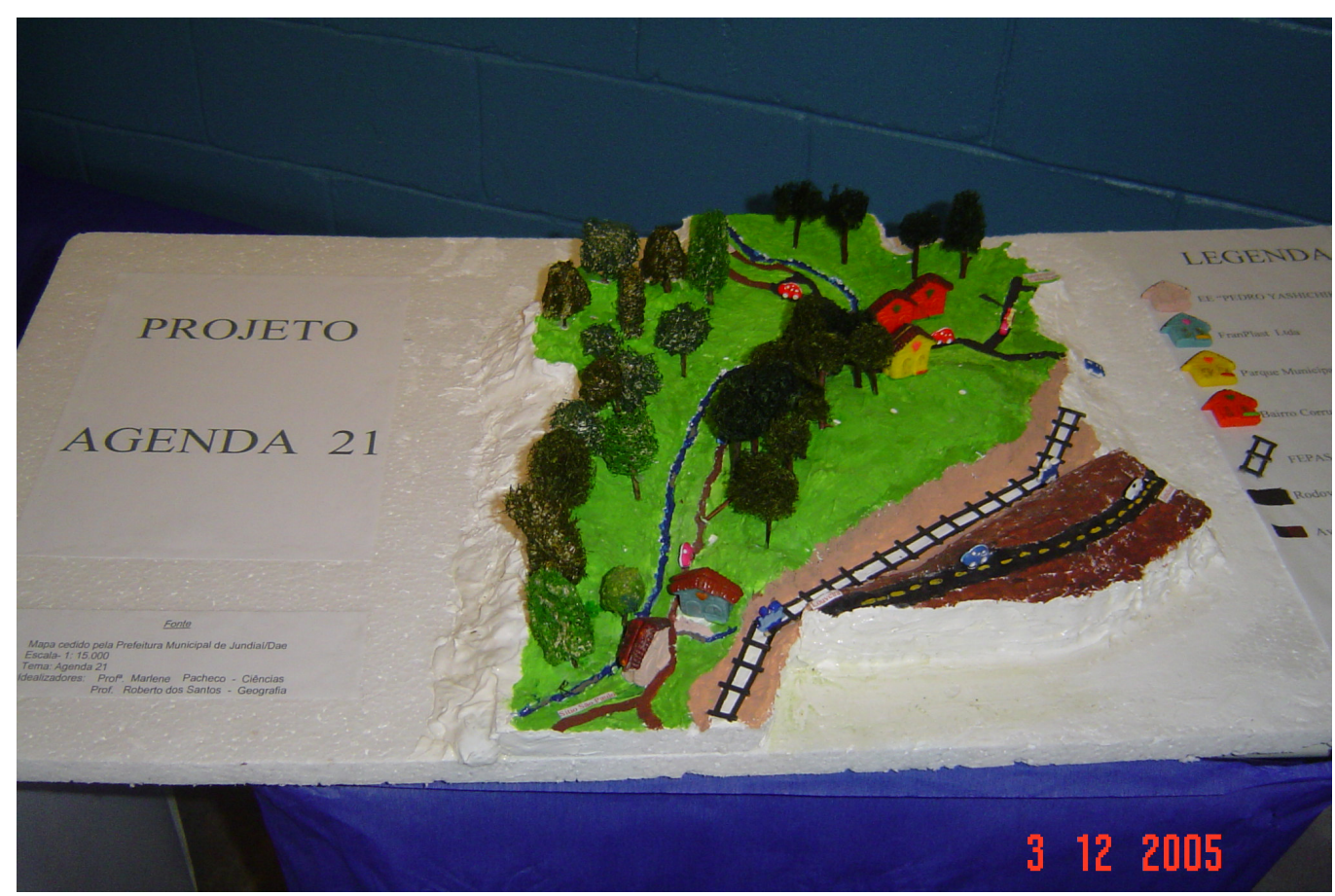

Foto: Construção de Maquete da área da escola para estudo do Rio Capivari. EE. Pedro Yoshichika Irie.

O cuidado com a organização das escolas e com o patrimônio é visível e tomado como responsabilidade de todo o grupo docente. Apesar do projeto da Agenda 21 Escolar também ser coordenado e executado prioritariamente pelos professores de Ciências, Biologia e Geografia, os 
professores de todas as disciplinas se sentiam responsáveis e salientavam a sua participação diária na conquista de um "ambiente escolar mais saudável".

O ambiente escolar foi considerado como ponto de partida para as discussões e mudança de atitudes com relação ao meio ambiente. Para exemplificar, os professores da escola Ômega 1 citaram como projeto relacionado a meio ambiente o Projeto "Fala mansa" que consiste na instalação de um semáforo dentro das salas a fim de controlar o ruído, com intervenção dos alunos e professores. Dessa forma, aconteceu a diminuição do barulho na escola e o respeito aos limites estipulados pelo grupo visando o bem estar de todos.

\section{Água}

A água foi tratada com destaque nos projetos de todas as escolas, por ser definida como prioridade de ação para o município.

Foto: Maquete de Estação de tratamento de água. EE Odilon Leite Ferraz.

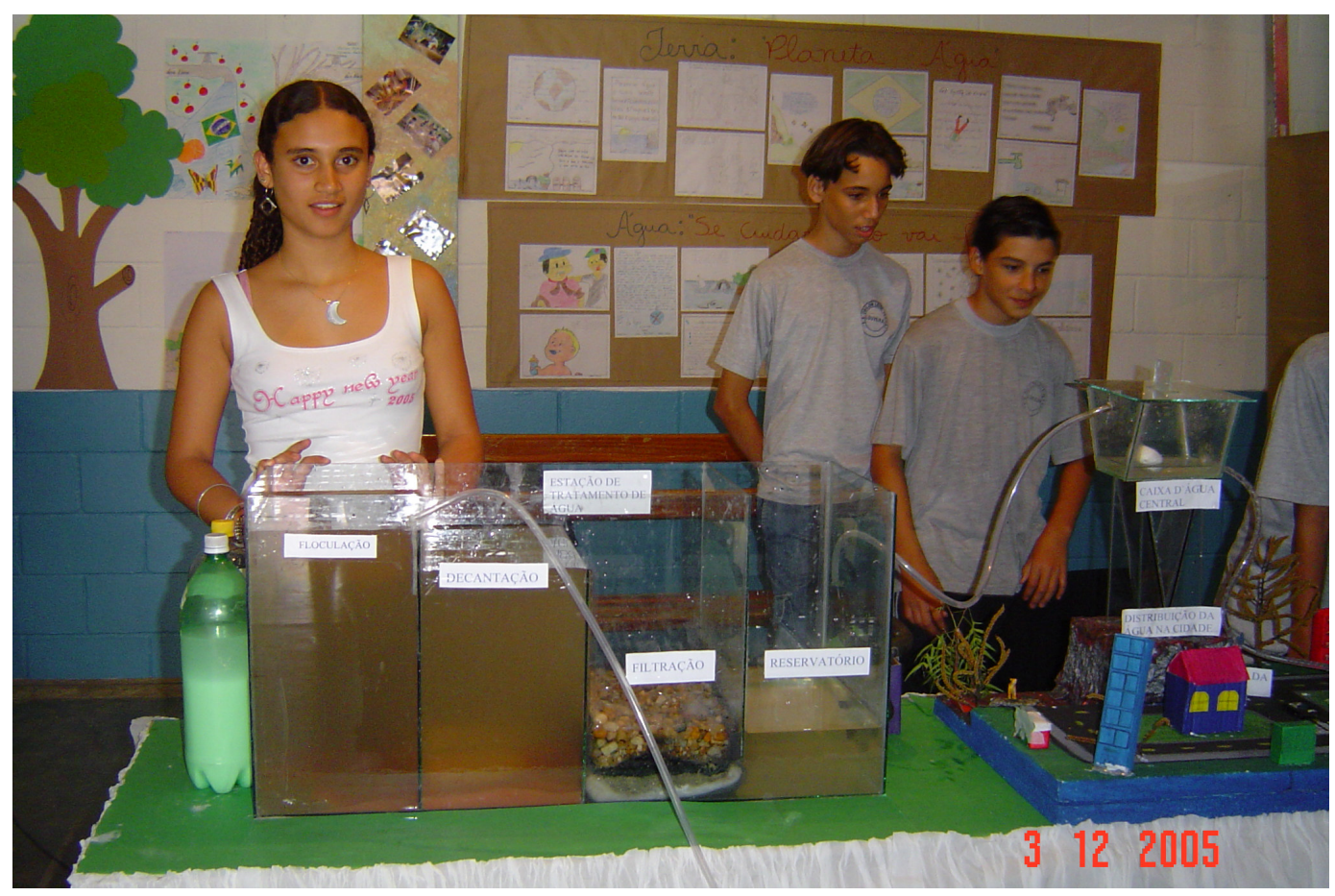


Os projetos sobre a água deram ênfase à conservação dos recursos hídricos.

A professora responsável pelo trabalho na escola Ômega 3 realizou o projeto da Agenda 21 Escolar a partir do tema água com as turmas da $7^{\underline{a}}$ série e indicou a continuidade do trabalho de educação ambiental, iniciado com as mesmas turmas desde a $5^{\mathrm{a}}$ série como um dos pontos positivos para o sucesso e participação efetiva dos alunos no processo.

Segundo ela, o trabalho nesses três anos de Ensino Fundamental desenvolveu habilidades e competências nos alunos, de tal forma que os temas trabalhados para o projeto da Agenda 21 Escolar foram desenvolvidos com desenvoltura uma vez que tinham domínio de conhecimentos, linguagem e valores adquiridos anteriormente.

Nessa escola, como em todas as outras de Ensino Fundamental II do município, os alunos visitaram as áreas de mananciais da cidade e pesquisaram os rios próximos às escolas. A partir do diagnóstico da questão hídrica do bairro e do município montaram maquetes de estação de tratamento de água e esgoto com o objetivo de orientar a comunidade quanto à importância do tratamento da água e do esgoto para a cidade e região. Todas as escolas propuseram a construção da estação de tratamento de esgoto na cidade como uma prioridade para a qualidade das águas da cidade para as futuras gerações, alinhando-se as propostas da Agenda 21 Escolar às da Agenda 21 Global.

Em julho de 2006 o Diretor da SMA informou que a construção da Estação de Tratamento de Esgoto já estava em curso, atendendo à determinação do Ministério Público e às reivindicações da população demonstradas, entre outros momentos, no $1^{\circ}$ Encontro Municipal de Educação e Sustentabilidade Ambiental 


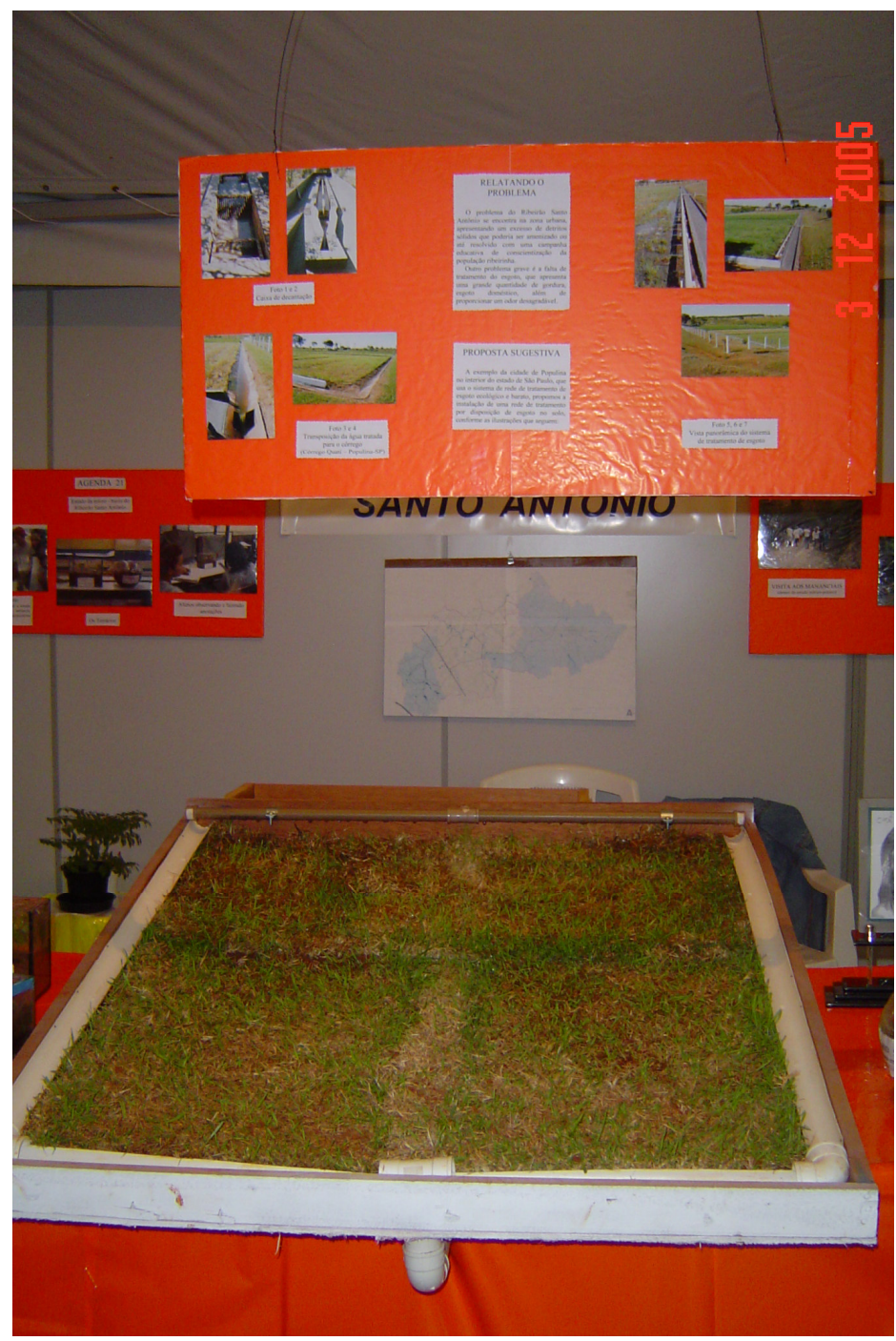

Foto: Proposta de Estação de tratamento de Esgoto.

\section{$\underline{\text { Resíduos Sólidos }}$}

Todas as escolas participaram do projeto de coleta seletiva da prefeitura Municipal desenvolvendo anualmente um trabalho pedagógico que prioriza a orientação quanto à necessidade de redução da quantidade de resíduos sólidos e separação de lixo seco e orgânico, com instalação de coletores separados.

Na presente gestão, a Prefeitura transferiu o trabalho da coleta de lixo reciclável para o município, tendo como objetivos: a redução da quantidade de descarte de resíduos sólidos, a reciclagem de materiais e a reintegração 
de cidadãos ao trabalho. Foi construído um centro de triagem de resíduos onde os trabalhadores cooperativados trabalham em sistema de rodízio, recebem treinamento e participam e cursos diversificados de formação profissional.

A renda proveniente da venda do material é destinada à Santa Casa da Cidade ( $80 \%$ ) e à Clínica Interdisciplinar de Educação Ambiental de Louveira - CIELO (20\%), entidade que atende crianças portadores de necessidades especiais. Em 2005, o valor arrecadado foi sessenta e oito mil reais, que corresponde a cerca de US\$30.000,00 pela cotação de julho de 2006, contribuindo significativamente para o desenvolvimento das atividades de ambas as entidades.

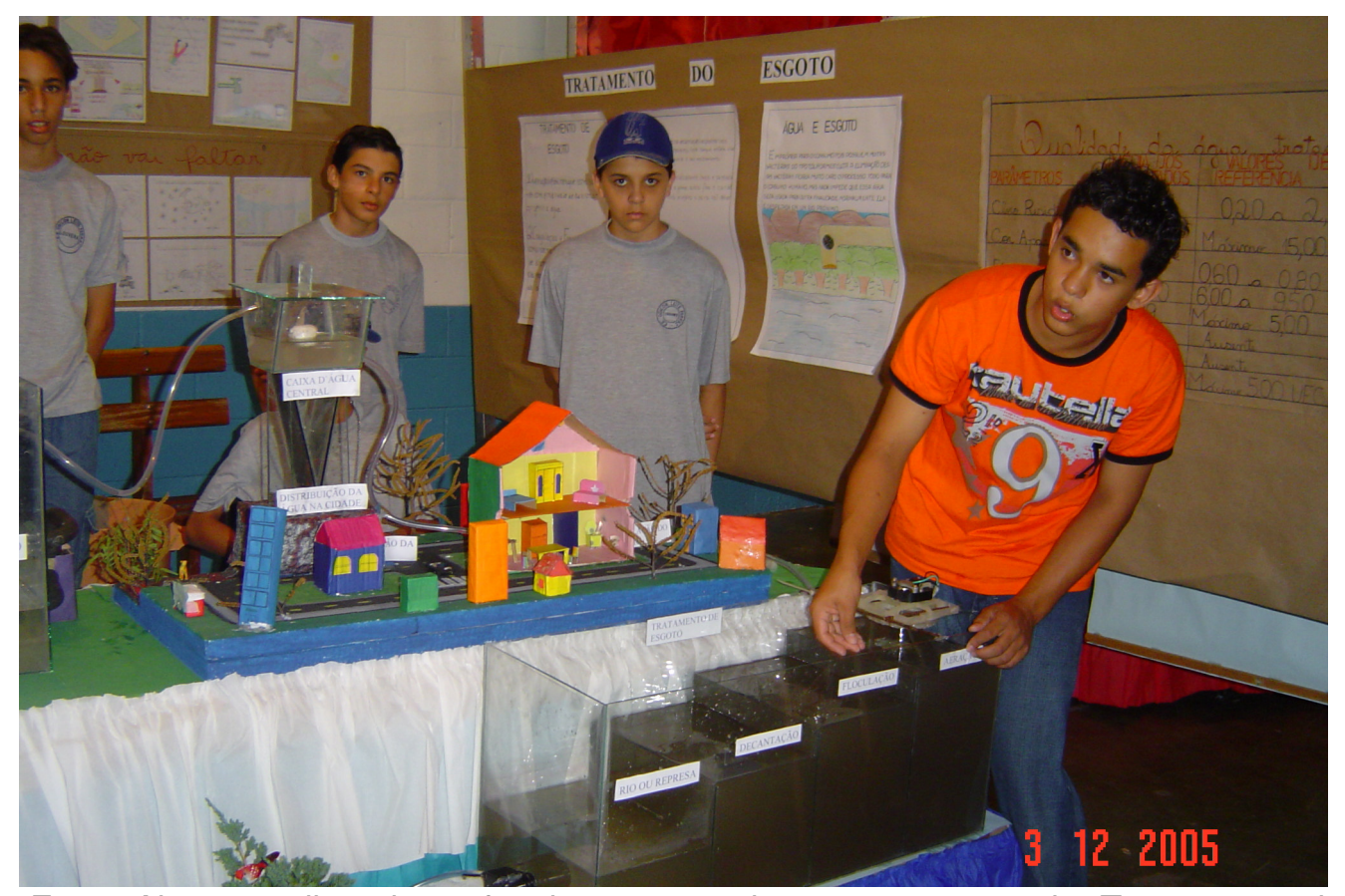

Foto: Aluno explicando o funcionamento de uma estação de Tratamento de Esgoto. EE Odilon Leite Ferraz

4.2.2 Capacidade de desenvolver temas relacionados ao meio ambiente

Uma das gestoras relatou a experiência que antecede à realização de qualquer projeto na escola, exemplificando com o Projeto da Agenda 21 e 
outros sobre meio ambiente, com relação à troca de informações e o processo de construção interdisciplinar na escola.

A primeira coisa que se faz são oficinas. Os professores fazem com os colegas o que eles fariam em sala de aula. Discutem...se algum tem uma perspectiva diferente os professores fazem intervenções, enriquecendo o trabalho antes de ir para sala de aula. EE Ômega 3

\subsubsection{Representação sobre a Agenda 21}

Vários professores relacionam a Agenda 21 com preservação ambiental, entendendo meio ambiente a sala de aula, a escola, o bairro, a natureza, os mananciais.

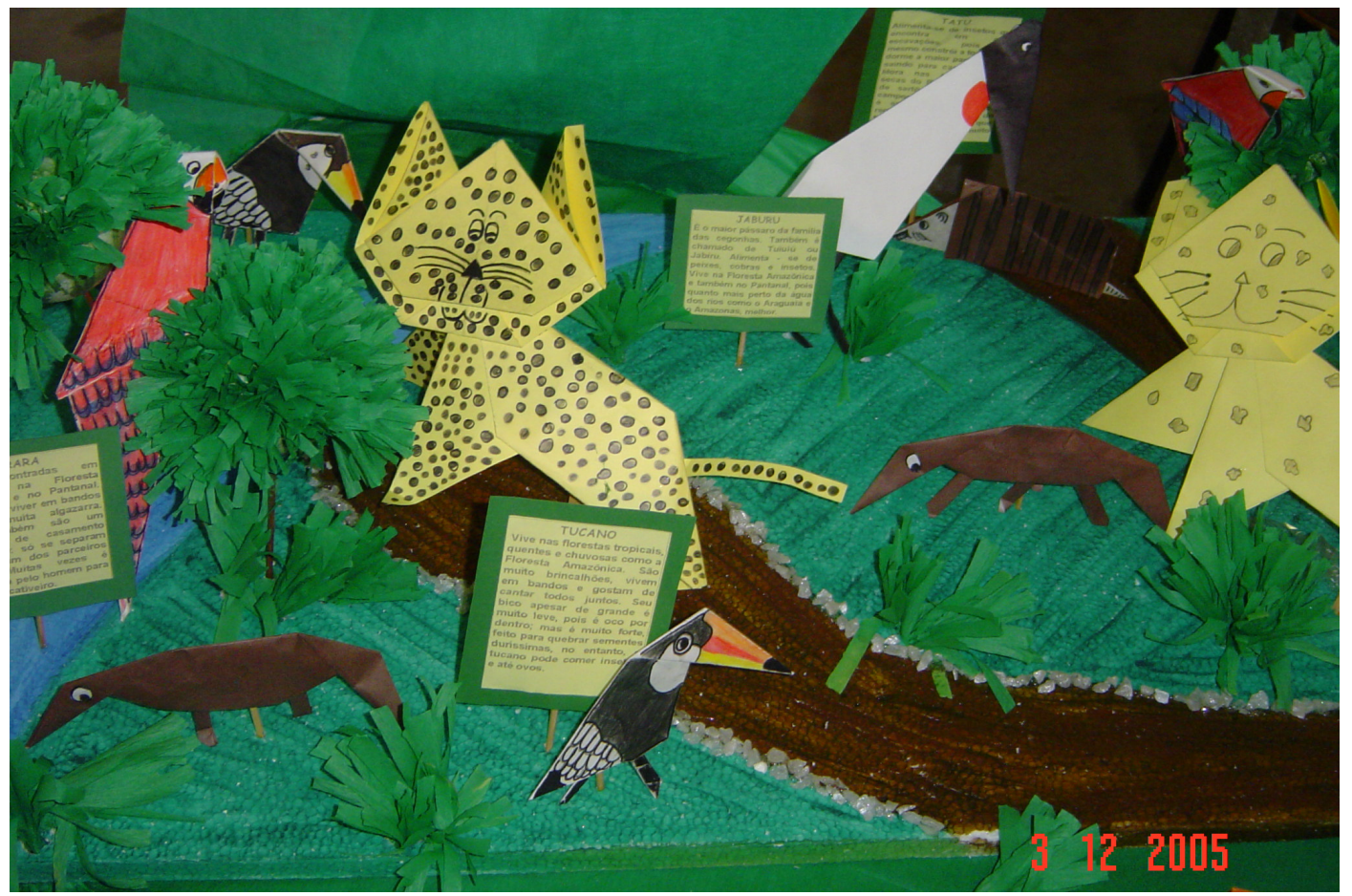

Foto: Representação de preservação ambiental expressa pelos alunos por orientação dos professores. 
Outros, têm a representação de que a Agenda 21 é uma formalização de propostas que já fazem parte do seu cotidiano, como formação para a cidadania e busca de melhoria na qualidade de vida.

(...) começa tem que dar continuidade e ir conscientizando (...) o que nós (na escola) poderíamos estar fazendo por nós e para o futuro.EE ômega 2

\subsubsection{A escola como um local para a implantação da Agenda 21}

Os professores consideram o papel da escola um importante espaço de formação, e que a proposta da Agenda 21 é mais uma opção que pode colaborar com o processo educativo.

A escola é um dos locais mas não deveria ser o único (...)

o mesmo que foi feito aqui deveria ser feito em comunidades de bairro, igreja(...). EE Ômega 1

Uma das escolas considerou a questão da continuidade do trabalho para os próximos anos, como positiva por estabelecer um fio condutor com relação à busca de integrar os alunos aos problemas do bairro e do município.

Numa outra situação a professora indicou a condição particular de gestão democrática e participativa da escola facilitadora para a construção da Agenda 21.

A escola se mostra empenhada e tem um grupo de professores bem interessados, porque nos vivenciamos, (uma gestão) com direção e coordenação ativos, empenhado e participativos. Isso é importante. As pessoas aqui sempre deram liberdade (...). EE Ômega 3 


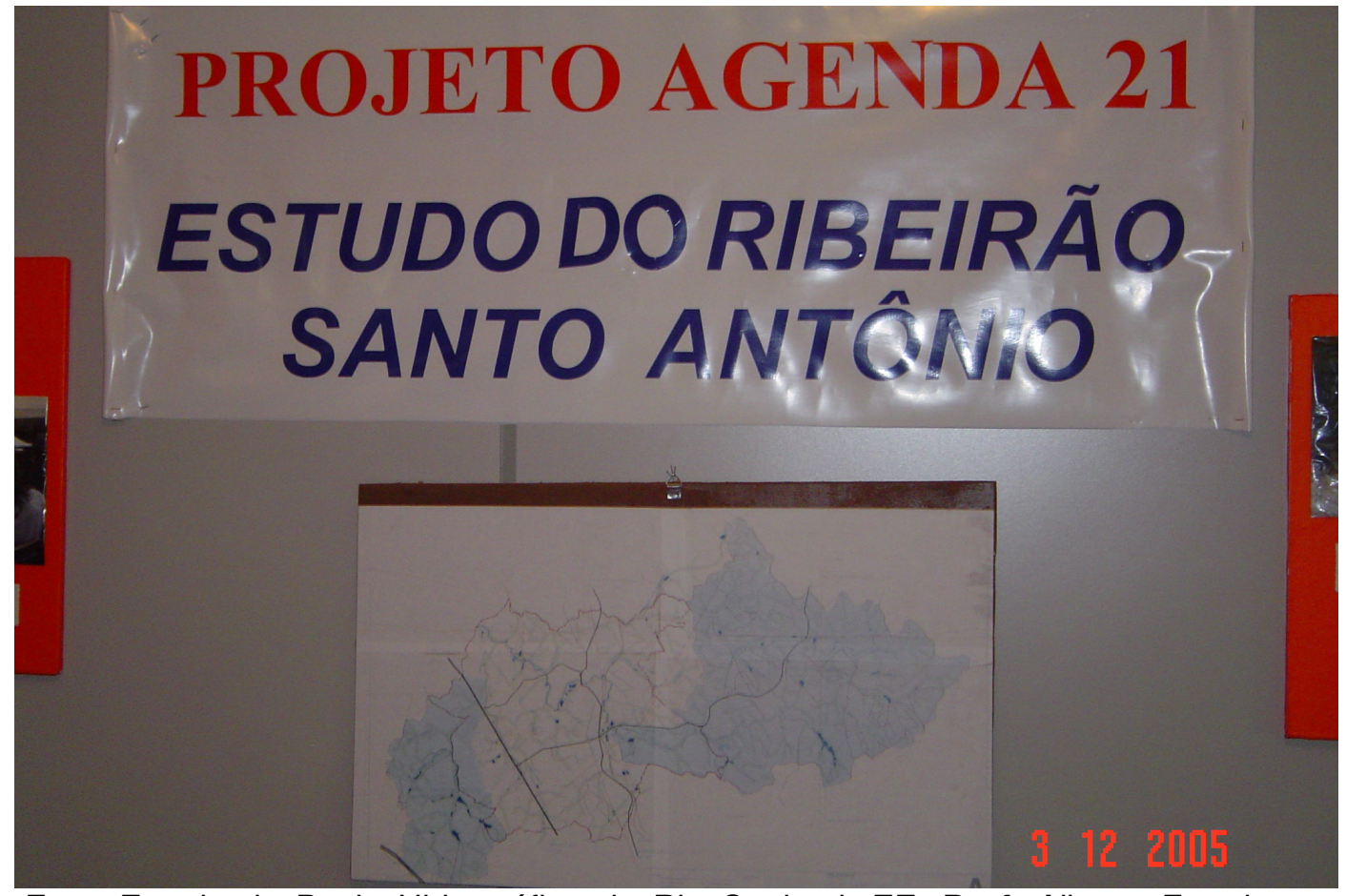

Foto: Estudo da Bacia Hidrográfica do Rio Capivari. EE Prof. Alberto Ferreira Rezende

\subsubsection{Agenda 21 como estratégia de ensino na escola}

As estratégias utilizadas para a construção da Agenda 21 foram consideradas muito válidas, pois levaram os alunos a refletirem sobre a sua realidade, conseguindo unir $o$ desenvolvimento de habilidades e competências ao início de um processo de mudanças de valores com relação ao meio ambiente. A seguir, o depoimento de um dos professores que orientou o trabalho com alunos da $7^{\underline{a}}$ série.

É válido pois os alunos acabaram pensando em coisas que normalmente eles não pensariam, e o resultado acaba sendo um resultado reflexivo, como saber que existem casas que não têm água encanada, ruas que não são asfaltadas, que existem lugares onde não se recolhe o lixo (...). EE Ômega 3 


\subsubsection{Material sobre a Agenda 21 na escola}

O material sobre a Agenda 21 também é escasso nas escolas de Louveira, restringindo-se ao livro "Água hoje e sempre: consumo sustentável" e outros disponibilizados pela Divisão do Meio Ambiente nas reuniões para a realização o desenvolvimento do projeto em parceria, o que, segundo os professores, fez diferença no resultado alcançado.

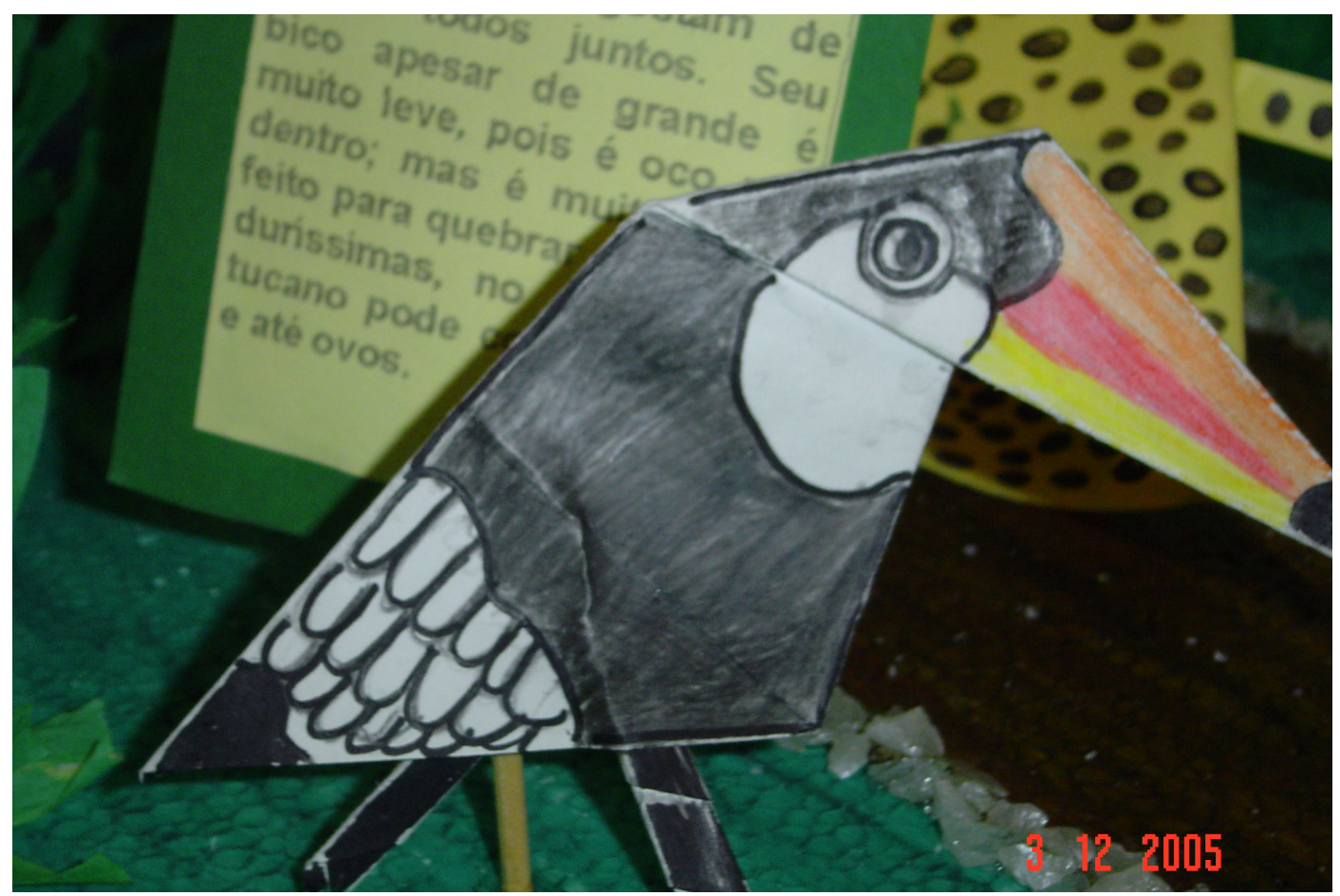

Foto: Os professores têm adaptado alguns materiais para o desenvolvimento de suas temáticas com extrema criatividade.

\subsubsection{Cursos de capacitação para professores}

Nas escolas de Louveira, fazia parte da rotina dos docentes que participaram das atividades de capacitação socializar com os demais colegas o que aprendeu. Isso deve ser uma prioridade para o corpo gestor dessas unidades. Essa prática incorporada à atividade pedagógica, não só viabiliza a socialização, mas transforma-se num exercício de reconstrução de saberes, numa prática interdisciplinar. Os professores relataram que 
muitas vezes os projetos propostos pela Diretoria de Ensino foram mudados e adaptados à realidade das escolas, como aconteceu com a proposta do projeto sobre a Água e Agenda Ambiental. 


\section{CONCLUSÕES}

O conhecimento dos professores sobre as questões ambientais, de uma forma geral, limita-se ao senso comum e resulta de informações obtidas nas mídias televisiva e jornalística, carecendo de profundidade e precisão. A representação de meio ambiente entre os professores ainda é naturalista e intimamente relacionada aos aspectos físicos e biológicos do mesmo.

Os professores de ciências, biologia e geografia sentem-se mais preparados para tratar de temas ambientais pela formação específica que tiveram e por serem constantemente convocados a participar de cursos de capacitação oferecidos pela SEE sobre temas ambientais. Situação bem diferente acontece com os professores das demais disciplinas que se sentem despreparados e sem fundamentação para tratar de questões ambientais.

Os temas relacionados ao meio ambiente não têm sido tratados de forma interdisciplinar nas escolas. A interdisciplinaridade proposta pelos projetos precisa ser incorporada por todos os professores que ainda mantêm um tratamento apenas disciplinar aos temas, no caso da água e sua situação emergencial por exemplo, a dificuldade de entrosamento e interpenetração das diversas disciplinas foi uma barreira para a concretização de propostas que visavam a sustentabilidade no contexto vivenciado pelo aluno.

As estratégias utilizadas pelos professores precisam se basear em metodologias mais modernas e que venham ao encontro de necessidades sentidas pelos alunos.

A maioria das práticas pedagógicas pretenderam sensibilizar e orientar mudanças comportamentais no cotidiano, o que é positivo e 
necessário, porém ainda estão distantes da educação enquanto prática política que transforma a sociedade.

As escolas que utilizaram a metodologia proposta do livro "Água hoje e sempre: consumo sustentável" apresentaram realmente um ganho qualitativo no trabalho, ampliando sua perspectiva de meio ambiente, ainda que os trabalhos tenham sido tratados sob uma abordagem disciplinar.

Os projetos e trabalhos apresentados sobre meio ambiente deram destaque especial ao tema água demonstrando que as escolas estaduais acataram as sugestões propostas pelo órgão gestor representado pela CENP - SEE.

Foram poucos os docentes que ampliaram a sua representação de meio ambiente incluindo o ambiente vivenciado e contextualizado sóciohistórico e economicamente. Dessa forma, a educação ambiental não se tornou efetiva na prática pedagógica das escolas, pois o trabalho se restringiu a um grupo de professores e com trabalhos bastante pontuais.

A representação social dos docentes sobre a Agenda 21 está relacionada à preservação e conservação da natureza, à qualidade de vida $\mathrm{e}$ à água. A relação majoritária foi com o tema água em função da divulgação do projeto Agenda 21 Escolar ter sido vinculado à divulgação do livro "Água hoje e sempre: consumo sustentável".

Os docentes desconhecem as Agendas Global, Nacional, Estadual, ou alguma das Agendas Locais já implantadas no Brasil e nem relacionam a Agenda 21 Escolar à gestão sustentável da escola, e às inúmeras possibilidades dela decorrentes.

Algumas escolas de Jundiaí iniciaram o processo de estudo da Agenda 21 e, segundo os professores coordenadores, deverão dar continuidade aos trabalhos em 2006. 
Poucas escolas de Jundiaí tiveram resultados concretos de ação transformadora de realidade.

Nas escolas de Louveira os trabalhos apresentaram a compreensão da Agenda 21 como um processo gestor e relacionaram a prática pedagógica ao cotidiano escolar, pesquisando, analisando, produzindo conhecimento e interagindo com o poder público, ou seja, exercitando a prática da cidadania e tendo como preocupação principal a sustentabilidade, a partir do tema água.

O apoio recebido do poder municipal, por meio da Divisão do Meio Ambiente e Secretaria da Educação, foi decisivo para o sucesso dos resultados de construção da Agenda 21 Escolar.

O caso de Louveira demonstrou os resultados positivos desse percurso no desencadeamento do processo de construção da Agenda 21 Local. É evidente que há um caminho muito longo e árduo no sentido de efetivação dessa prática democrática, e da conquista da educação de qualidade para a grande massa que, por enquanto, representa apenas a melhoria quantitativa da educação no país

Apresentou-se como diretamente proporcional a relação entre as escolas que tem quadros mais estáveis de professores e gestores e as que conseguem elaborar propostas pedagógicas baseadas em projetos, ou seja, que pressupõem a educação como processo e trabalho de equipe.

A existência de condições objetivas de trabalho na educação, é resultado de vários fatores: estrutura física, material didático e, principalmente, funcionários em número e com qualificação adequada, assim como gestores e quadro docente estável e continuamente em processo de capacitação voltada para novas tecnologias educacionais e para melhoria da escola pública 
A proposta da Secretaria da Educação do Estado de São Paulo (SEESP) foi positiva por lançar a idéia da construção da Agenda 21 Escolar iniciando pela questão da água, porém, o processo precisa ser alimentado continuamente para não perder a sua essência e cair no esquecimento.

Como profissional da educação e estudiosa dessa realidade continuo a acreditar na sua ação transformadora. É preciso dar condições objetivas para que todos os educadores mantenham-se convictos da possibilidade de realizar uma prática educativa crítica, política e transformadora, como instrumento de recriação da realidade e de um sociedade justa e humanizada. 


\section{RECOMENDAÇÕES E SUGESTÕES}

Em função do estudo realizado sugere-se que:

Se incorporado à escola como mais um projeto, a Agenda 21 não seja tratada sem a importância de política pública que deveria assumir.

Enquanto política pública este processo deve estar envolvido com outros setores da administração pública e da sociedade.

O trabalho de capacitação seja realizado em todos os níveis da docência, de forma contínua e com qualidade.

As capacitações sobre meio ambiente e educação ambiental atendam aos docentes de todas as disciplinas, e não apenas ciências, biologia e geografia, a fim de ampliar a possibilidade de interdisciplinaridade.

Os cursos de licenciatura incorporem práticas interdisciplinares na formação dos futuros docentes, a fim de prepará-los adequadamente para uma nova visão de mundo, integralista, ampla e possibilitem ao aprendiz compreender o mundo e tornar-se um agente da sua história.

As escolas garantam o espaço dos HTPCs para a troca de experiências e construção coletiva, sem reduzir seu tempo com formalidades burocráticas.

Devem ser estimulados e organizados Fóruns no âmbito municipal ou das Diretorias Regionais de Ensino para a troca de experiências entre as escolas, e visibilidade de projetos com diferentes metodologias e abordagens.

As Agendas 21 Escolares devem ser estimuladas e implementadas nas escolas atendendo às necessidades de cada realidade. 


\section{REFERÊNCIAS}

Ab'Saber A. Reflexões sobre a educação ambiental; 1991. (Mimeografado).

Ab'Saber A. A Universidade brasileira na (re)conceituação da educação ambiental. Educação Brasileira, v.15, n. 31, p.107-115; 1993.

Alves N. e Garcia RL. A construção do conhecimento e o currículo dos cursos de formação de professores na vivência de um processo. In: ALVES N. (org.). Formação de Professores: pensar e fazer. São Paulo: Cortez; 2004.

Barbieri JC. Desenvolvimento e meio ambiente: as estratégias de mudanças da Agenda 21. $3^{\underline{a}}$ ed. Petrópolis:Vozes; 2000.

Bonotto DMB. A temática ambiental e a escola pública de ensino médio: conhecendo e apreciando a natureza. Dissertação de mestrado, Rio Claro SP; 1999, Centro de Estudos Ambientais da UNESP - Universidade Estadual Paulista.

Born R. Caminhos, descaminhos e desafios da Agenda 21 brasileira. Deb. Socamb. 1988/1999; 4(11):9-11.

Brasil. Lei Federal 9795, de 25 de abril de 1999. Política Nacional de Educação Ambiental. Diário oficial, 1999; (79): Brasília - DF.

Cascino F. Educação Ambiental: princípios, história, formação de professores. São Paulo: Editora SENAC São Paulo; 1999.

SE/CENP. Proposta Curricular para o ensino de ciências e programas de saúde: 1o grau. São Paulo: SE/CENP; 1988a. 
SE/CENP. Proposta Curricular para o ensino de geografia: 1ำ grau. São Paulo: SE/CENP; 1988b.

CNUMAD - Conferência das Nações Unidas sobre Meio Ambiente e Desenvolvimento. $2^{\underline{a}}$ ed. Brasília: Senado Federal, Subsecretaria de Edições Técnicas; 1997.

Coimbra JAA. O outro lado do meio ambiente. São Paulo, CETESB, 1985.

Comissão Pró Agenda 21 Rio. 21 Perguntas e respostas para você saber mais sobre a Agenda XXI Local. Rio de Janeiro s/d.

[CPDS] Comissão de Políticas de Desenvolvimento Sustentável e da Agenda 21 Nacional. Agenda 21 brasileira [CD ROM]. Brasília (DF); 2002.

Dias GF. Educação Ambiental: Princípios e Práticas. $5^{\circ}$ ed. São Paulo: Gaia; 1998.

Freire P. Educação como Prática da Liberdade. Rio de Janeiro: Paz e Terra; 1975.

Freire P. Pedagogia da autonomia: saberes necessários à prática educativa. São Paulo: Paz e Terra; 1996.

Freitas LC. Neotecnicismo e formação do educador. In: Alves N. (org.). Formação de Professores: pensar e fazer. São Paulo: Cortez; 2004.

Gil AC. Como elaborar projetos de pesquisa. $3^{\underline{a}}$ ed. São Paulo: Atlas; 1991. GOVERNO DO ESTADO DE SÃO PAULO. SECRETARIA DO MEIO AMBIENTE. Educação Ambiental e Desenvolvimento: Documentos oficiais. São Paulo: Governo do Estado de São Paulo; 1994. 62 p. (Série Documentos).

Hernandez F. Transgressão e mudança na educação: os projetos de trabalho. Porto Alegre: Artes Médicas; 1998. 
Hobsbawn E. Era dos extremos: o breve século XX (1914-1991). São Paulo: Companhia das Letras; 1995.

IBAMA - Instituto Brasileiro do Meio Ambiente e dos Recursos Naturais Renováveis. Educação Ambiental: as grandes orientações da Conferência de Tbilisi. Brasília; 1997.

IBGE lervolino SA, Pelicioni MCF. A utilização do grupo focal como metodologia qualitativa na promoção de saúde. In: Anais do $50^{\circ}$. Congresso Brasileiro de Enfermagem; 1998 set 20-25/ Salvador; Brasil. p.88.

Jodelet D. Representações Sociais: um domínio em expansão. In: Jodelet D, organizadora. As representações sociais. Rio de Janeiro: UERJ; 2001. p.17-44.

Kidder LH, organizadora. Selltiz, Wrightsman e Cook. Métodos de pequisa social. 2 ${ }^{a}$. ed. São Paulo: EPU; 1987.Medidas na pesquisa social; v.2.

Kohler MCM. Agenda 21 Local: Desafios da sua implementação. Experiências de São Paulo, Rio de Janeiro, Santos e Florianópolis. São Paulo; 2003. [Dissertação de Mestrado - Faculdade de Saúde Pública da Universidade de São Paulo].

Kranz P. Mourão J. Agenda 21: Vitória do futuro. Vitória: Secretaria Municipal de Meio Ambiente; 1997. v.1.

Loureiro CFB. Teoria social e questão ambiental: pressupostos para uma prática crítica em educação ambiental. In: Loureiro CFB, Layrargues PP , Castro RSC (orgs.) Sociedade e meio ambiente: a educação ambiental em debate. São Paulo: Cortez; 2000.

Lüdke M. André M. Pesquisa em Educação: Abordagens Qualitativas. São Paulo: Pedagógica e Universitária Ltda; 1986. 
Manzochi LH, Trajber R. Avaliando a educação ambiental no Brasil: materiais impressos. São Paulo: Gaia; 1996.

Marcon G. Avaliação da Política Estadual de Recursos Hídricos de São Paulo nas Bacias Hidrográficas dos Rios Piracicaba, Capivari e Jundiaí. São Paulo: Universidade de São Paulo. Faculdade de Saúde Pública. Departamento de Saúde Ambiental, 2005 [Tese de Doutorado. Faculdade de Saúde Pública da ESP].

Martins JPS. A década desperdiçada: o Brasil, a Agenda 21 e a Rio+10. Campinas: Komedi; 2002.

McCormick J. Rumo ao paraíso: a história do movimento ambientalista. Rio de Janeiro: Relume-Dumará; 1992.

Minayo MCS. O desafio do conhecimento.6 ed. São Paulo: Hucitec; 2000.

Minayo MCS. Assis SG \& Souza ER (orgs). Avaliação por triangulação de métodos: abordagem de Programas sociais. Rio de Janeiro: Editora Fiocruz; 2005.

[MEC] MINISTÉRIO DE EDUCAÇÃO E CULTURA / [MMA] MINISTÉRIO DO MEIO AMBIENTE. Relatório do Levantamento Nacional de Projetos de Educação Ambiental. I Conferência Brasileira de educação Ambiental. Brasília; 1997. Mimeogr.

[MEC] MINISTÉRIO DE EDUCAÇÃO E CULTURA. Educação Ambiental Legal, 2006. In:http://www.mec.gov.br/se/educacaoambiental/pdf/ealegal.pdf

[MMA] Ministério do Meio Ambiente. Agenda 21: O caso do Brasil. Brasília (DF); 1998.

Morin E, Kern AB. A carta de identidade terrena. In: Revista Margem № 3 Condição Planetária. São Paulo: Faculdade de Ciências Socias - PUC EDUC - 1994. 
Moscovici S. A representação social da psicanálise. Rio de Janeiro: Zahar; 1978.

PNEA-Órgão Gestor/ MMA/MEC. Juventude, cidadania e meio ambiente. Brasília: UNESC; 2006.

Pelicioni AF. Educação Ambiental na escola: um levantamento de percepções e práticas de estudantes de $1^{\circ}$. grau a respeito de meio ambiente e problemas ambientais. São Paulo; 1998. [Dissertação de Mestrado - Faculdade de Saúde Pública da Universidade de São Paulo].

Pelicioni AF. Educação Ambiental limites e possibilidades de uma ação transformadora. São Paulo; 2002. [Tese de Doutorado - Faculdade de Saúde Pública da Universidade de São Paulo].

Pelicioni MCF. Educação em Saúde e Educação Ambiental estratégias de construção da escola promotora da saúde. São Paulo 2000. [Tese de Livre Docência - Faculdade de Saúde Pública da Universidade de São Paulo ].

Pelicioni MCF, Philippi Jr A. Agenda 21 Local instrumento de controle social - Jornal da USP. São Paulo; 1999 mar 4-14 p.2.

Philippi Jr A, Pelicioni MCF. Agenda 21 - o que, por que, pra que ? Jornal da USP. São Paulo, 9 -15 mar 1998.

Philippi Jr A, Pelicioni MCF. Educação Ambiental: desenvolvimento de cursos e projetos. São Paulo: Nisam/Faculdade de Saúde Pública da USP; 2000.

PNUD/IPEA/IBGE. Relatório sobre desenvolvimento humano no Brasil.1996. Brasília: Fundação João Pinheiro; 1998.

[PMJ] Prefeitura do Município de Jundiaí [homepage na Internet] Jundiaí. [atualizado em 18 maio 2006; acesso em 21 maio de 2006].

Reigota M. Meio Ambiente e representação social. São Paulo: Cortez; 1995. 
Reigota M. Ecologia, elites e inteligentsia na América latina: um estudo de suas representações sociais. São Paulo: Annablume; 1999a.

Reigota M. A Escola e a Floresta: por uma educação ambiental pós moderna . São Paulo: Cortez; 1999b.

Reigota M. La transversalidad en Brasil: una banalización neoconservadora de una propuesta pedagógica radical. In: Tópicos en Educación Ambiental 2 (6), 19-26 (2000).

Reigota M. Compromlsso político e competência técnica. In: Philippi Jr A,

Pelicioni MCF (editores). Educação ambiental: desenvolvimento de cursos e projetos. $2^{\mathrm{a}}$ ed. São Paulo. Faculdade de Saúde Pública. NISAM: Signus, 2002. p. 33-35.

Santos M. Por uma Geografia Nova: Da Crítica da Geografia a uma Geografia Crítica. 6.ed. São Paulo: Editora da Universidade de São Paulo; 2004.

Santos BS. Pela mão de Alice: o social e o político na pós-modernidade. 10 ed. São Paulo: Cortez; 2005.

SEE/CENP. Água hoje e sempre : consumo sustentável. São Paulo: SE/CENP; 2004.

SMA/CPLEA. Educação Ambiental: vinte anos de políticas públicas. São Paulo: SMA; 2003.

TOLEDO RF. Educação Ambiental em Unidades de Conservação do Estado de São Paulo. São Paulo 2002. [Dissertação de Mestrado - Faculdade de Saúde Pública da Universidade de São Paulo].

UNESCO. Educação para um futuro sustentável: uma visão transdisciplinar para ações compartilhadas. Brasília: Ed. IBAMA; 1999. 
UNESCO - UNEP. The Belagrade Chardter. Connect 1976; 1(1):69-77.

UNESCO - UNEP. The Tbilisi Declaration. . Connect 1978; 3(1):1-8.

[WMO] World Meteorological Organizacion. The Dublin Statement on Water and Sustainable Development [on line]. 1992. Available from URL<htpp://www.wmo.ch/web/homs/documents/english/icwedece.html\#p1>[ 2006 Jun 21]. 
ANEXO 1. ESCOLAS ESTADUAIS DO MUNICÍPIO DE JUNDIAÍ

\begin{tabular}{|c|c|c|c|}
\hline & Escola & Bairro & $\begin{array}{l}\text { № de } \\
\text { Professores } \\
\text { Participantes }\end{array}$ \\
\hline 1 & Adib Miguel Haddad & Jd S Gertrudes & 11 \\
\hline 2 & Adoniro Ladeira Prof. & Jd Shangai & 2 \\
\hline 3 & Albertina Fortarel Profa & $\begin{array}{l}\text { Prq Res A. } \\
\text { Chaves }\end{array}$ & 12 \\
\hline 4 & Albino Melo De Oliveira Prof & VI Marlene & 1 \\
\hline 5 & Ana Pinto Duarte Paes Profa & Ponte Sao Joao & 7 \\
\hline 6 & Antenor Soares Gandra Dr & Centro & 11 \\
\hline 7 & Barao De Jundiai & Jd S C Jesus & 8 \\
\hline 8 & Benedicto Loschi & Corrupira & 3 \\
\hline 9 & Benedita Arruda Profa & VI Didi & 6 \\
\hline 10 & $\begin{array}{l}\text { Cecilia Rolemberg Porto Guelli } \\
\text { Profa }\end{array}$ & VI R Branco & 6 \\
\hline 11 & Conde do Parnaiba & Centro & 6 \\
\hline 12 & $\begin{array}{l}\text { Deolinda Copelli De S. Lima } \\
\text { Profa. }\end{array}$ & VI R Barbosa & 6 \\
\hline 13 & Diogenes Duarte Paes & Prq Brasilia & 6 \\
\hline 14 & Eloy De Miranda Chaves Dr & Jd B Vista & 7 \\
\hline 15 & Francisco Napoleao Maia Prof & VI Salermo & 8 \\
\hline 16 & $\begin{array}{l}\text { Gabriel Paulino B. Couto Bispo } \\
\text { Dom }\end{array}$ & VI Virginia & 2 \\
\hline 17 & Getulio Nogueira De Sa Prof & Jd V Cruz & 15 \\
\hline 18 & Joao Batista Curado Prof & Jd Taruma & 10 \\
\hline 19 & Joao Luiz Campos Prof & Jd Florestal & 2 \\
\hline 20 & Joceny Villela Curado Profa & VI Comercial & 8 \\
\hline 21 & Jose Feliciano De Oliveira Prof & Jd Tamoio & 7 \\
\hline 22 & Jose Silva Junior Prof & Jd Bandeiras & 8 \\
\hline 23 & Jurandyr De Souza Lima & Traviu & - \\
\hline 24 & Luiz Rivelli Prof & VI Marlene & 2 \\
\hline 25 & $\begin{array}{l}\text { Maria De Almeida Schledorn } \\
\text { Profa }\end{array}$ & Jd Tulipas & 9 \\
\hline 26 & Maria de L. F. Silveira Profa & Jd Pacaembu & 9 \\
\hline 27 & Maria Jose Maia De Toledo Profa & Jd S C Novo & 17 \\
\hline 28 & Maurilio Tomanik Padre & Prq Cecap & 25 \\
\hline 29 & Orozimbo Sostena Prof & Jd Estadio & 2 \\
\hline 30 & Parque Res. Almerinda Chaves & Alm. Chaves & 7 \\
\hline
\end{tabular}




\begin{tabular}{|l|l|l|c|}
\hline 31 & Paulo Mendes Silva & VI Arens li & 7 \\
\hline 32 & Rafael De Oliveira & Planalto & 2 \\
\hline 33 & Rafael Mauro Dr & VI Maringa & 4 \\
\hline 34 & Ranieri Mazzilli Deputado & VI Esperanca & - \\
\hline 35 & Siqueira de Moraes Cel & VI Vianelo & 9 \\
\hline 36 & Venerando Nalini Monsenhor & Ivoturucaia & 10 \\
\hline
\end{tabular}


ANEXO 2. ESCOLAS ESTADUAIS DO MUNICÍPIO DE LOUVEIRA

\begin{tabular}{|c|l|c|c|}
\hline \multicolumn{1}{|c|}{} & \multicolumn{1}{|c|}{ Escola } & Bairro & $\begin{array}{l}\text { Professores } \\
\text { Participantes }\end{array}$ \\
\hline 1 & Alberto Ferreira Rezende Prof & Sto Antonio & 7 \\
\hline 2 & Joaquim Antonio Ladeira Prof & Vila Bossi & 6 \\
\hline 3 & Odilon Leite Ferraz & Santo Antonio & 7 \\
\hline 4 & Pedro Yoshichika Irie & Leitao & 6 \\
\hline
\end{tabular}




\section{ANEXO 3. ROTEIRO PARA GRUPO FOCAL}

1. A sua escola tem realizado trabalhos voltados para a temática ambiental?

2. Se sim, quais ?

3. Se a escola não realiza trabalhos com a temática ambiental, qual, ou, quais os motivos que impedem que isso aconteça?

4. Quem costuma definir o trabalho a ser desenvolvido na sua escola ?

5. Existe um planejamento anterior?

6. Você se sente capacitado para desenvolver temas relacionados a meio ambiente?

7. Na sua opinião a escola seria um local adequado para a implantação da Agenda 21?

8. O que você acha da Agenda 21 como estratégia de ensino na escola ?

9. Existe material disponível sobre Agenda 21 na sua escola ?

10. Em que medida a Oficina Pedagógica pode dar subsídios para o seu trabalho? 


\title{
ANEXO 4. TERMO DE CONSENTIMENTO LIVRE E ESCLARECIDO - GRUPO FOCAL
}

\author{
PESQUISA: ESTUDO DO PROCESSO DE CONSTRUÇÃO DA AGENDA \\ 21 NAS ESCOLAS DA DIRETORIA DE ENSINO DE JUNDIAI - SP.
}

PESQUISADORA: Claudete Aparecida Formis, professora efetiva da Secretaria da Educação do Estado de São Paulo.

OBJETIVO: Analisar e descrever o processo de implantação da Agenda 21 em determinadas escolas da Rede Estadual de Ensino, no município de Jundiaí, a partir da proposta pedagógica da CENP, orientando o trabalho dos professores a partir da temática principal "Água Hoje e Sempre: Consumo Sustentável".

PROCEDIMENTOS: Coleta de dados por meio da técnica de grupo focal com professores nas escolas.

* Será garantido o anonimato do(a) participante.

*A pesquisadora se compromete a esclarecer todas as dúvidas acerca da pesquisa, assim como a divulgar os resultados após o término da mesma.

$\mathrm{Eu}$,

Professor (a) da Escola Estadual

$R G$

aceito fazer parte do grupo de pesquisa para a qual fui convidado(a), participando das atividades do grupo focal para a elaboração do Projeto Agenda 21 na Escola.

Autorizo a utilização das informações fornecidas, e estou ciente de que, com a minha autorização, a reunião será gravada.

Sei que minha participação é livre, não obrigatória, podendo ser interrompida por minha decisão a qualquer momento, sem qualquer prejuízo.

Assinatura do Professor

Assinatura do pesquisador

Maiores informações: Claudete Aparecida Formis e Profa. Dra. Maria Cecília Focesi Pelicioni

Departamento de Prática de Saúde Pública - Faculdade de Saúde Pública da Universidade de São Paulo. Av. Dr. Arnaldo, 715. Telefones : (11) 3066.7761 ou (11) 4607.6706 . 


\title{
ANEXO 5. TERMO DE CONSENTIMENTO LIVRE E ESCLARECIDO - DOCUMENTOS
}

\author{
PESQUISA: ESTUDO DO PROCESSO DE CONSTRUÇÃO DA AGENDA \\ 21 NAS ESCOLAS DA DIRETORIA DE ENSINO DE JUNDIAI - SP.
}

PESQUISADORA: Claudete Aparecida Formis, professora efetiva da Secretaria da Educação do Estado de São Paulo.

OBJETIVO: Analisar e descrever o processo de implantação da Agenda 21 em determinadas escolas da Rede Estadual de Ensino, no município de Jundiaí, a partir da proposta pedagógica da CENP, orientando o trabalho dos professores a partir da temática principal "Água Hoje e Sempre: Consumo Sustentável”.

PROCEDIMENTOS: Análise do material produzido ou apresentado pelos professores nas reuniões da Oficina Pedagógica da Diretoria de Ensino de Jundiaí.

* Será garantido o anonimato do(a) autor(a) do material.

* A pesquisadora se compromete a esclarecer todas as dúvidas acerca da *pesquisa, assim como a divulgar os resultados após o término da mesma.

$\mathrm{Eu}$, professor (a) da Escola Estadual $R G$ aceito fazer parte do grupo para o qual fui convidado(a), participando das reuniões de Orientações Técnicas da Oficina Pedagógica, da Diretoria de Ensino de Jundiaí, incluindo a produção de material didático, cursos de capacitação, seminários, encontros, conferências e discussões para a elaboração do Projeto Agenda 21 na Escola .

Autorizo a utilização do produto destas reuniões e dos documentos aí gerados ou apresentados para análise e divulgação no projeto acima citado.

Sei que minha participação e a dos alunos é livre, não obrigatória, podendo ser interrompida por minha decisão a qualquer momento, sem qualquer prejuízo.

\section{Assinatura do Professor Assinatura do pesquisador}

Maiores informações: Claudete Aparecida Formis e Profa. Dra. Maria Cecília Focesi Pelicioni

Departamento de Prática de Saúde Pública - Faculdade de Saúde Pública da Universidade de São Paulo. Av. Dr. Arnaldo, 715. Telefones : (11) 3066.7761 ou (11) 4607.6706 . 
ANEXO 6 - FOTOS DA EXPOSIÇÃO -1ำ EMESA (Encontro Municipal de Educação e Sustentabilidade Ambiental) - LOUVEIRA

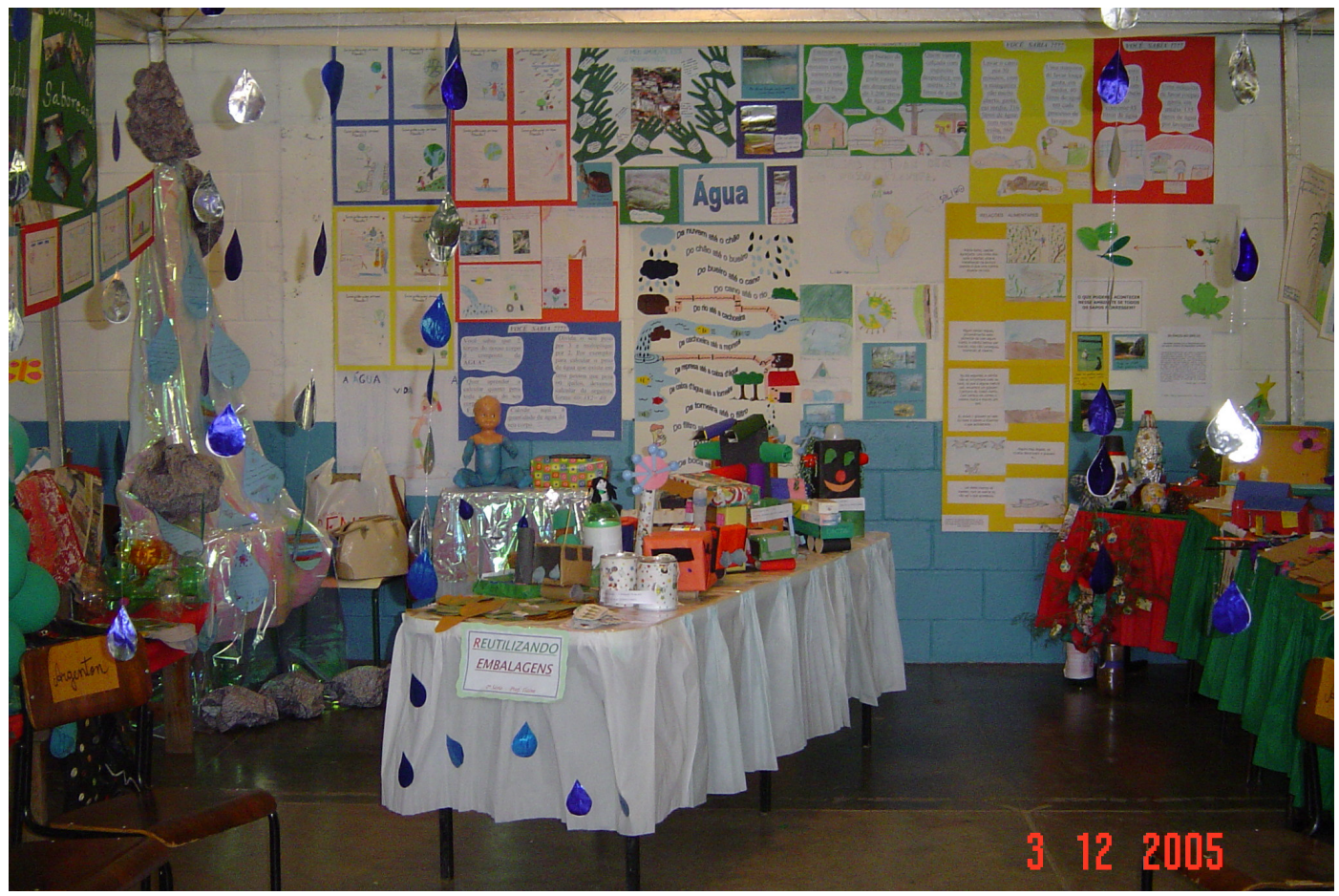

Participação das escolas de $1^{\mathrm{a}}$ a $4^{\mathrm{a}}$ séries.

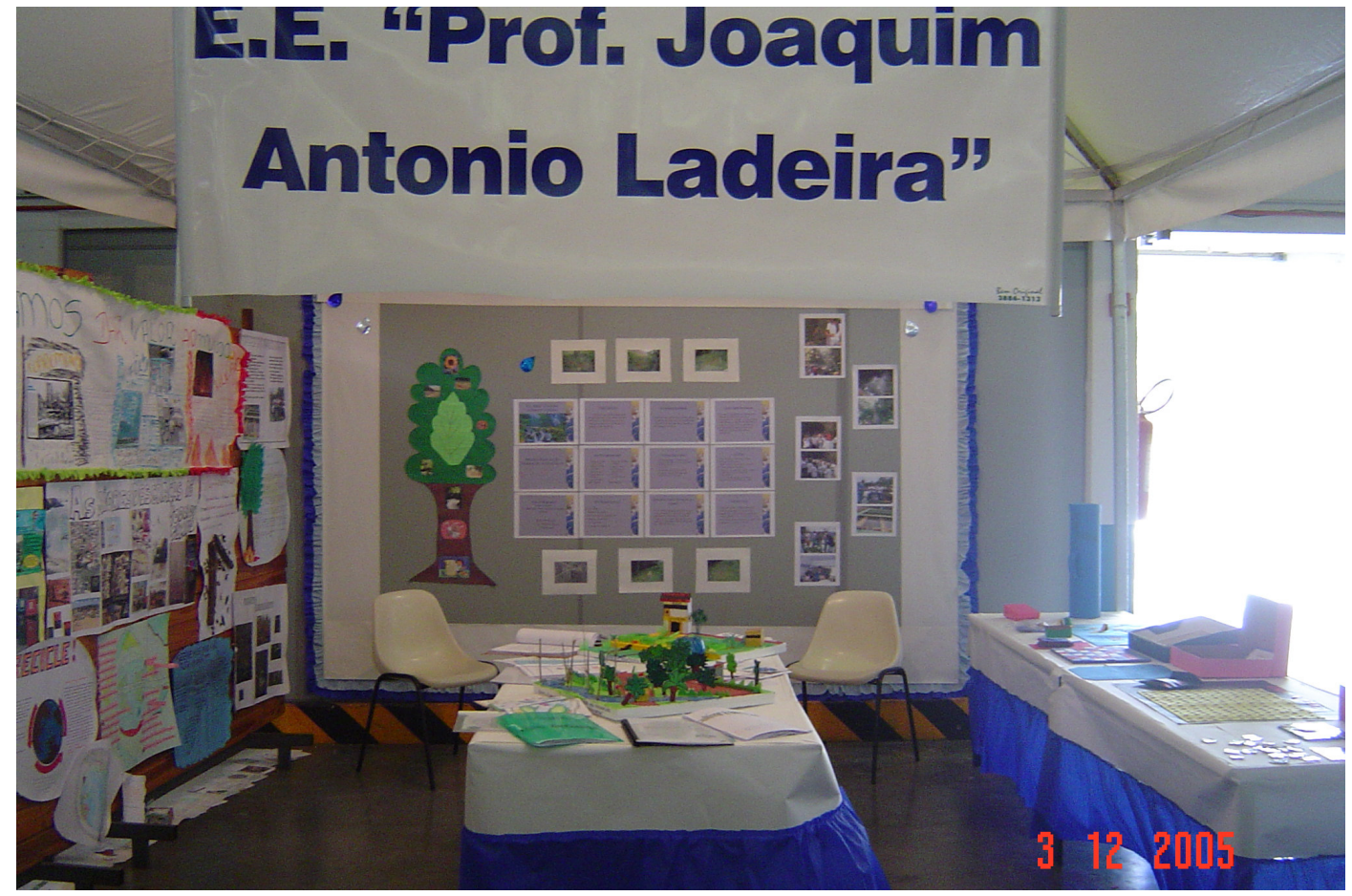


ANEXO 7 - FOTOS DA EXPOSIÇÃO -1ํㅡㄹ EMESA (Encontro Municipal de Educação e Sustentabilidade Ambiental) - LOUVEIRA

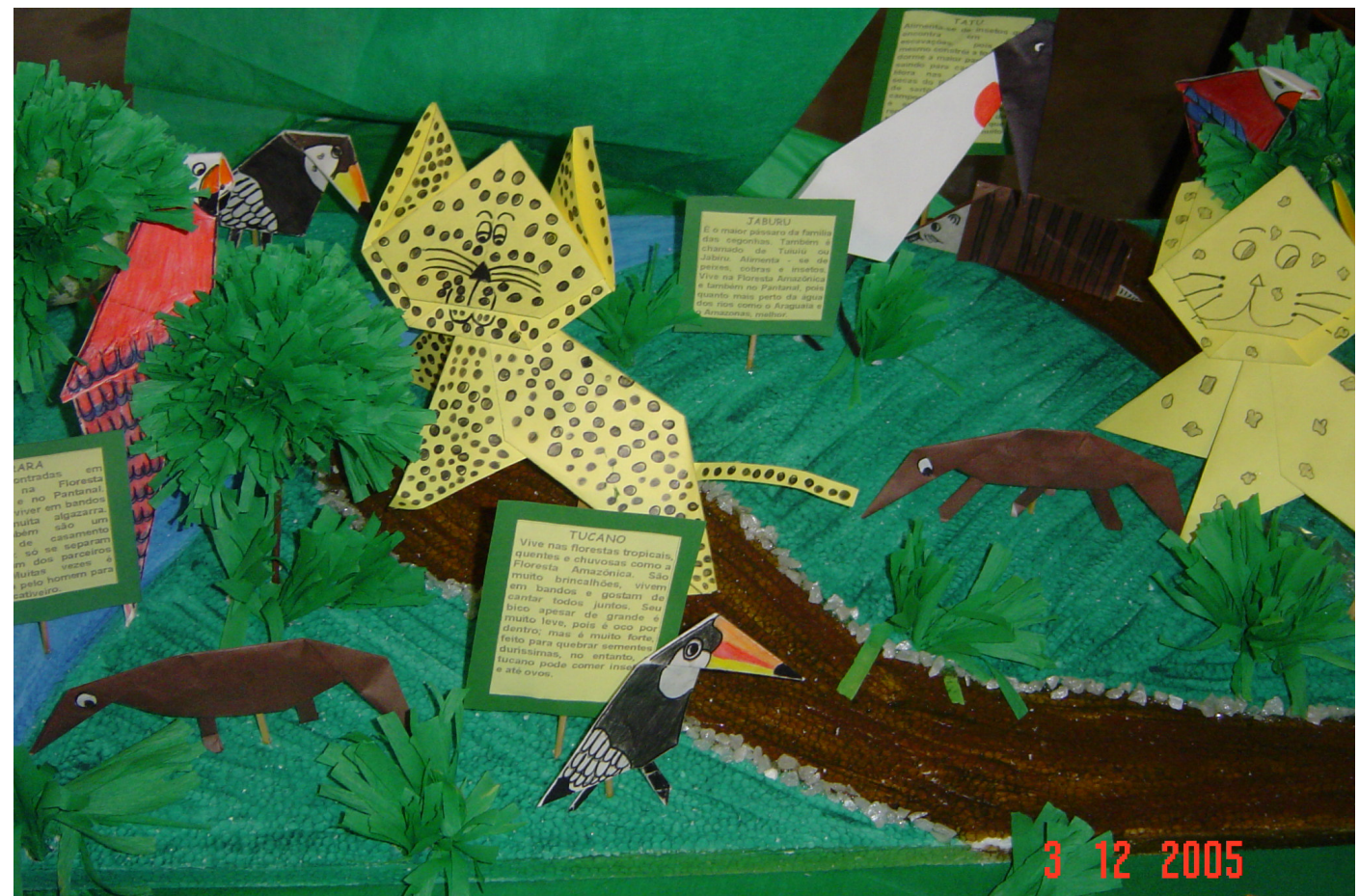

Participação das escolas de $1^{\mathrm{a}}$ a $4^{\mathrm{a}}$ séries.

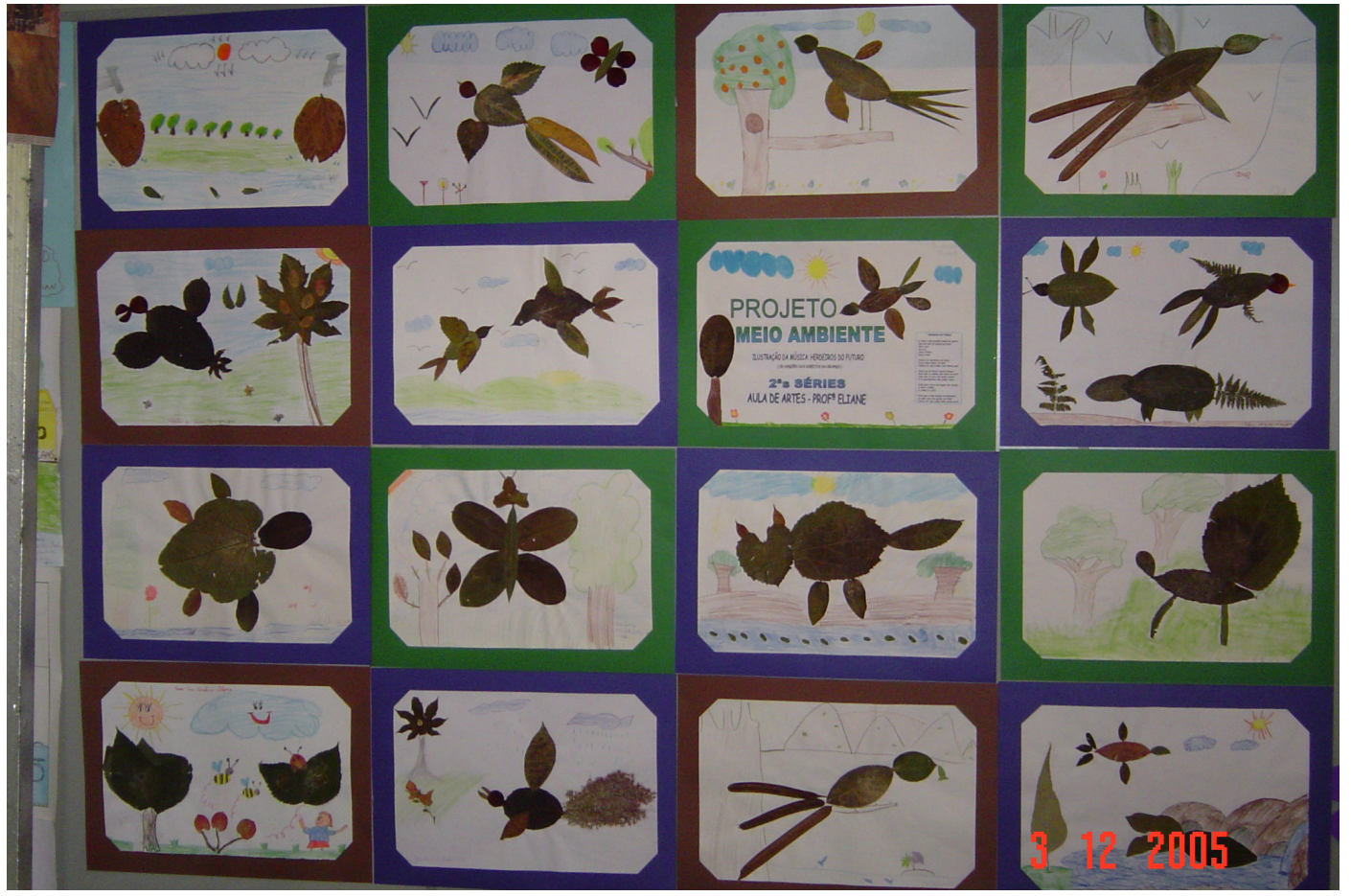


ANEXO 8 - MAPA DA ÁREA DE ESTUDO: REGIÃO DE JUNDIAÍ -SP

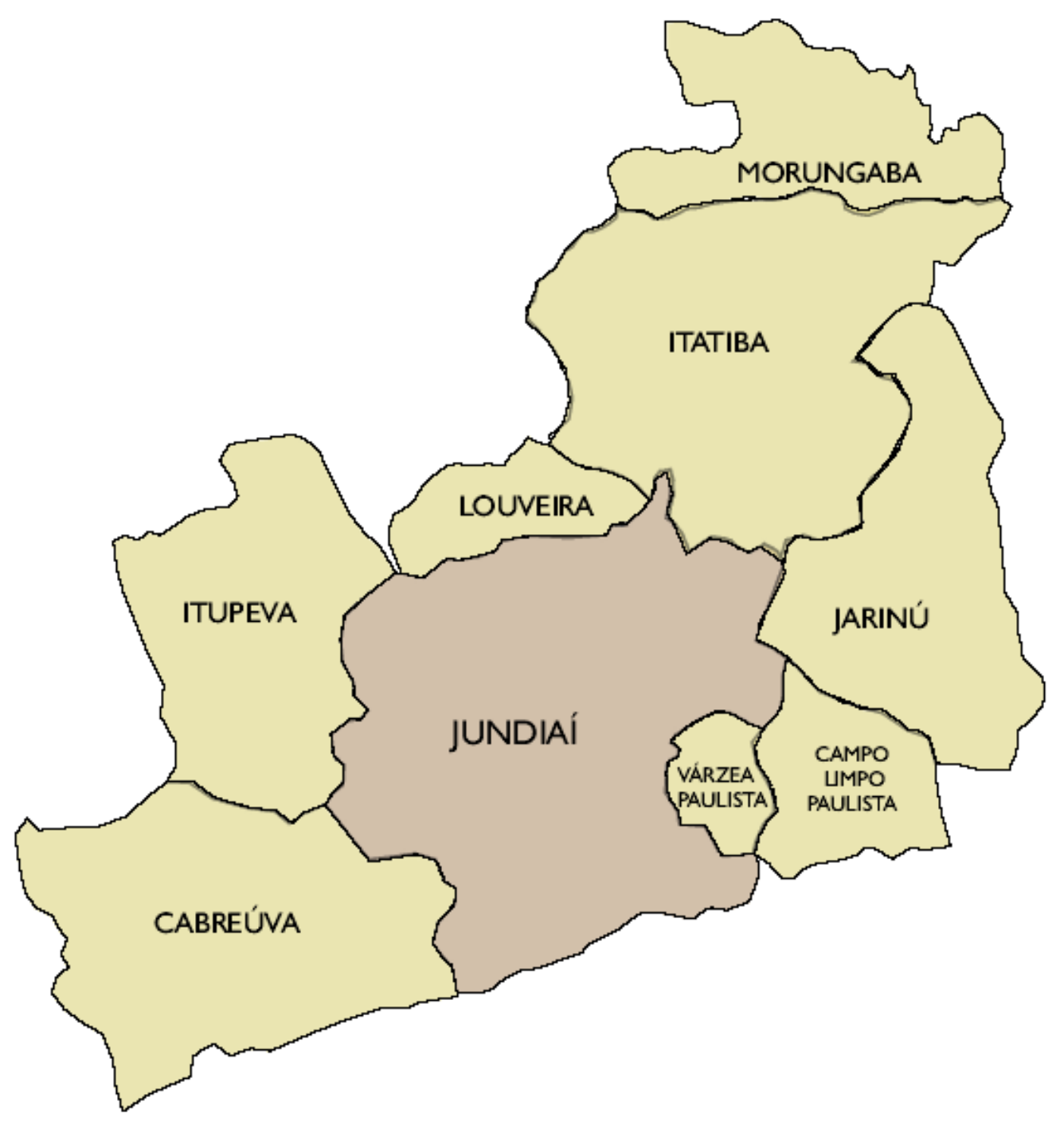

